\section{BunuAnR PSiklkologi
RORSCHACH}

(Pengantar dan Manual Pengguna)

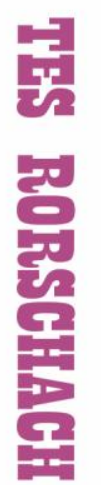

Digunakan selagai pegangan mahasiswa mata kuliah tes Rarschach

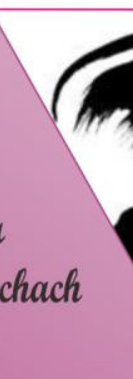

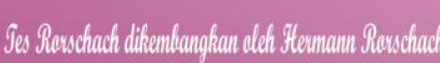

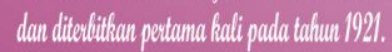

Ses Serschach mengenguakaun berack titita

seluagai alat tes

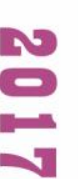

\section{)}
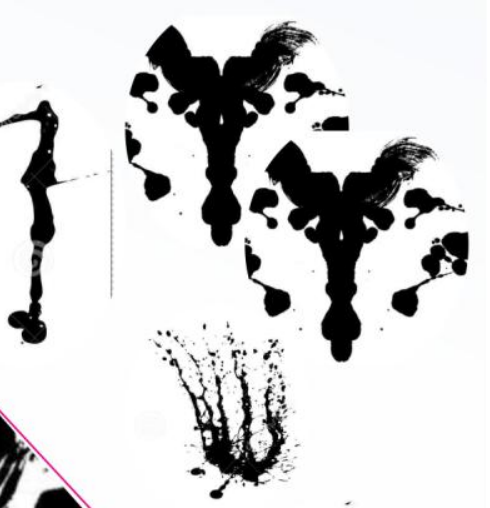

1 


\title{
BUKU AJAR \\ TES RORSCHACH \\ (Pengantar dan Manual Pengguna)
}

\section{Penulis}

Dra. Dwi Nastiti, M.Si.

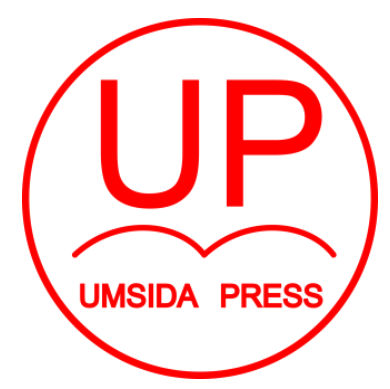

\author{
Diterbitkan oleh \\ UMSIDA PRESS \\ J1. Mojopahit 666 B Sidoarjo \\ ISBN: 978-979-3401-58-4
}

Copyright@2017.

Authors

All rights reserved 
BUKU AJAR

\section{TES RORSCHACH}

(Pengantar dan Manual Pengguna)

\section{Penulis :}

Dra. Dwi Nastiti, M.Si.

\section{ISBN :}

978-979-3401-58-4

\section{Editor :}

Septi Budi Sartika, M.Pd

M. Tanzil Multazam, S.H., M.Kn.

\section{Copy Editor :}

Fika Megawati, S.Pd., M.Pd.

Design Sampul dan Tata Letak :

Mochamad Nashrullah, S.Pd

\section{Penerbit :}

UMSIDA Press

\section{Redaksi :}

Universitas Muhammadiyah Sidoarjo

J1. Mojopahit No 666B

Sidoarjo, Jawa TImur

\section{Cetakan pertama, Agustus 2017}

(C) Hak cipta dilindungi undang-undang

Dilarang memperbanyak karya tulis ini dengan suatu apapun tanpa ijin tertulis dari penerbit. 


\section{KATA PENGANTAR}

Dalam proses belajar mengajar sarana pendukung sangat dibutuhkan, terutama bagi mahasiswa, didalam usaha untuk lebih mudah memahami materi yang ingin dikuasainya.

Di Fakultas Psikologi, ada beberapa mata kuliah yang mengharuskan mahasiswa melakukan praktikum, yaitu pada mata kuliah psikodiagnostik, salah satunya adalah Tes Rorschach. Sarana pendukung selain alat tes juga dibutuhkan materi tentang alat tes tersebut dalam bentuk buku ajar yang berisikan pengantar dan manual bagi pengguna alat tes tersebut. Oleh karena itu, keberadaan buku ini sangat dibutuhkan bagi siapa saja yang ingin mengetahui tentang tes psikologi (terutama mahasiswa) mengingat dalam pelaksanaan praktikumnya mengandung tahapan-tahapan yang harus betul betul dipahami dan bisa dengan mudah dan benar dipraktekkan oleh mahasiswa.

Buku tentang Tes Rorschach yang berbahasa Indonesia tidak tersedia di luar, karena disusun hanya untuk konsumsi mahasiswa S-1 yang ingin mempelajarinya sesuai kurikulum Program Studi. Penulis berusaha menyusunnya untuk untuk memenuhi kebutuhan tersebut. Tentu saja tulisan ini jauh dari sempurna, untuk itu kritik dan saran sangat 
dibutuhkan penulis guna penyempurnaan kekurangankekurangan yang ada.

Mudah-mudahan, dengan perkenan Allah SWT, buku materi tentang Tes Rorschach bisa diterima, dan memberi manfaat dan kebaikan bagi siapa saja yang membutuhkan.

Surabaya, Maret 2017

Penulis 


\section{DAFTAR ISI}

KATA PENGANTAR ...................................................... ii

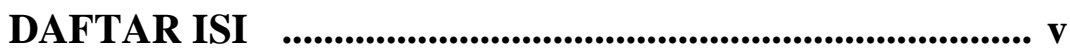
BAB I : PENDAHULUAN

I.1. Tes Rorschach : Tes Dengan Teknik Proyektif ...................................................... 2

I.2. Kelebihan Tes Rorschach ..............................6

I.3. Aplikasi Tes Rorschach dalam asesmen

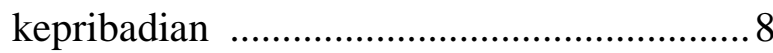

\section{BAB II : KONSEP, TEORI, ASPEK KEPRIBADIAN DARI TES RORSCHACH}

II.1 Konsep Dasar Tentang Tes Rorschach..... 17

II.2. Teori Kepribadian Yang Mendasari Tes Rorschach .............................................21

II.3. Aspek Kepribadian Yang Tergali Dari Tes Rorschach ........................................... 25

\section{BAB III : PENGENALAN ALAT TES}

III.1 Sejarah Perkembangan Tes 36

III.2 VALIDITAS dan RELIABILITAS TES RORSCHACH 46

III.3 Kartu-Kartu Tes Rorschach .50 III.4 Karakteristik Kartu-Kartu Tes Rorschach.51

\section{BAB IV : ADMINSITRASI TES RORSCHACH}

IV.1 Persiapan Tes 69

IV.2. Tahap Pelaksanan Tes Rorschach 73

Tahap I : Performance Proper 
Tahap II : Inquiry

Tahap III : Analogy ...............................85

Tahap IV : Testing The Limit ................86

\section{BAB V : SKORING HASIL TES RORSCHACH}

V.1. Jenis Respon …………………….........93

V.2. Skoring ……............................................97

\section{BAB VI : TABULASI HASIL TES RORSCHACH}

VI.A Tabulation And Scoring Sheet ............... 175

VI.B Psikogram .......................................... 181

VI.C Relationships among Factors …........... 182

VI.D Manner Of Approach ........................... 186

VI.E Suksesi .................................................. 187

VI.F Form-Level Rating ................................ 188

\section{BAB VII : INTERPRETASI TES RORSCHACH}

VII.1. Interpretative Meaning Of The Categori

Scoring ….............................................. 192
A. Skor Lokasi
193
B. Skor Determinant .........................208
C. Skor Content ...............................255
D. Skor Populer - Original (P-O) 271
E. Skor FLR .....................................2273
F. Skor Additional ….........................2274

VII.2. Interpretasi Untuk Proporsi Kuantitatif 274

A. Proporsi yang berkaitan dengan Inner Resource dan Impuls Life ............ 275 
B. Proporsi Yang Berkaitan Dengan Responsivitas mosional Terhadap Lingkungan .......................................2278

C. Proporsi yang berkaitan dengan Keseimbangan Introversive Extratensive .281

D. Proporsi yang berkaitan dengan Pengorganisasian KebutuhanKebutuhan Afeksi ............................2284

E. Proporsi yang berkaitan dengan Minat Intelektual dan Ambisi 286

F. Proporsi yang berkaitan dengan Kontrol dalam Keadaan terdesak (Constrictive - Control) ................... 289

G. Evaluasi terhadap Kontrol, PotensiPotensi Dalam (Inner Resources), Pendekatan Intelektual Dan Level Intelektual 291

H. Analisa Urutan (Sequence Analysis)304

I. Content Analysis (Analisa Isi) …....310 


\section{BAB I \\ PENDAHULUAN}

\section{Kemampuan Akhir Yang Direncanakan :}

Setelah mempelajari bab ini, diharapkan mahasiswa mampu memahami kedudukan Tes Rorschach dalam tes proyeksi secara global, serta mengetahui aplikasinya dalam asesmen kepribadian di berbagai bidang.

Psikologi adalah ilmu yang berusaha memahami perilaku manusia. Usaha untuk memahaminya bisa dilakukan dengan menggunakan asesmen psikologi, dan salah satunya adalah dengan menggunakan tes psikologi.

Tes psikologi disusun dengan tujuan khusus, seperti pengukuran dengan tujuan untuk mengetahui potensi intelektual, bakat, minat, kepribadian, dan aspek psikologis lainnya. 
Tes psikologi yang digunakan untuk mengukur kepribadian disusun dengan menggunakan teknik proyektif. Ada yang berbentuk inventory, atau berbentuk gambar, tapi tetap memiliki tujuan yang sama. Beberapa tes gambar yang paling sering digunakan adalah Tes Rorschach, TAT, jugaWartegg.

Di sini akan dibahas salah satu bentuk tes kepribadian dalam bentuk gambar, yaitu Tes Rorschach.

\section{I.1. Tes Rorschach : Tes Dengan Teknik Proyektif}

Tes psikologi yang digunakan untuk mengetahui kepribadian seseorang dikenal dengan tes psikologi dengan teknik proyektif. Tes dengan teknik proyektif dimaksudkan untuk mengukur atau mengetahuan kepribadian seseorang dengan menggunakan teknik proyektif. Pengertian teknik proyektif dalam pemeriksaan kepribadian adalah merupakan teknik pencerminan keunikan kepribadian individu lewat bagaimana seseorang menanggapi suatu stimulus yang ambigius, yaitu stimulus yang sifatnya kabur, tidak terstruktur, atau tidak mempunyai makna yang pasti, karena bisa bermakna ganda (Abt \& Bellak, 1959). 
Secara garis besar tes-tes proyektif dapat dipilah menjadi 2 (dua) kelompok :

\section{Tes Proyektif Verbal}

Tes proyektif yang materinya maupun reaksi subyek dan instruksinya menggunakan bahasa, sehingga dalam tes ini dituntut kemampuan bahasa subyek yang dites. Ada beberapa tes yang termasuk kelompok ini, diantaranya : EEPS, SSCT, MMPI, 16 PF, Kuder, Study of Value.

2. Tes Proyektif Non Verbal

Tes proyektif yang memakai bahasa hanya instruksinya saja, tetapi stimulusnya bisa berupa gambar cerita, bercak tinta, atau goresan tangan. Kemampuan bahasa subyek didalam mereaksi rangsang yang disajikan tidak dituntut.

Tes jenis non verbal ini ternyata lebih luas penggunaannya, karena dapat dikenakan pada hampir setiap orang.

Beberapa tes yang bisa dimasukkan ke dalam kelompok ini yaitu : TAT, Rorschach, Tes Grafis, Tes Wartegg.

Dengan demikian bisa dilihat bahwa dalam penggolongannya, Tes Rorschach merupakan cara / 
prosedur untuk mengungkapkan kepribadian individu dengan menggunakan teknik proyektif non verbal, yaitu tes proyektif yang hanya instruksinya saja yang memakai bahasa, tetapi stimulusnya bisa berupa gambar cerita, bercak tinta, atau goresan tangan. Pada Tes Rorschach, stimulusnya berupa bercak tinta.

Di antara jajaran tes proyeksi non verbal, tes Rorschach menempati jenjang pertama, artinya merupakan tes dengan teknik proyektif yang paling populer dan diikuti TAT. Oleh karena itu, beberapa ahli menyarankan untuk menggunakan kedua jenis tes ini (Rorschach dan TAT) untuk mengungkap kepribadian secara lengkap (Anastasi \& Urbina, 2007).

Seperti halnya tes kepribadian lainnya, tes Rorschach dituntut mampu memahami kepribadian secara tepat. Ketepatan didalam memahami gambaran kepribadian seseorang memang harus dikontrol dengan cara memberikan battery test, artinya selain memberi tes Rorschach, kita juga harus memberi tes lain sebagai pengontrol, contohnya : dengan menggunakan tes Rorschach kita bisa mengungkap potensi intelektual seseorang, tetapi akan lebih bisa mengungkap bila 
dikombinasi dengan tes Intelegensi (terutama untuk mengungkap aspek kognitif / intelektualnya), karena hasil aspek kognitif lebih baik gambarannya bila menggunakan tes intelegensi sendiri. Hal ini sesuai dengan pendapat Abt \& Bellak (1959), bahwa tidak ada tes proyeksi tunggal yang dianggap dapat "mengukur" kepribadian secara total dan tidak ada "inventory kepribadian non-proyektif" yang dapat dianggap sebagai penilai kepribadian, termasuk kekayaan organisasi dan differensiasinya sebagai suatu proses.

Kesimpulan yang didapat dari suatu tes kepribadian, termasuk Tes Rorschach, hanya merupakan predisposisi kepribadian dari orang yang bersangkutan. Predisposisi adalah kecenderungan khusus ke arah suatu keadaan atau per-kembangan tertentu. Dengan demikian, bila terjadi perubahan maka akan bisa menghasilkan hal-hal yang lain, misal : dari psikotes diketahui kecerdasannya superior, ternyata di ujian penerimaan mahasiswa baru tidak diterima. Dalam hal ini, hasil suatu psikotes tidak bisa disalahkan karena dari tes hanya bisa dikatahui potensinya saja. 


\section{I.2. Kelebihan Tes Rorschach}

Sebagai tes kepribadian, stimulus dalam bentuk bercak tinta dari tes Rorschach memiliki kelebihan utama. Kelebihan ini berdasar pada asumsi yang mendasari teknik rorschach yaitu adanya relationship antara persepsi dengan kepribadian. Kelebihan yang dimiliki tes Rorschach yaitu :

1. Mengetahui "kepribadian tersembunyi" seseorang.

$\rightarrow$ Hasil persepsi subyek terhadap gambar pada kartukartu Rorschach mengungkap private world (disini subyek tanpa sadar sebenarnya menceritakan pribadinya ) misal :

a) Dalam kehidupan sehari-hari, individu cenderung menolak untuk membentuk relasi dengan orang di sekitarnya, karena mereka tidak menyenangkan dan menyebabkan individu tersebut merasa tidak tenang atau gelisah.

Pada kartu Rorschach, bisa tampak pada respon-respon dimana individu menolak melihat orang / manusia, individu benar-benar tidak melihat / menangkap figur manusia pada gambar-gambar Rorschach. Individu cenderung 
malah melihat yang lain, seperti tumbuhtumbuhan, gunung-gunung dengan awannya, dsb.

b) Dalam kehidupan sehari-hari , individu tidak mau menghadapi sumber permasalahan, melainkan hanya nyrempet saja.

Pada kartu Rorschach, individu hanya akan cenderung menaruh perhatian pada daerahdaerah pinggir dari gambar-gambar di kartu Rorschach. Individu hanya akan memperhatikan bagian-bagian kecil sekali dari gambar-gambar di kartu Rorschach.

2. Mengetahui fantasi atau imajinasi yang timbul dalam pikiran seseorang serta interaksinya dengan lingkungan.

$\rightarrow$ a) Dalam kehidupan sehari-hari, jika individu jarang bergaul dengan orang lain.

Pada kartu Rorschach, individu kemungkinan akan jarang menyebutkan sosok-sosok manusia dalam pengamatannya, tetapi lebih banyak menyebutkan benda-benda tak hidup. 
b) Dalam kehidupan sehari-hari, jika individu lebih suka menonton dari-pada melibatkan diri dalam suatu masalah.

Pada kartu Rorschach, individu akan lebih memberi perhatian pada bagian-bagian pinggir bercak tinta di kartu Rorschach.

\section{I.3 Aplikasi Tes Rorschach dalam asesmen kepribadian}

Seperti dijelaskan di atas, Tes Rorschach merupakan salah satu tes psikologi yang digunakan untuk mengetahui gambaran kepribadian seseorang. Lebih jauh, Tes Rorschach bisa digunakan di berbagai situasi dengan tujuan berbeda, baik sebagai usaha untuk penanganan kasus, juga untuk pengembangan ilmu lewat penelitian. Ada beberapa penelitian yang mencoba mengaplikasi tes Rorschach untuk mendapat gambaran kepribadian individu.

a. Di bidang klinis

Di bidang ini, tes Rorschach banyak digunakan untuk mengetahui apakah seorang klien mengalami gangguan atau tidak, apa jenis gangguannya, seperti yang dilakukan para klinikus di awal penggunaan tes Rorschach (Klopfer, 1956). Penerapan tes Rorschach 
sebagian besar di bidang klinis, baik di rumah sakit maupun di klinik psikiatris dan psikologis, misal : tes Rorschach digunakan sebagai terapi, yaitu sebagai sarana yang bisa membuat klien merasa lega dan hilang beban pikiran dan emosionalnya setelah diberi tes Rorschach.

Penggunaan tes Rorschach bisa juga digunakan dalam rangka penelitian untuk memperoleh gambaran gangguan psikologis yang dialami seorang, seperti Retno E.D dan Sarwono, W.S. (2008), yang meneliti tentang Profil Kepribadian Pria Pedofilia Melalui Tes Rorschach. Penelitian ini dilakukan karena melihat semakin seringnya terjadi kekerasan seksual pada anakanak. Tujuan penelitian adalah untuk melihat profil kepribadian 2 pelaku pedofilia melalui tes Rorschach untuk mengungkap aspek kepribadian, meliputi aspek kognitif, afektif, dan fungsi ego. Gambaran subyek : (a) Y dan YG terlihat gelisah, cemas dan merasa tidak aman serta menyembunyikan sesuatu (hasil observasi); (b) Y dan YG sama-sama yaitu: keduanya dapat diklasifikasikan sebagai preferential child molester, mempunyai pengalaman dilecehkan secara seksual saat masih anak-anak, mengalami kesulitan dalam 
mengontrol impuls seksual, mengalami kesulitan dalam hubungan interpersonal, memiliki pribadi yang kurang matang, merupakan individu yang introvert, mengalami kecemasan, dan memiliki kecenderungan depresi. Sedangkan, untuk klasifikasi jenis pedofilia, Y termasuk pedofilia regresi, sedangkan YG adalah pedofilia fiksasi. Temuan pada penelitian ini mengindikasikan adanya permasalahan berupa kecenderungan menjadi homoseksual atau biseksual pada subyek YG.

b. Di bidang pendidikan (di sekolah)

Penggunaan Tes Rorschach bisa membantu guru mengapa seorang peserta didik tidak dapat membaca, menjadi pemalu di dalam kelas dan tidak pernah bermain di halaman, atau memahami mengapa seorang peserta didik menunjukkan perilaku yang sangat agresif.

Pemahaman yang diperoleh guru bisa digunakan untuk mengarahkan bagaimana mengubah atau menangani peserta didik yang bermasalah. Hal ini pernah dilakukan oleh penulis, antara lain pada tahun 2016, saat diminta melakukan asesmen pada siswa 
SMA (menggunakan Tes Rorschach) untuk mengetahui kondisi riil dan masalah apa yang sedang dialami. Keluhan yang disampaikan mengarah pada subyek yang dianggap sering melakukan tindakan yang dianggap aneh oleh teman-temannya, sempat dianggap indigo. Hasilnya, menunjukkan bahwa pada umumnya, subyek sering merasa (sedikit) tidak aman maupun cemas, terutama kalau berkenaan dengan pemenuhan kebutuhan afeksi, ditambah subyek adalah orang yang lebih percaya dengan "inner"-nya dan tidak dapat menghadapi situasi-situasi yang mempengaruhi emosinya dengan cara yg tepat. Hal ini mengarah pada munculnya ketegangan yang sangat kuat sehingga kadang-kadang kurang bisa menggunakan rasionya, kurang mampu mengontrol emosionalnya, dan lebih memilih untuk diam tetapi sering terlihat sangat tegang dan kurang responsif. Kalaupun ada respon cenderung sifatnya dangkal, bahkan bisa ada gangguan didalam merespon lingkungannya.

c. Di bidang Sosial

Tes Rorschach di bidang sosial lebih sering digunakan sebagai sarana penelitian sosial, yang diawali oleh kelompok psychoanalytically-oriented 
Rorschachers, yang menganggap psychoanalytic hypotheses layak diper-timbangkan untuk mendapatkan interpretasi yang tepat (dengan menggunakan alat tes proyektif).

Klopfer, dkk. (1956) mengangkat beberapa penelitian yang menggunakan tes Rorschach antara lain : penelitian tentang prejudice (prasangka) oleh Frenkel-Brunswik \& Sanford : penelitian tentang perbedaan etnis dan karakter warga negara oleh Benedict, DuBois, dkk. ; penelitian tentang efek situasi sosial oleh Kimble ; penelitian tentang pilihan pekerjaan, kesuksesan, penyesuaian diri dan kepribadian oleh Anne Roe, dsb.

\section{d. Di bidang Industri}

Teknik Rorschach juga banyak digunakan di luar bidang klinis, seperti di bidang industry. Penggunaan tes Rorschach di bidang industri sudah sering dilakukan, seperti halnya tes proyektif lain seperti TAT, Szondi, Drawing Completion Test, baik di area pekerjaan.

Di bidang ini, Tes Rorschach digunakan sebagai salah satu battery test, dan digunakan bila berurusan 
dengan variabel kepribadian di area pekerjaan, bahkan sudah dipakai sejak perang dunia II. Di sini tes Rorschach banyak digunakan sebagai alat seleksi, atau penggunaan secara kelompok (William \& Kellman dalam Klopfer, 1954), maupun penelitian.

Penjelasan di atas membuktikan tes Rorschach bisa digunakan di banyak bidang seperti bidang klinis, pendidikan, sosial, maupun indistri, dan dapat digunakan untuk mengenali jenis gangguan psikologis, organisasi kepribadian dan perbedaan individual, maupun untuk penelitian.

\section{Kesimpulan}

Tes Rorschach merupakan salah satu tes psikologi proyektif non verbal yang digunakan untuk mengetahui gambaran kepribadian seseorang

Teknik proyektif non verbal, yaitu tes proyektif yang hanya instruksinya saja yang memakai bahasa, tetapi stimulusnya bisa berupa gambar cerita, bercak tinta, atau goresan tangan. Pada Tes Rorschach, stimulusnya berupa bercak tinta.

Kesimpulan yang didapat dari suatu tes kepribadian, termasuk Tes Rorschach, hanya merupakan predisposisi kepribadian 
dari orang yang deberi tes, sehingga perubahan bisa menghasilkan hal-hal yang berbeda. Dalam hal ini, psikotes tidak bisa disalahkan karena dari tes hanya bisa didapat potensinya saja.

Tes Rorschach merupakan salah satu tes psikologi yang digunakan untuk mengetahui gambaran kepribadian seseorang, usaha untuk penanganan kasus, juga untuk pengembangan ilmu lewat penelitian. Aplikasi Tes Rorschach menjangkau di berbagai area, seperti area klinis (area awal menggunaan tes Rorschach), industri, dan berkembang di area pendidikan, dan sosial.

\section{Latihan soal :}

1. Jelaskan apa yang dimaksud dengan Tes Rorschach sebagai tes psikologi proyektif non verbal!

2. Jelaskan maksud dari pernyataan "Untuk mengungkap kepribadian seseorang, Tes Rorschach memanfaatkan appersepsi seseorang."

3. Jelaskan apa kelebihan penggunaan tes Rorschach, sehingga kita bisa memutuskan apakah akan menggunakan tes Rorschach atau tidak dalam usaha untuk mengetahui kepribadian seseorang ! 
4. Tes Rorschach digunakan di banyak bidang, seperti klinis, industri, pendidikan, mapin sosial. Cari jurnal penelitian penggunaan Tes Rorschach di masing-masing bidang !

\section{Referensi :}

Abt, L, E \& Leopold Bellak : "Proyective Psychology. Clinical Approach to The Total Personality”. 1959. Grove Press Inc, London.

Anastasi, A. \& Urbina, S., 1997. Psychological Testing. Seventh Edition. Alih Bahasa : Drs. Robertus Hariono S.I, MA. 2007. Tes Psikologi. PT Indeks, Jakarta.

Klopfer, B, dkk, 1956. Development in The Rorschach Technique. Development in The Technique and Theory. Volume I. Harcourt, Brace, \& World, Inc., New York, USA.

Marnat, G.G., 2009. Handbook of Psychological Assessment. Fifth Edition. Alih bahasa : Drs. Helly P.P, MA. \& Dra. Sri Mulyantini S., 2010. Cetakan I. Pustaka Pelajar, Yogyakarta.

Retno, E.,D \& Sarlito Wirawan Sarwono, 2008. Profil Kepribadian Pria Pedofilia Melalui Tes Rorschach. JPS Jurnal Psikologi Sosial. Fakultas Psikologi Universitas Indonesia, Jakarta. 


\section{BAB II \\ KONSEP, TEORI, DAN ASPEK KEPRIBADIAN \\ TES RORSCHACH}

\section{Kemampuan Akhir Yang Direncanakan}

Setelah mempelajari bab ini,

diharapkan mahasiswa mampu

memahami konsep proyeksi dari Tes

Rorschach, teori-teori yang

melatarbelakangi tes Rorschach, dan

aspek kepribadian Tes Rorschach.

Seperti hal nya tes psikologi yang mengungkap kepribadian, maka tes Rorschach juga memiliki latar belakang teori kepribadian yang dikenal di bidang psikologi. Konsep teori kepribadian ini biasanya digunakan saat seorang psikolog menginterpretasi perilaku proyektif yang dihasilkan dari pelaksanaan asesmen psikologi.

Secara umum konsep kepribadian yang digunakan dalam tes Rorschach berdasar pada salah satu postulat kepribadian yang dikenal di psikologi proyektif, yang menyatakan bahwa kepribadian merupakan suatu sistem yang berfungsi pada diri 
individu sebagai suatu organisasi antara stimulus dan respon. Postulat ini menekankan pada kondisi dan sifat stimulus, dan menyatakan bahwa setiap stimulus mampu membangkitkan respon individu, dan ini terjadi melalui proses belajar individu. Stimulus yang dipelajari individu untuk direspon tergantung pada : keunikan, kebutuhan, nilai-nilai individual yang ada pada seseorang (Abt \& Bellak, 1595). Penjelasan konsep dan teori yang melandasi tes Rorschach akan di bahas di sini.

\section{II.1 KONSEP DASAR TENTANG TES RORSCHACH}

Tes Rorschach dikembangkan oleh Hermann Rorschach, dan diterbitkan pertama kali pada tahun 1921. Tes Rorschach dikenal sebagi tes bercak tinta, karena tes ini menggunakan bercak tinta sebagai stimulusnya, yang bisa digunakan sebagai alat bantu diagnosis kepribadian secara menyeluruh yang meliputi aspek-aspek kepribadiannya, seperti : aspek intelektual, aspek emosional, dan sebagainya, yang akan dijelaskan lebih rinci pada bagian lain.

Pembuatan tes ini sendiri mengalami proses yang panjang, bahkan sesudah terbentuknya tes rorschach , masih ada perubahan-perubahan pada tes Rorschach asli 
yang dilakukan pengikut Rorschach untuk tujuan tertentu. Sebagian besar penelitian menggunakan bercak ini sebagai metode untuk mempelajari "imajinasi visual" melalui analisis terhadap konten/isi responrespon yang diberikan subyek. Sedangkan Rorschach mampu lebih dari itu, bahwa gambaran aspek formal dan struktural dari reaksi-reaksi subyek terhadap bentuk-bentuk dapat mewakili bagaimana "kepribadian dasar subyek".

Imajinasi visual yang dilakukan oleh testee bukan sekedar imajinasi seseorang terhadap stimulus visual, tetapi imajinasi visual yang hasilnya bisa mengungkap aspek-aspek kepribadian individu. Hal ini bisa terjadi setelah, pada tes Rorschach, testee diminta untuk menyebutkan gambar apa yang berhasil dilihat dari kartu Rorschach yang berupa gambar bercak tinta. Gambar-gambar pada kartu Rorschach terbuat dari percikan tinta yang kemudian dilipat sehingga menghasilkan gambar-gambar yang simetris (sama sisi kiri dan kanan). Gambar-gambar tersebut akan diberikan kepada testee, dan testee diminta untuk menyebutkan apa saja yang bisa dilihat dari gambar kartu Rorschach sesegera mungkin atau secara 
spontan. Imajinasi visual ini berlangsung karena gambar bercak tinta yang ada pada kartu Rorschach berbentuk abstrak, ambigius, dan tidak terstruktur. Terhadap gambar yang seperti ini, testee akan menyebutkan jawabannya berdasar pada apa yang pernah ada dalam ingatannya. Asumsi ini dinyatakan oleh Freud (dalam Abt \& Bellak, 1959) bahwa ingatan tentang sesuatu yang pernah ditangkap indera (=sensasi) akan mempengaruhi persepsi terhadap stimulus-stimulus yang sejenis. Seorang testee bisa "mengimajinasikan" gambar kelelawar pada kartu I Rorschach karena saat melihat keseluruhan bercak tinta membuat testee "teringat" dan memaknai (mempersepsi) bercak tinta itu berbentuk "seperti" keleawar, sehingga testee menyebutkan kelelawar sebagi jawabannya.

Menurut Rorschach, persepsi muncul dari adanya sensasi atau sekelompok sensasi (= yaitu proses dimana manusia menerima informasi sensoris melalui penginderaan dan menerjemahkan informasi tersebut menjadi sinyal-sinyal "neural" yang bermakna), yang kemudian memancing memori berupa gambar-gambar dari sekelompok sensasi yang lebih dahulu kita miliki. 
Apabila diperhatikan, terdapat 3 (tiga) proses yang berlangsung yaitu sensasi, memori, dan asosiasi.

Dalam proses persepsi, seperti yang terjadi pada tes Rorschach, individu akan menstruktur dirinya kepada orang lain (yaitu : tester), sehingga diharapkan apa-apa yang ada dalam diri individu akan diproyeksikan begitu melihat gambar Rorschach yang diberikan oleh tester, dan setiap individu akan memberi arti pada stimulus dengan cara yang berbeda meskipun obyek sensasinya sama. Ada orang yang akan / bisa mengerjakan sesuatu dalam situasi yang bebas / tanpa kontrol (seperti pada situasi tes Ro), tetapi yang lainnya malah sebaliknya. Hal ini bisa terjadi apabila individu dihadapkan pada stimulus yang kabur / tidak menentu / ambigius dan tidak terstruktur. Apabila seseorang menangkap suatu stimulus yang ambigius, maka yang terjadi adalah proses pemberian makna pada stimulus tersebut sesuai dengan dorongan, perasaan, atau sentimen seseorang (Dalam psikologi proyektif, istilah yang lebih tepat untuk pemberian makna ini adalah proses appersepsi, bukan persepsi). Oleh karena itu reaksi/respon itulah yang dianggap sebagai manifestasi / proyeksi dari berbagai aspek kepribadian individu. 
Secara teori, saat seseorang menghadapi suatu stimulus yang ambigius, maka hal-hal yang kita proyeksikan ke dunia luar dapat menjelma menjadi sesuatu yang lain tetapi ingatan tentang bentuk suatu benda muncul sesuai dengan apa yang ditangkap indera, dan di kesadaran (Freud, dalam Abt \& Bellak, 1959).

\section{II.2. TEORI KEPRIBADIAN YANG MENDASARI TES RORSCHACH}

Asumsi dasar yang mendasari teknik rorschach adalah adanya relationship antara persepsi dengan kepribadian. Secara skematis bisa dijelaskan seperti tampak pada gambar di bawah :

\section{gambar 1 : \\ skema proses persepsi}

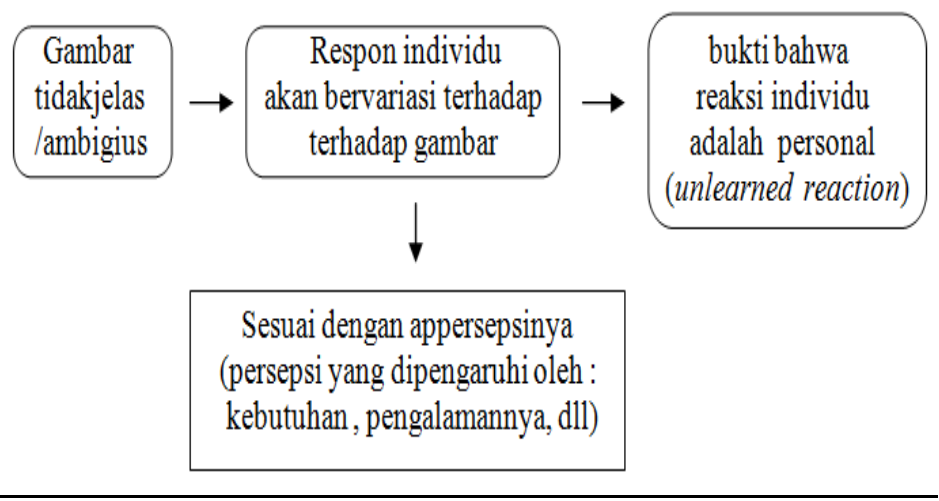


Jadi, gambar yang dipersepsikan subyek pada dasarnya mem-proyeksikan aspek-aspek kepribadiannya, yaitu antara lain mengungkap :

- Sifat dasar dorongan-dorongan individu,

- Motivasi dan dorongan individu,

- Cara individu mengatasi masalahnya, dan sebagainya.

Dengan kata lain, hasil persepsi individu terhadap gambar pada kartu-kartu Rorschach mengungkap private world ( disini individu tanpa sadar sebenarnya menceritakan pribadinya ) misal :

c) dalam kehidupan sehari-hari , individu cenderung menolak untuk mengadakan relasi dengan orang disekitarnya, karena mereka tidak menyenangkan dan menyebabkan individu tersebut merasa tidak tenang atau gelisah.

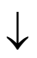

maka pada kartu Rorschach, bisa tampak pada respon-respon dimana individu menolak melihat orang/manusia, individu benar-benar tidak melihat/menangkap figur manusia pada gambargambar di kartu Rorschach. Individu cenderung 
malah melihat hal lainnya, seperti hewan, tumbuhtumbuhan, gunung-gunung dengan awannya, dsb.

d) dalam kehidupan sehari-hari, individu tidak mau menghadapi sumber permasalahan, melainkan hanya nyrempet saja.

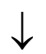

maka pada kartu Rorschach, individu cenderung hanya menaruh perhatian pada daerah-daerah pinggir dari gambar-gambar di kartu Rorschcah (terwakili oleh adanya skor unusual detail "de"). Hanya memperhatikan bagian-bagian kecil sekali pada gambar-gambar di kartu Rorschach (terwakili oleh adanya skor unusual detail "dd").

Bagaimana kita memperoleh / mengetahui adanya aspek-aspek kepribadian seperti tersebut di atas ? Antara lain bisa diketahui dari :

1. Bagian-bagian dari bercak tinta yang dipilih individu.

2. Apa yang individu lihat atau tidak dilihat.

3. Bagaimana individu mengorganisir materi gambar. 
4. Berapa lama individu melihat (untuk menentukan apa yang individu lihat), dsb.

Beberapa hal di atas mengungkap karakter kepribadian individu. Hal tersebut baru bisa muncul, kemungkinan besar pada saat pemberian tes Rorschach, karena pada situasi sebenarnya individu sebagai "individu normal" terbiasa (telah belajar) untuk mengontrol diri agar tampak baik dan menyenangkan. Dengan kata lain, individu telah belajar berperilaku yang bisa diterima masyarakat, sehingga sikap perasaan yang sebenarnya tidak tampak. Individu seperti ini bila dihadapkan pada situasi tes Rorschach, ia tidak akan bisa mengontrol diri untuk bersikap dengan cara yang benar, yaitu cara yang dianggap paling baik dilakukan, dan tanpa bisa dikontrol individu memberi respon sesuai dengan cara atau konsep seperti dirinya sendiri apa adanya. Dengan kata lain, dalam merespon gambar di kartu Rorschach, secara tidak sadar sebenarnya individu mengungkap keadaan (sikap dan perasaan)nya, bahkan bagian dari dirinya tanpa disadarinya sama sekali. Reaksi/respon yang diberikan individu ini dianggap sebagai manifestasi/proyeksi dari berbagai aspek kepribadian individu. 
Dari hal di atas dapat disimpulkan bahwa: Tes Rorschach merupakan tes kepribadian (karena tujuannya adalah mengetahui/mendeskripsikan aspekaspek kepribadian seseorang) dengan menggunakan teknik proyeksi, sehingga disebut juga tes proyeksi, karena memproyeksikan hal-hal yang ada dalam diri individu.

Tes Rorschach berhubungan dengan persepsi, terutama berhubungan dengan visual. Dasar proses persepsinya adalah komponen gestalt. Oleh sebab itu hasil tes Rorschach adalah hasil komponen gestalt, misal : bila seseorang memiliki berbagai trait/sifat kepribadian, maka dengan bantuan tes Rorschach akan diperoleh komponen-komponen tertentu yang saling berhubungan satu dengan lain. Jadi, harus dilihat secara gestalt, caranya dengan melalui gambaran dinamika kepribadiannya, tidak dilihat sebagai unsur-unsur kepribadian yang berdiri sendiri (Abt \& Bellak,1959).

\section{II.3. ASPEK KEPRIBADIAN YANG TERGALI DARI TES RORSCHACH}

Aspek-aspek kepribadian apa saja yang bisa digali dari Rorschach meliputi 3 bagian besar : 
A. Aspek intelektual / cognitive

Aspek Intelektual / cognitive , antara lain mencakup :

1. Status dan fungsinya intelegensi :

- Bagaimana taraf intelektual individu.

- Apakah dioperasikan/direalisasi sesuai sesuai dengan potensinya (seperti pada tes intelegensi)

- Apakah ada tekanan emosi, sehingga mempengaruhi berfungsi-nya (taraf) intelektualnya.

- Dilihat juga efektivitas dan produktivitasnya.

2. Manner of approach

- Bagaimana pendekatan individu terhadap masalah ? Logis atau kacau ? Metodis atau sembarangan? Induktif atau deduktif?

- Bagaimana cara mengorganisir masalah ? Apakah langsung me-nyelesaikan sumber masalah, atau hanya nyrempet-nyrempet saja ? Apakah secara tertib, praktis ? dsb.

3. Kemampuan mengobservasi

- Apakah mampu mengobservasi sesuatu yang nyata ? Bisa melihat hal-hal seperti yang biasa 
dilihat oleh orang lain ? Apakah bisa melihat hal - hal yang lebih kompleks ?, dsb.

4. Keaslian didalam berpikir

- Apakah individu memiliki cara berpikir yang original? Apakah kreatif ? Apakah kreasikreasi yang muncul berdasar realitas atau fantasi ? dsb.

5. Produktivitas

- Apakah individu tersebut produktif ? Bagaimana kualitas respon yang berhasil diproduksi ? Apakah respon-responnya kaya atau miskin? dangkal, dsb.

6. Variasi interest / minat

- Apakah bervariasi minatnya ? Apakah luas atau terbatas ? Apakah terpaku pada suatu masalah ? Apakah ada minat khusus ?, dsb.

B. Aspek affektif / emotional

Aspek Afektif / Emotional, meliputi :

1. Sifat emosi secara umum

- Apakah spontan, depresif, menarik diri, pencemas, pasif, tegas, agresif, menonjolkan diri ? 
- Bagaimana cara individu memberikan respon bila menghadapi situasi yang memancing emosi ?

- Apakah pesimis didalam memperoleh kasih sayang yang di-harapkan ? Apakah realistis atau tidak ? Berdiri sendiri atau tergantung ?, dan sebagainya.

2. Feeling terhadap dirinya

- Bagaimana respon terhadap dorongannya ?

- Apakah menerima keadaan dirinya ?

- Apakah mengolah dorongan yang muncul ?

- Adakah perasaan tidak cocok dengan dirinya ?, dan sebagainya.

3.Responsiveness terhadap orang-orang

- Bagaimana membina hubungan dengan orang lain. Apakah senang membina hubungan ? Apakah bisa sesuai dengan orang lain ?

- Apakah takut terhadap orang lain ? Apakah selalu menghindari kontak dengan manusia atau justru lebih akrab dengan hal-hal dunia ? 
4. Reaksi terhadap stres emosional

- Bagaimana responnya dalam situasi-situasi yang menekan / stress full. Mampu ataukah gagal menghadapinya ? Apakah panik ?

- Bagaimana reaksi terhadap situasi baru, apakah mampu menguasai situasi atau malah gagal ?

5. Kontrol terhadap impuls-impuls emosional

- Bagaimana individu mengontrol impulsimpuls yang muncul se-cara spontan. Adekuat

? kaku? atau impulsif?

C. Aspek fungsi-fungsi ego / ego-fuctioning

Aspek Berfungsinya Ego, meliputi :

1. Ego strength

- Apakah individu cenderung "reality-testing"? apakah cara mem- persepsikannya wajar/jelas ?

- Bagaimana penilaian terhadap dirinya sendiri ? Apakah menon-jolkan diri atau sebaliknya ? Apakah individu membutuhkan semacam konseling atau psikoterapi ? 
2. Area konflik

- Apakah secara seksual merasa sesuai ? Apakah ada kekaburan terhadap sex-role dan identifikasinya ? Apakah ada konflik tentang sikap individu terhadap otoritas ? atau terhadap kebutuhan-kebutuhan untuk dependency, pasif ?, dsb.

3. Defenses

- Defens apa yang digunakan individu ? represi ? denial ? inte-lektualisasi ? Banyakkah defens yang digunakan atau hanya itu-itu saja ? Bervariasikah ? fleksibel-kah ?

Harus diingat, Tes Rorschach merupakan tes yang tidak terstruktur dan ambigius, sehingga jawaban tergantung pada persepsi / proyeksi seseorang, Jawaban yang diberikan seseorang tergantung pada pengalaman, kebiasaan hidup, halhal yang melatar belakangi ( misal : budaya, pendidikan, dsb.). Oleh karena itu, jawaban-jawaban yang diberikan seseorang dari tes Rorschach dianggap benar dan semua harus dievaluasi. Jawaban seseorang pada tes Rorschach merupakan jawaban yang khas dari orang yang bersangkutan. 


\section{Kesimpulan}

Asumsi dasar yang mendasari tes rorschach adalah adanya relationship antara persepsi dengan kepribadian.

Hasil persepsi individu terhadap gambar pada kartu-kartu Rorschach mengungkap private world

Tes Rorschach dikenal sebagi tes bercak tinta, karena tes ini menggunakan bercak tinta sebagai stimulusnya, yang termasuk dalam jenis stimulus yang ambigius.

Seseorang yang menangkap suatu stimulus yang ambigius, akan memberi makna pada stimulus tersebut sesuai dengan dorongan, perasaan, atau sentimen seseorang, sehingga respon individu dianggap sebagai manifestasi / proyeksi dari berbagai aspek kepribadian individu.

Aspek kepribadian yang bisa diperoleh dari tes Rorschach mencakup 3 aspek yaitu : (1) Aspek Intelektual / cognitive, (2) Aspek affektif / emotional, dan (3) Aspek fungsi-fungsi ego / ego-fuctioning. 


\section{Latihan soal :}

1. Jelaskan bagaimana gambar bercak tinta pada kartu Rorschach bisa mengungkap kepribadian seseorang !

2. Hasil persepsi individu terhadap gambar pada kartu-kartu Rorschach mengungkap private world. Apa yang dimaksud dengan private world?

3. Jawaban-jawaban yang diberikan seseorang dari tes Rorschach dianggap benar dan semua harus dievaluasi. Penjelasan apa yang saudara bisa berikan untuk penyataan tersebut?

4. Aspek kepribadian apa saja yang bisa digali dari tes Rorschach ? 


\section{Referensi :}

Abt, L, E \& Leopold Bellak : "Proyective Psychology. Clinical Approach to The Total Personality”. 1959. Grove Press Inc, London.

Anastasi, A. \& Urbina, S., 1997. Psychological Testing. Seventh Edition. Alih Bahasa : Drs. Robertus Hariono S.I, MA. 2007. Tes Psikologi. PT Indeks, Jakarta.

Klopfer, B, dkk, 1956. Development in The Rorschach Technique. Development in The Technique and Theory. Volume I. Harcourt, Brace, \& World, Inc., New York, USA.

Nastiti, D., 2005. "Handout Psikologi Proyektif. Pengantar Pemahaman Dasar Tes Kepribadian dan Pengenalan Tes-tes Kepribadian". Surabaya 


\section{BAB III \\ PENGENALAN ALAT TES}

\section{Kemampuan Akhir Yang Direncanakan}

Setelah mempelajari bab ini, diharapkan mahasiswa mampu sejarah perkembangan

Tes Rorschach, mengetahui validitas dan reliabilitas Tes Rorschach, serta memahami dan mengenali alat Tes Rorschach, dan karakteristik kartu Tes Rorschhach

Tes Rorschach merupakan cara / prosedur untuk mengungkapkan kepriba-dian individu dengan menggunakan teknik proyektif yang menggunakan bercak tinta sebagai stimulusnya. Diantara jajaran tes jenis ini tes Rorschach menempati jenjang pertama, artinya merupakan tes dengan teknik proyektif, baik sebelum Rorschach melaporkan hasil pe-nelitiannya maupun sesudahnya. 
Pada tahun 1960-an, Tes Rorschach merupakan tes psikologi yang paling umum digunakan. Di Amerika Serikat, Tes Rorschach adalah tes ke- 8 yang paling sering digunakan pada pasien gangguan mental pada saat itu. Tes ini juga menjadi tes yang paling sering digunakan oleh Society for Personality Assessment, untuk asesmen kasus penilaian forensik (25\%) (bersama MMPI-2). Menurut survey, pengguna Tes Rorschach sebagian besar adalah psikolog koreksional (20\%), dan psikolog klinis (80\%).

Beberapa ahli menyarankan untuk menggunakan Tes Rorschach bersama TAT untuk mengungkap kepribadian secara lengkap, karena TAT dianggap yang paling populer setelah Tes Rorschach. Beberapa psikolog menggunakan tes ini untuk mengetahui karakter dan emosional seseorang. Selain itu, Tes Rorschach juga telah sering digunakan untuk mendeteksi masalah-masalah gangguan psikologis, seperti : gangguan pikiran, terutama dalam kasus dimana pasien enggan menyampaikan proses berpikir mereka secara terbuka.

Tes Rorschach dikembangkan oleh HERMANN RORSCHACH, dan diterbitkan pertama kali pada tahun 1921. Tes Rorschach ini menggunakan bercak tinta sebagai alat bantu didalam usaha menegakan diagnosis kepribadian 
secara menyeluruh yang meliputi aspek-aspek kepribadiannya, seperti : aspek intelektual, aspek emosi-onal, dan sebagainya, yang akan dijelaskan lebih rinci pada bagian lain.

\section{III.1 Sejarah Perkembangan Tes Rorschach}

Pembuatan tes ini sendiri mengalami proses yang panjang, bahkan sesudah terbentuknya tes rorschach, masih ada perubahan-perubahan pada tes Rorschach asli yang dilakukan pengikut Rorschach untuk tujuan tertentu. Sejarah perkembangan tes Rorschach ini meliputi masa sebelum terbentuknya tes Rorschach, saat terbentuknya tes Rorschach, dan sesudah terbentuknya tes Rorschach.

\section{A. Masa sebelum terbentuknya Tes Rorschach}

Banyak psikolog sebelum Rorschach telah menggunakan bercak tinta, tetapi tes Rorschach merupakan titik kulminasi lebih dari 20 tahun eksperimen dengan bercak tinta yang telah dilakukan di Eropa dan Amerika.

Sebagian besar penelitian menggunakan bercak ini sebagai metode untuk mempelajari "imajinasi visual" melalui analisis terhadap konten/isi respon- 
respon yang diberikan subyek. Sedangkan

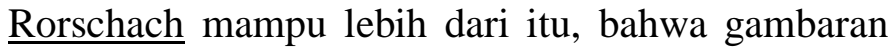
aspek formal dan struktural dari reaksi-reaksi subyek terhadap bentuk-bentuk dapat mewakili bagaimana "kepribadian dasar subyek".

Gambaran perkembangan pembuatan tes Rorschach secara detil sebagai berikut :

1. Justinus Kerner (1857), di laboratorium Tubingen Jerman, secara tidak sengaja mulai menyadari melihat banyak obyek pada bercakbercak tinta. Hanya saja Kerner tidak segera menangkap adanya kemungkinan hubungan antara persepsi terhadap bercak tinta dengan diagnosis tentang kepribadian. Kerner lebih tertarik memperhatikan pengaruh bercak tinta terhadap respon yang diberikan subjek.

2. Alfred Binet (1895), yang terkenal dengan tes inteligensi, meng-anggap bahwa bercak tinta dapat digunakan dalam penelitian tentang inajinasi visual untuk studi sifat-sifat kepribadian.

3. Dearborn (1896), Universitas Harvard, mempublikasikan artikel-nya tentang : (a) 
bagaimana membuat bercak tinta, baik yang hitam - putih maupun berwarna, (b) cara menggunakan bercak tersebut dalam psikologi eksperimen.

Selain itu dia juga melaporkan hasil eksperimennya terhadap mahasiswamahasisiswa dan profesor-profesor di Harvard dengan 12 set bercak yang masing-masing set terdiri dari 10 bercak tinta.

Hasil observasinya membayangi logika Rorschach dari tulisannya :

"Mengapa seseorang melihat di bercak seperti suatu "gum-palan kubis", dan kemudian "binatang dengan mulut terbuka", atau mengapa seorang profesor melihat bercak sebagai "kumpulan bunga kacang polong" dan istrinya melihat "ular membelit kayu". Jelas bahwa, pada prinsipnya, pengalaman, khususnya pengalaman awal subyek, sangat mempengaruhi, dst... “"

4. Kirkpatrick (1990), memberikan bercak tinta pada anak-anak dan menggabungkan dengan tes lain. Ia menganggap bahwa faktor yang mempengaruhi kualitas respon seseorang terhadap suatu stimulus adalah usia. 
5. Pyle (beberapa tahun kemudian), menyatakan kalau bercak tinta bisa digunakan untuk menguji kecepatan proses asosiasi.

6. Whipple (1910), mempublikasikan satu sumbangan penting ter-hadap perkembangan tes Rorschach ini, yaitu : (a) seri bercak tintanya merupakan seri I yang terstandardisasi, (b) manualnya merupakan yang pertama kali dipakai oleh para eksperimenter bercak tinta. Manualnya sangat bebeda dengan periode Rorshach dan sesudahnya, dan perhatiannya masih kecil terhadap kemungkinan adanya hubungan antara karakteristik kepribadian subyek dengan respon-respon nyata mereka. Bercak-bercaknya masih menggambarkan secara luas tentang proses-proses imajinatif.

7. F.C. Bartlett (1916), Universitas Cambridge, menggunakan bercak sebagai bagian dari uji perlengkapan dalam suatu studi tentang persepsi dan imajinasi.

Dengan menggunakan 36 subyek penelitian, didapatkan hasil yang menyatakan bahwa bercak-bercak tersebut dianggap mampu 
menunjukkan minat dan mungkin pekerjaan subyek.

8. Cicely Parson (1917), Universitas College of South Wales, me-lakukan penelitian terhadap 97 anak muda (murid-murid Sekolah Dasar dan Menengah) dengan menggunakan bercak standart Whipple. Parson menemukan adanya : (a) respon-respon hewan dan manusia (persentase tinggi); (b) perbedaan hasil berdasar jenis kelamin; (c) gradasi tipe dan kualitas deskripsi tergantung pada usia.

Hasil tersebut menunjukkan adanya kemungkinan-kemungkinan yang bisa menjelaskan adanya perbedaan individual yang signifikan, meskipun tujuan penelitiannya mengukur imajinasi.

Dari seluruh penemuan di atas, ternyata analisis konten yang dilakukan oleh Bartlett maupun Parson terhadap respon subyek memberi sumbangan yaitu mengarahkan bentuk formula Rorschach. Analisis yang mereka lakukan mengingatkan Rorschach untuk meluaskan dasar interpretasinya. 


\section{B. Masa terbentuknya Tes Rorschach}

Pada masa pembuatan tes bercak tinta ini, Rorschach memulainya dengan membuat ribuan kartu dengan bercak tinta. Dari ribuan kartu bercak tinta ini Rorschach memilih 40 kartu bercak yang selanjutnya dicobakan pada subyek sebanyak 1911 orang. Kartu bercak yang sudah terpilih tersebut masih disaring lagi hingga diperoleh 15 kartu bercak yang dianggap memuaskan. Pada saat diterbitkan, ia terpaksa harus memilih 10 kartu saja karena biaya pencetakan dianggap mahal, terutama pada kartu bercak yang berwarna. Sepuluh kartu yang terpilih paling akhir inilah yang paling sering digunakan, dan yang dikenal dengan Tes Rorschach.

Tes Rorschach dipublikasikan pertama kali oleh Rorschach pada tahun 1921 dalam tulisannya yang berjudul "Psychodiagnostik", yang berisi tetang metode dan hasil dari eksperimen diagnostiknya yang didasarkan pada persepsi, dan mencakup juga interpretasi dengan accidental form (bentuk interpretasinya dibuat begitu saja / belum baku). 
Awal perkembangan Tes Rorschach, dimulai dari banyaknya psikolog sebelum Rorschach yang menggunakan bercak tinta, tetapi tes Rorschach merupakan titik kulminasi lebih dari 20 tahun eksperimen dengan bercak tinta yang telah dilakukan di Eropa dan Amerika (Klopfer,1962). Di Amerika saja dikenal ada beberapa cara administrasi dan prosedur interpretasi, tetapi sistem yang paling populer adalah sistem yang dikembangkan oleh Klopfer dan Beck. Mereka secara intensif mengembangkan Tes Rorschach ini.

Pada bulan-bulan terakhir hidupnya, dengan sangat antusias Rorschach mencurahkan perhatiannya karena tekniknya dinilai sangat menjanjikan, karena disamping terbukti berguna sebagai alat diagnostik (alat untuk membedakan pasien klinis dan normal), tekniknya juga dapat digunakan untuk mengungkap dan mendeteksi kualitas-kualitas tertentu pada subyeknya, seperti : sifat kepribadian, kebiasaan, dan gaya berpikir dalam memecahkan masalah. Dengan kata lain, disamping berguna untuk keperluan klinis, teknik ini 
juga dapat digunakan untuk mengenali organisasi kepribadian dan perbedaan individual.

\section{Masa sesudah terbentuknya Tes Rorschach}

Setelah meninggal tahun 1922, pengembangan tes dilakukan oleh rekan-rekan dan mahasiswanya. Dalam dasawarsa berikutnya, penggunaan teknik Rorschach amat luas, baik di Eropa maupun di Amerika Serikat. Dengan meninggalnya Rorschach berakibat pada tidak adanya penyusun sistematika tunggal. Hal ini menyebabkan prosedur pelaksanaan, skoring maupun interpretasinya menjadi berkembang biak kedalam berbagai metode atau sistem. Hal ini berlangsung mulai tahun 1930an sampai tahun 1960-an, dimana terdapat perbedaan pada metode skoring dan soal-soal interpretifnya, yang terjadi karena ketidakjelasan dasar yang dipakai untuk interpretasi hasil tes-nya, apakah berdasar pada isi responnya, atau karakteristik formalnya (seperti : lokasi, determinan, kualitas bentuk, dsb yang diturunkan dari responnya). 
Tes Rorschach sudah mengalami banyak penyempurnaan yang di lakukan oleh para ahli, antara lain :

1. Pada tahun 1924, Rorschach bersama asistennya, Emil Obelholzer membuat tulisan yang menjelaskan tentang analisis yang dilakukan dalam teknik Rorschach dan juga didemonstrasikan cara penyekoran serta interpretasinya.

2. David Levy, mencoba memperkenalkan tes Rorschach di Amerika.

3. Samuel Beck, menerbitkan bercak tinta yang digunakan untuk tes Rorschach, serta mengembangkan metode untuk melakukan interprestasi. Sampai sekarang metode ini masih dipakai.

4. Hertz, adalah tokoh yang banyak mengadakan penelitian tentang aspek-aspek metodologis dalam menggunakan tes Rorschach.

5. Bruno Klopfer, mencoba mengembangkan tes Rorschach.

Pada tahun 1934 telah mengembangkan ide-ide Rorschach dalam kelompok studinya. Pada tahun 
1936 Klopfer dkk mendiri-kan Rorschach Institute sebagai lembaga yang melatih para ahli didalam menggunakan tes Rorschach. Pada tahun 1948 Rorschach Institute ini telah berubah menjadi The Society for Projective Technique, yang menerbitkan TAT (Thematic Apperception Test) dan tes-tes proyektif lainnya.

6. Holtzman, berusaha memperbaiki kelemahankelemahan metodo-logi didalam penggunaan tes Rorschach dengan membuat Holtzman Ink Blot Technique

Dampak yang muncul selanjutnya adalah :

7. Pada tahun 1960-an tes Rorschach menjadi kurang dihargai sebagai instrumen psikometris. Terbukti, banyak psikolog klinis yang terus menggunakan tes Rorschach secara reguler, tetapi sebagian besar mengaku bahwa mereka cenderung menggunakan data tes Rorschach dengan cara mereka sendiri (misal : melakukan inter-pretasi yang sama sekali impresionistik dan kualitatif, atau mengikuti 1 (satu) sistem atau 
lebih, yang menurut mereka lebih ketat dan mereka merasa cocok)

8. Pada tahun 1969, John E. Exner bekerjasama dengan Samuel Beck dan Bruno Klopfer melakukan penelitian yang berusaha me-rangkum semua segi penggunaan klinik tes Rorschach dan penelitian kepustakaan.

Penelitian Exner, Beck, dan Kopfer ini, secara empiris berguna dan dapat dipertahankan ke dalam 1 (satu) sistem tunggal. Setelah seperempat abad selanjutnya, mereka berhasil menempatkan tes Rorschach atas dasar psikometris yang kuat (Anastasi \& Urbina, 2007).

\section{III.2 VALIDITAS dan RELIABILITAS TES RORSCHACH}

Tes Rorschach telah memenuhi standardisasi

karena alat tes ini telah melewati proses penelitian dan eksplorasi selama 10 tahun, yang telah dilakukan Rorschach terhadap populasi pasien di Rumah Sakit tempat Rorschach menjabat sebagai kepala psikiater. 
Meskipun sudah jelas kalau Rorschach menghasilkan informasi klinis yang berharga, validitas tes Rorschach masih sering dipertanyakan. Dalam hal ini Klopfer (1962) memberikan komentar bahwa penggunaan tes Rorschach yang sudah meluas telah menghasilkan suatu validitas klinis, yang mungkin tidak sejalan dengan validitas secara statistik. Oleh karena itu, validitas tes Rorschach agak berbeda dengan validitas dalam pengertian umum, bahkan mungkin dibutuhkan suatu bentuk validitas yang baru.

Sampai sejauh mana Rorschach memberikan gambaran kepribadian yang akurat ? Penggunaan Rorschach secara luas telah menghasilkan validitas klinis yang tidak selalu bisa dibuktikan dengan validitas statistik. Klopfer \& Davidson (1962) menjelaskan sebagai berikut :

$\rightarrow$ Tes Rorschach memiliki kemiripan tetapi tetap ada perbedaannya dengan tes-tes psikologi lainnya :

1. Sebagai tes dengan teknik proyektif, Tes Rorschach lebih ber-orientasi untuk memberi gambaran daripada mengukur potensi individu dalam bentuk pola dinamis dari fungsi-fungsi atau variabel-variabel yang saling berhubungan. 
Variabel-variabel demikian yang menimbulkan validasi.

Sedangkan tes-tes psikologi lain hasilnya berupa skor yang merupakan penjumlahan komponenkomponen, seperti : perbenda-haraan kata, pengulangan angka, dsb. Didalam mengevaluasi tingkat kecerdasan seorang subyek, misalnya, pengguna tes Rorschach tidak mengukurnya dengan cara menjumlahkan komponen tapi dengan cara konfigurasi (gestalt).

Hal ini didasarkan pada postulat yang mengatakan kepribadian adalah suatu konfigurasi (Abt \& Bellak, 1959).

2. Hasil dari sesi pelaksanaan Tes Rorschach tidak terstandarisasi (dalam pengertiannya, hasil tes yang "benar-salah" yang dianggap terstandardisir) .

Suasana permisif (meski menggunakan bahan yang standar), mem-bangkitkan berbagai respons yang luar biasa, sama seperti pada interviu non-directive atau pertanyaan openended. Teknik Rorschach memberikan cara mengkomunikasikan dan menafsirkan aspek- 
aspek tertentu dari respon-respon yang ditunjukkan subyek. Hal ini merupakan sebagian penjelasan mengapa Rorschach lebih tepat disebut sebagai suatu metode atau teknik, dibanding sebagai suatu tes.

Klopfer sendiri menyebut tes ini dengan istilah Teknik Rorschach, karena istilah tes sering dikacaukan dengan alat evaluasi kemampuan atau potensi, padahal yang diperiksa dengan teknik Rorschach adalah kepribadian, yang secara teori appersepsi kepribadian dilihat sebagai suatu konfigurasi (gestalt).

Pada dasarnya, semua alat ukur psikologi sudah dihitung validitas dan reliabilitasnya, termasuk tes Rorschach yang sudah dianggap valid (psikolog yang sudah ahli dan sudah tahu validitas dari tes ini yang menguji).

Demikian juga dengan reliabilitas tes Rorschach, sudah terbukti reliabel, karena sudah diuji berulang kali. 


\section{III.3 Kartu-Kartu Tes Rorschach}

Pada awalnya materi tes Rorschach terdiri dari beribu-ribu kartu dengan bercak-bercak tintanya. Kartu ini terbentuk dari kertas yang diberi bercak/dituangi tinta, dan kemudian dilipat sehingga setelah dibuka tampak gambar-gambar yang simetris dan ambigius. Setelah diseleksi, yang dipilih adalah yang punya bentuk simetris dan bentuknya sederhana, serta bersifat sugestif. Komposisinya setelah dipilih, ada 10 buah kartu yang bisa dipakai dengan ukuran 6.15 x 9.50 inci.

Secara garis besar, 10 (sepuluh) buah kartu tes Rorschach terdiri dari :

1) 5 buah kartu akromatik (= Achromatic Card), yaitu kartu yang hanya berwarna hitam-putih, yang terdiri dari kartu-kartu I, IV,V, VI, VII.

2) 5 buah kartu kromatik (=Chromatic Card), yaitu kartu yang berwarna-warni/berwarna cerah, yang terdiri dari kartu-kartu II, VIII, IX, X.

Masing-masing kartu mempunyai karakteristik yang berbeda-beda. Bentuk, warna, shading / bayangan, white - space, dan lain-lain, berbeda-beda antara 1 kartu dengan yang lain. 
Pengenalan kartu Rorschach dan karakteristiknya akan berguna saat melakukan interpretasi kualitatif, yaitu bila respon yang dihasilkan subyek hanya 20 atau kurang .

\section{III.4 Karakteristik Kartu-Kartu Tes Rorschach}

\section{KARTU I}

- Kartu ini keseluruhan berwarna hitam keabu-abuan dan terdapat 4 "white-space".

- Kalau orang yang bersangkutan teliti akan melihat titiktitik hitam di area yang besar.

- Area percikan keabu - abuan ini tampak terbagi dalam 3 bagian :

1 area tengah, dan

2 area sisi kiri dan

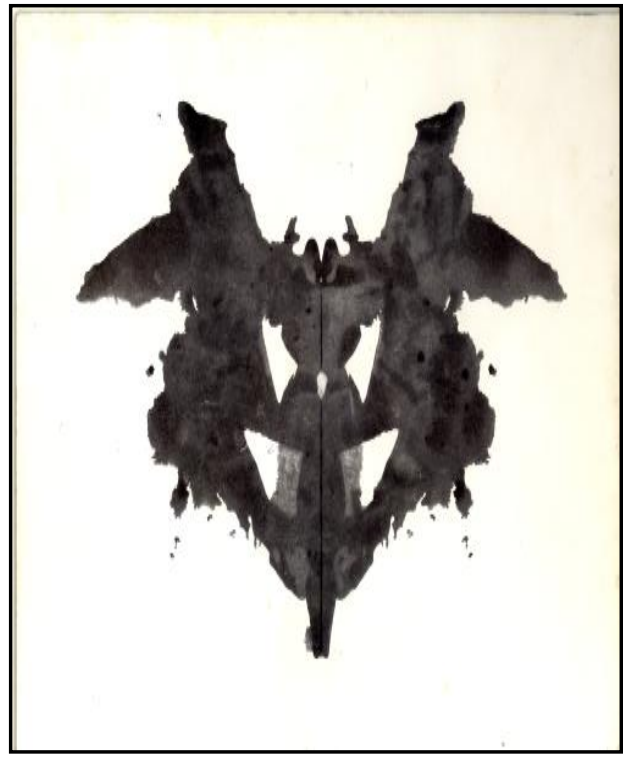
kanan.

- Reaksi-reaksi yang bisa muncul : 
1. Reaksi pertama umumnya / kebanyakan orang mereaksi bentuk ke-seluruhan gambar (wholeblot), yaitu berupa binatang bersayap misal : kelelawar, dsb.

2. Pada orang-orang yang lebih imajinatif/tidak terlalu kaku, biasanya bisa melihat sesuatu dengan banyak cara / dari berbagai sisi.

- Kadang-kadang bisa juga melihat adanya gerakan manusia pada kartu ini. Biasanya bagian tengah diproyeksikan sebagai orang dalam keadaan gerak misal : figur wanita sedang bergerak, dsb.

- Respon terhadap white-space biasanya jarang terjadi, kalaupun direspon biasanya merupakan bagian dari serangkaian tulang punggung, dsb.

- Kartu ini disebut kartu penyesuaian diri pada situasi baru, karena kecepatan dan kemampuan subyek didalam memberikan respon menunjukkan daya adaptasi.

\section{KARTU II}

- Kartu ini merupakan kartu berwarna pertama yang dijumpai. 
- Kartu ini seakan-akan terdiri dari 2 bagian : area hitam keabu-abuan yang dihubungkan oleh bercakbercak merah yang tampak jelas.

- Beberapa subyek tertentu merasa terganggu dengan adanya percikan merah ini dan pura-pura tidak melihat (terlihat dari : tidak munculnya jawaban tentang adanya warna ).

- Kartu ini terkesan terbagi menjadi 3 area yang menarik : area putih (white-space) di tengah, area kecil di atasnya, area merah di bawahnya.

- Respon yang sering muncul :

1. Kartu ini akan membuat subyek merespon area hitam dan merah secara terpisah.

2. Pada subyek yang mempunyai kemampuan dan minat organisasional, atau pada subyek yang 
mampu mencampur warna hitam dan merah dapat menggunakan seluruh area sebagai satu konsep.

3. Area merah di bawah sering diasosiasikan dengan respon-respon seksual.

4. Figur-figur manusia maupun hewan bisa terlihat pada area hitam dan seringkali figur hewan juga terlihat dalam bentuk bergerak.

5. Kartu ini disebut kartu agresi, karena merangsang munculnya respon yang mewaliki adanya potensi agresivitas.

6. Sifat kartu abu-abu memancing jawaban yang mengandung unsur tekstur.

\section{KARTU III}

- Kartu ini terdiri dari area yang hitam keabuan dan ada area merah di tengah, serta 2 area merah di atas.

- Kartu ini sendiri punya bentuk yang sangat sugestif.

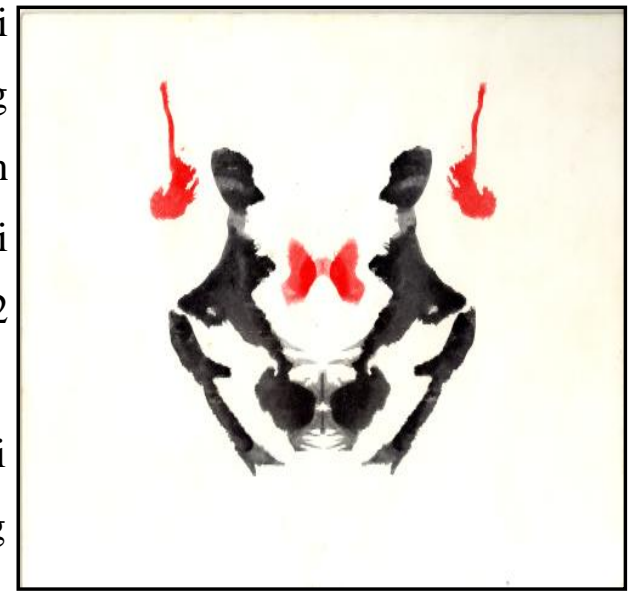

- Reaksi yang muncul : 
1. Menggunakan area hitam $\rightarrow$ biasanya melihat figur manusia bergerak.

2. Menggunakan area merah di tengah $\rightarrow$ biasanya tampak sebagai dasi kupu-kupu atau kupu-kupu.

- Reaksi yang muncul cenderung tidak keseluruhan (whole), tetapi ba-gian-bagian. Jarang sekali menggabungkan kedua area dalam satu konsep.

- Kartu ini disebut kartu manusia. Jika tidak muncul jawaban manusia, patut dicurigai kalau subyek sebenarnya mempunyai kesulitan dalam penyesuaian dengan orang lain.

\section{KARTU IV}

- Ciri kartu ini :

1. Tampak pasif, kompak / padat dan bentuk yang tidak begitu jelas.

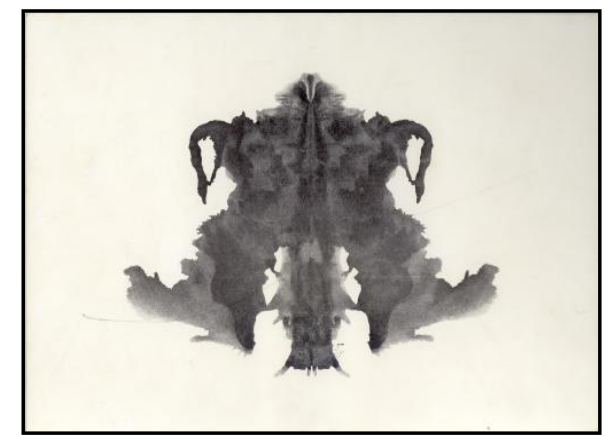

2. Terdiri dari area yang berwarna

hitam keabu-abuan dan sangat kaya

akan unsur shading di responnya. 
- Dari ciri ini, maka kartu ini sering tidak menyenangkan, sehingga memancing jawaban seperti :

1. Monster, raksasa, gorila $\rightarrow$ Mewakili hal-hal yang berkaitan dengan power/kekuatan.

2. Hutan lebat dengan gunung-gunung dan danaudanaunya.

- Kartu ini disebut sebagai kartu ayah, karena : dapat menggali sikap individu terhadap "otoritas", yang tampak dari unsur shading di jawabannya, yang menggambarkan agresivitas maskulin dan kebutuhan untuk bergantung $\rightarrow$ (dalam menganalisa secara kualitatif dapat dianalisa hubungan dengan ayah)

- Rangsang detail yang bisa muncul :

1. Bagian/area atas, seperti ular, wanita terjun.

2. Area sisi / samping, seperti sepatu bot.

3. Area paling atas kecil dan area tengah agak ke bawah, biasanya / seringkali direspon sebagai organ seksual.

- Kadang-kadang, kartu ini merangsang munculnya jawaban-jawaban yang mengandung unsur tekstur,

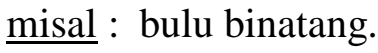




\section{KARTU V}

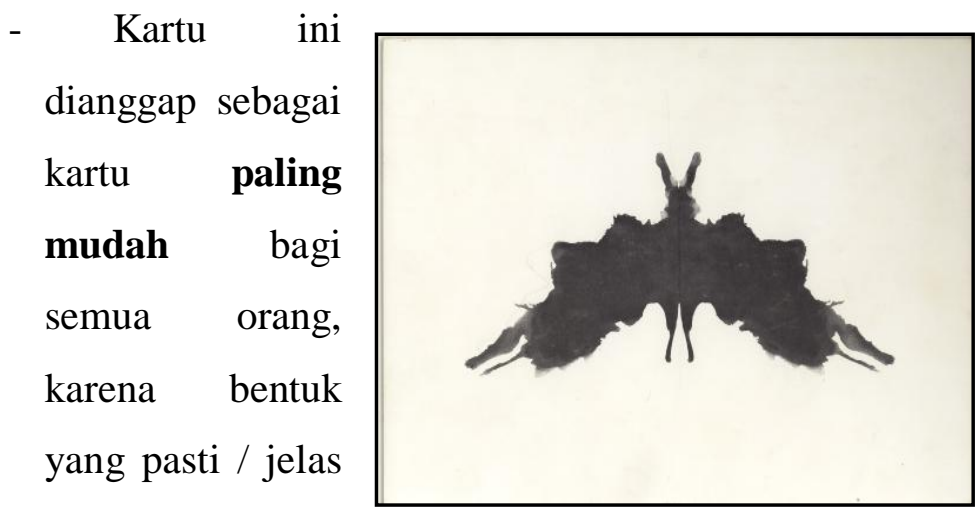

dan warna hitam

keseluruhan.

- Dapat digunakan untuk memancing minat / kemudahan subyek didalam merespon gambar bila subyek kesulitan merespon gambar I.

- Merangsang respon secara keseluruhan sebagai, binatang bersayap, misal : kelelawar atau kupu-kupu, dan biasanya dalam bentuk gerakan.

- Dalam bentuk detail, bagian samping tampak seperti : kepala binatang atau tungkai manusia.

- Memancing adanya " black - shock" yaitu individu merasa terganggu / ada ham-batan / perasaan tidak enak oleh warna hitam pada kartu, yang berakibat subyek butuh waktu lama untuk 
memberi jawaban, atau bahkan tidak muncul jawaban.

- Kartu V disebut kartu reality testing / common sense

\section{KARTU VI}

- Kartu VI ini

dikenal sebagai

kartu seks (sex

card), karena

bagian atas

kartu seringkali

diinterpretasikan

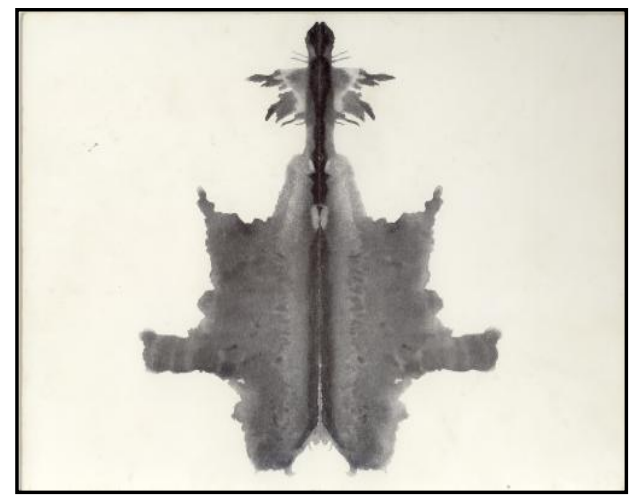

se bagai simbol phallic, dan bagian bawah sebagai

symbol sex wanita.

- Respon-respon yang muncul, antara

lain respon yang mengandung un-

sur shading-shading yang ada pada kartu ini misal :

permadani berbulu.

- Yang sering muncul : patung keramat, tiang lentera

$\rightarrow$ karena shading- nya seperti kayu.

- Kartu ini seperti kartu IV sering menggangu individu yang merespon karena shading-shading yang 
dimilikinya sering dikombinasi dengan area-area seksual pada kartu ini.

- Sering direspon keseluruhan, kalaupun direspon sebagaian secara terpisah antara bagian atas dari bawah.

\section{KARTU VII}

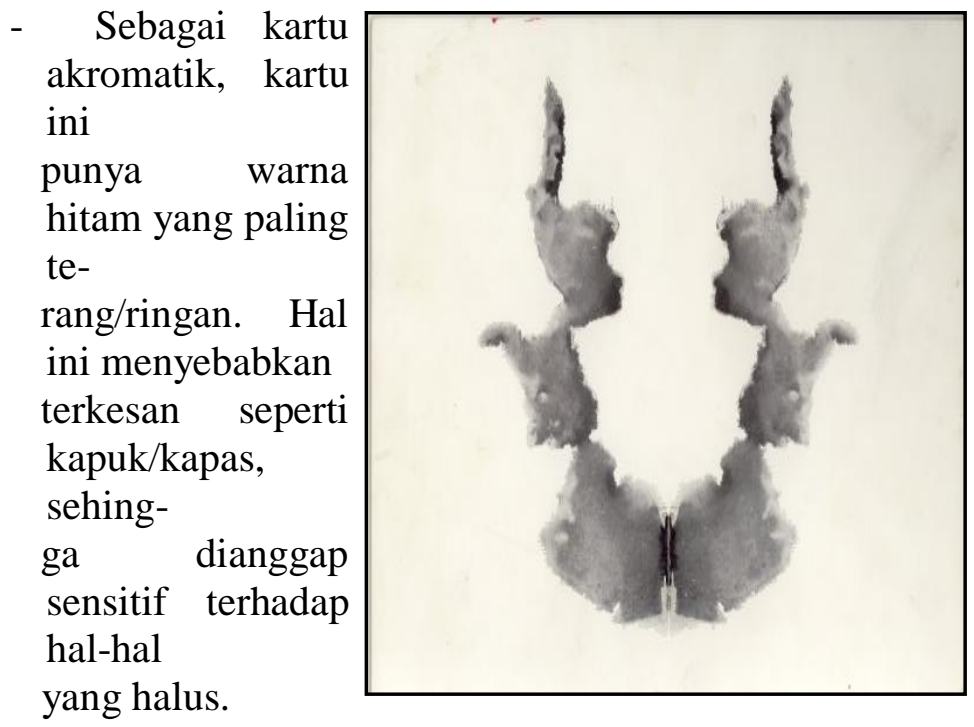

- Selain itu kartu ini karena kehalusan-

nya, kartu ini punya area (yaitu area tengah bawah) yang sering dikesankan sebagai organ seks.

- Disebut sebagai kartu ibu (mother card), karena :

$\rightarrow$ Pada anak-anak (4-9 th), area tengah bawah ini sering direspon sebagai rumah dengan asap- 
asapnya yang keluar dari cerobong asap rumah. Jawaban ini merupakan simbol keibuan.

$\rightarrow 2$ bagian gambar di atas, sering direspon sebagai sosok wanita atau anak-anak. Jawaban ini dianggap jawaban yang berkaitan dengan feminitas dan kelembutan

- Kartu ini sering menimbulkan respon keseluruhan, sering berkenaan dengan figur manusia dalam gerakan.

- Selain kapas, respon lain antara lain : awan, asap atau peta.

\section{KARTU VIII}

- Kartu ini

merupakan kartu

berwarna secara

keseluruhan dengan

penye-

baran warna yang

terpisah-pisah,

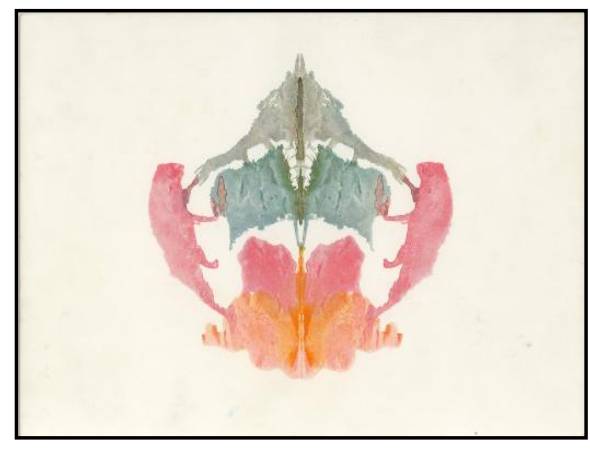

yaitu : Abu-abu kebiruan atau abu-abu kehijauan di

atas, biru di tengah, warna pink dan orange di bawah

dan 2 warna pink di samping.

- Warna-warna ini dikaitkan dengan 
warna afektif, yaitu berkaitan dengan

suasana hati.

- Pada subyek yang tidak berhasil atau

menolak memberi respon pada kartu

ini akan memunculkan indikasi ada-

nya :

1. kesulitan didalam menghadapi situasi

yang membangkitkan emosi

2. kesulitan didalam emotional involvement (terlibat secara emosi) dengan orang lain.

- Jawaban-jawaban yang muncul diantaranya :

1. Bagian yang menonjol adalah bagian pinggir, yang sering di-kesankan sebagai gambar binatang yang sedang bergerak, misal : tupai memanjat pohon, dsb.

2. Selain secara terpisah, maka respon secara keseluruhan biasanya / sering dikesankan sebagai : emblem / lencana. 


\section{KARTU IX}

- Dianggap sebagai kartu tersukar

karena

bagian-

bagiannya tidak ter-

pisah dan warna-

warna yang ada

bercampur/overlap.

$\rightarrow$ Ini menyulitkan individu untuk

merespon secara keseluruhan

(W), bahkan respon-respon yang

detail $(\mathrm{D}, \mathrm{d})$, sehingga kartu ini lebih sering direject / ditolak.

- Respon-responnya antara lain :

$\rightarrow$ Sangat bervariasi, karena gambar kartu ini tergolong paling sulit untuk direspon.

$\rightarrow$ Kalaupun direspon, respon yang muncul biasanya (tidak sering) antara lain :

1. Bagian atas : tukang sihir (wanita)

2. Area pink bawah : kepala manusia

3. Kalau gambar dibalik : letusan (gunung) 
- Kartu IX disebut kartu penyesuaian sosial (social djustment)

KARTU X

- Kartu ini

merupakan

kartu yang

paling ramai

sifatnya (penuh

warna-

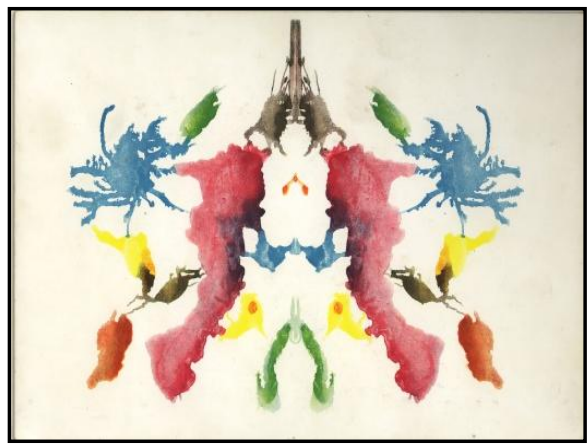

warni), seperti : Palet yang penuh warna.

- Pembagian warnanya yang menye-

bar dibanding kartu-kartu lain, maka hal ini merangsang individu

untuk merespon secara bagian /

detail, jarang secara keseluruhan (whole).

- Kartu ini disebut sebagai kartu intelektual, karena mewakili kemam-puan inteligensi seseorang, dan ini muncul pada subyek yang mampu memberi respon W dengan kualitas baik.

- Respon yang muncul, misal :

1. Secara bagian / detail :

- Ulat / ular hijau (pada area hijau bawah)

- Kepiting (pada area biru samping) 
- Kepala kelinci (area kecil diantara area hijau bawah), dsb.

2. Secara keseluruhan / whole :

- Palet pelukis

- Pandangan / pemandangan bawah air.

- Sering muncul respon-respon tentang binatang, sedangkan manusia jarang terespon, kecuali pada area besar pink di tengah agak samping, depresi sebagai manusia sedang menghisap sesuatu.

\section{Kesimpulan}

Tes Rorschach dikembangkan oleh Hermann Rorschach, dan diterbitkan pertama kali pada tahun 1921. Tes Rorschach ini menggunakan bercak tinta sebagai alat bantu didalam usaha menegakan diagnosis kepribadian secara menyeluruh.

Tes Rorschach juga sering digunakan untuk mendeteksi masalah-masalah gangguan psikologis, seperti : gangguan pikiran, terutama dalam kasus dimana pasien enggan menyampaikan proses berpikir mereka secara terbuka.

Tes Rorschach di awal penyusunannya mengalami perkembangan. Sejarah perkembangan tes Rorschach ini meliputi masa sebelum terbentuknya tes Rorschach (mulai tahun 1857), saat terbentuknya tes Rorschach (tahun 1921), dan sesudah terbentuknya tes Rorschach (1924). 
Tes Rorschach telah memenuhi standardisasi karena alat tes ini telah melewati proses penelitian dan eksplorasi selama 10 tahun, yang dilakukan Hermann Rorschach terhadap pasienpasien di Rumah Sakit tempat Rorschach menjabat sebagai kepala psikiater.

Penggunaan Rorschach secara luas telah menghasilkan validitas klinis yang tidak selalu bisa dibuktikan dengan validitas statistik.

Demikian juga dengan reliabilitas tes Rorschach, sudah terbukti reliabel, karena sudah diuji berulang kali.

Kartu Rorschach terdiri dari 10 buah kartu yang bisa dipakai dengan ukuran 6.15 x 9.50 inci, hasil dari seleksi dari ribuan kartu bercak tinta yang dibuat oleh Hermann Rorschach.

Kesepuluh kartu Rorschach dibagi menjadi 2 kolompok yaitu kelompok kartu akromatik (kartu ke 1, 4,5,6,7), dan kartu kromatik (kartu ke 2,3,8,9,10).

Masing-masing kartu Rorschach memiliki karakteristik, yang mewakili aspek kepribadian yang bisa diungkap.

Kartu 1, disebut kartu penyeuaian diri pada situasi baru, karena kecepatan dan kemampuan subyek didalam memberikan respon menunjukkan daya adaptasi. 
Kartu 2, disebut kartu agresi, karena merangsang munculnya respon yang mewaliki adanya potensi agresivitas.

Kartu 3, disebut kartu manusia. Jika tidak muncul jawaban manusia, patut dicurigai kalau subyek sebenarnya mempunyai kesulitan dalam penyesuaian dengan orang lain.

Kartu 4, disebut kartu ayah, karena dapat menggali sikap individu terhadap "otoritas"

Kartu 5, disebut kartu reality testing / common sense

Kartu 6, disebut kartu seks , karena bagian atas kartu seringkali diinterpretasikan sebagai simbol phallic, dan bagian bawah sebagai simbol seks wanita.

Kartu 7, disebut kartu ibu, karena jawaban-jawaban yang muncul sering berhubungan dengan simbol keibuan/feminitas/kelembutan.

Kartu 8, disebut kartu berwarna secara keseluruhan dengan penyebaran warna yang terpisah-pisah, dan warna-warna ini dikaitkan dengan warna afektif, yaitu berkaitan dengan suasana hati.

Kartu 9, disebut kartu penyesuaian sosial (social djustment)

Kartu 10, disebut kartu intelektual, karena mewakili kemampuan inteligensi seseorang 


\section{Latihan soal :}

1. Jelaskan bagaimana perkembangan penyusunan dan pemanfaatan tes Rorschach

2. Tes Rorschach bisa digunakan untuk tujuan apa saja ? Jelaskan!

3. Sebagai suatu instrumen, apakah tes Rorschach memenuhi kriteria standardisasi ? validitas ? reliabilitas ? Jelaskan!

4. Jelaskan karakteristik masing-masing kartu Rorschach !

5. Apa manfaat karakteristik yang dimiliki masing-masing kartu Rorschach ?

Referensi :

Beck, Samuel J., Beck Anne G., Levitt, Eugene E., \& Molish, Herman B. Rorschach's Test-I. Basic Processes. Grune \& Stratton, New York \& London, 1961.

Klopfer, B \& Davidson, H.H, 1962. The Rorschach Technique. An Introduction Manual. Harcourt, Brace, \& World, Inc., New York, USA.

Subandi \& Ratna Wulan, 2005. Tes Rorschach. Administrasi dan Skoring. Fakultas Psikologi UGM, Yogyakarta. 


\section{BAB IV \\ ADMINISTRASI TES RORSCHACH}

\section{Kemampuan Akhir Yang Direncanakan :}

Setelah mempelajari bab ini, diharapkan mahasiswa mampu memahami dan melaksanakan administrasi

tes Rorschach

Administrasi tes dimaksudkan untuk memenuhi standardisasi situasi pelaksanaan tes sehingga tester dapat memperhatikan respon-respon yang diberikan testee, mengingat stimulus tes, yang berupa gambar bercak tinta, bersifat ambigius, dan tidak terstruktur. Stimulus seperti ini mampu mengungkap kepribadian hanya jika suasana tes terkontrol.

Pada bagian ini akan dibahas tahap persiapan sebelum tes dilaksanakan dan tahap pelaksanaan tes secara detil. 


\section{IV.1 Persiapan Tes}

Selain itu hasil tes sangat ditentukan oleh seberapa siap tester melaksanakan tes Rorschach ini, sehingga seorang tester harus mempersiapkan segala sesuatu yang berkaitan dengan pelaksanaan tes.

Sebelum melaksanakan tes, seorang tester harus melakukan persiapan dengan cara memperhatikan halhal yang bisa mempengaruhi proses pelaksanaan tes. Persiapan yang harus dilakukan seorang tester adalah

(1) Persiapan untuk diri tester sendiri, yang meliputi :

a. Mengatur materi tes Rorschach berupa kartukartu tes Rorschach.

Kartu-kartu disusun secara terbalik/tertelungkup, yaitu : kartu I letaknya paling atas dan kartu X paling bawah dan gambar tidak terlihat, hanya nomor kartu saja yang terlihat karena posisi kartu dibalik. Sebaiknya meletakkan kartu kartu tersebut si sebelah (kiri atau kanan) tester.

b. Menyiapkan sarana lain yang diperlukan seperti : lembar kerja (yang digunakan saat tes terdiri dari lembar jawaban, peta lokasi), alat tulis, stopwatch, kertas kosong.

c. Mengatur tempat duduk untuk pelaksanaan tes. 
Posisi duduk bisa fleksibel ( berhadapan, bersebelahan, agak menyerong).

Sebagai pertimbangan : a) untuk orang timur, tampaknya duduk berhadapan atau bersebelahan tidak begitu mengganggu ; b) Exner mengatakan, bahwa jangan duduk berhadapan ; c) tester bisa duduk di sebelah testee/subyek tetapi agak ke belakang sehingga dapat sekaligus mengobservasi perilaku subyek (non verbal) saat tes berlangsung, mencatat semua ungkapan verbal secara lengkap (verbatim) tanpa mengganggu testee/subyek, dan subyek bisa bebas mengungkapkan jawaban atau memberi respon saat tes berlangsung.

(2) Menciptakan atmosfir tes yang alami.

a. Membuat rapport sebelum tes Rorschach diberikan.

Hal ini dimaksudkan agar hasil yang dicapai bisa maksimal. Ingat !, subyek akan merasa diterima apa adanya sehingga bisa secara bebas mengekspresikan perasaannya dan memberi respon secara leluasa. Dengan situasi seperti ini spontanitas didalam memberi respon/jawaban 
yang kita minta dari testee bisa tercapai. Pembuatan anamnesa bisa dilakukan saat pembuatan rapport ini.

b. Mengupayakan kondisi (fisik, psikis, ruangan, dsb.) optimal yang memungkinkan kenyamanan subyek.

Dengan demikian dapat disimpulkan bahwa tugas tester adalah menciptakan situasi rileks dan tetap terkontrol agar hasil yang diharapkan muncul, yaitu subyek merasa rileks dan dapat merespon tanpa tertekan. (ingat : respon yang muncul tanpa adanya pengalaman sebelumnya). Untuk itu perhatikan beberapa faktor :

1. Situasi tes

Situasi tes sendiri ditentukan oleh subyek, tester dan keadaan pada saat pengetesan.

- Subyek harus dibuat kerasan / tidak curiga sekaligus bisa memahami apa yang harus dikerjakan.

2. Suasana antara testee dan tester dan kelengkapan alat 
- Tester harus mengadakan pendekatan dengan subyek, sehingga subyek percaya pada tester.

- Tester harus berusaha membentuk situasi rileks / tenang sehingga respon yang timbul terjadi secara spontan / tidak terpaksa.

- Keadaan harus tenang, cahaya cukup dan jangan ada gambar-gambar di ruangan

3. Instruksi kepada subyek

- Seluruh kartu harus sudah tersedia lengkap dalam susunan yang benar sehingga saat tes berlangsung subyek bisa melihat tester memang siap melaksanakan tes.

- Selain kartu harus juga sudah tersedia lembar individu Record Blank $\rightarrow$ untuk menandai areaarea yang direspon subyek ( = A location Chart ) ; 1 lembar untuk penjelasan respon subyek ; Stopwatch ; dan alat tulis

4. Instruksi

- Tidak ada standart, hanya pertimbangan :

a. Usia

b. Pengalaman

c. Latar belakang budaya 
Oleh karena itu harus dipahami inti instruksi yang harus disampaikan kepada subyek / testee.

\section{IV.2. Tahap Pelaksanan Tes Rorschach}

Tahap pelaksanaan tes Rorschach ada 4 (empat), tetapi yang harus dilakukan adalah tahap I dan tahap II. Sedangkan tahap II dan tahap IV tidak selalu dilakukan tergantung respon yang dihasilkan oleh testee. Hal ini akan dijelaskan pada tahap III dan tahap IV di halaman selanjutnya.

\section{Tahap I : Performance Proper}

Tahap ini dilaksanakan untuk mendapatkan respon subyek berupa jawaban-jawaban yang diberikan saat tes berlangsung. Untuk memperoleh jawaban yang maksimal, yang memang benar-benar mewakili potensi subyek yang sebenarnya maka tugas tester (seperti dijelaskan di atas) harus diterapkan pada tahap ini.

Apa yang harus dilakukan tester saat tes berlangsung hanya mencatat seluruh jawaban yang diberikan subyek.

Tahap ini terdiri dari 2 langkah :

1. Tahap ini dimulai dengan memberi instruksi. 
Seperti dijelaskan sebelumnya, tidak ada instruksi standart. Hanya dalam instruksi ini inti yang harus disampaikan adalah :

a. Bagaimana kartu ini mula-mula terbentuk

b. Pada subyek akan ditunjukan 10 kartu secara bergantian

c. Tugas yang harus dilakukan subyek

d. Jaminan tidak ada jawaban yang salah

Contoh instruksi :

"Saya akan menunjukan kepada saudara beberapa gambar. Gambar-gambar ini sebenarnya terbuat dari percikan tinta yang kemudian dilipat sehingga menghasilkan gambar-gambar yang simetris (sama sisi kiri dan kanan) seperti yang akan saudara lihat nanti.

Saya akan menunjukkan sepuluh kartu bergambar. Saya akan berikan satu persatu gambar-gambar tersebut.

Saya ingin agar saudara menyebutkan / menyatakan apa saja yang bisa saudara lihat dari gambar tersebut sesegera mungkin atau secara spontan

Tidak ada jawaban yang salah. Semuanya benar, jadi jangan takut mengutarakan jawaban / respon."

Tambahan instruksi :

- Kemungkinan pertanyaan-pertanyaan yang muncul dari subyek, misal : 
"Berapa jawaban yang harus diutarakan ?"

- Jawab : “ Masing-masing orang bisa melihat banyak hal dalam satu kartu. Andapun bisa melakukan hal-hal yang sama walaupun jawabanya berbeda-beda. Terserah saudara ".

- Tambahan kalau perlu :

" Orang-orang lain bisa melihatnya dengan banyak cara, dari sisi manapun. Kalau saudara menginginkan hal yang sama boleh saja"

- Jika subyek hanya memberi 1 respon /1 jawaban pada kartu I, tester bisa mengatakan :

" Beberapa orang bisa melihat banyak hal dalam 1 kartu, kalau saudara bisa juga coba utarakan saja yang terlihat "

- Jika subyek kelihatan akan menjelaskan apa yang telah dilihat, tester bisa menghentikannya dan katakan bahwa : subyek hanya diminta untuk menyebutkan apa yang dilihat saja.

- Jangan menyatakan :

" Saudara boleh melihat kartu selama yang diinginkan untuk me-yakinkan apa yang dilihat. “ 
2. Setelah memberi instruksi, tester mencatat semua respon yang secara spontan diutarakan oleh subyek pada setiap kartunya. Jangan memberi sugesti. Secara keseluruhan yang harus dicatat tester adalah

a. Respon subyek.

Respon (jawaban) subyek harus dicatat lengkap (secara verbatim) tanpa mengurangi satu kata sekalipun. Respon dicatat dalam lembaran jawaban (lebih baik dengan steno). Kalau akan direkam, minta ijin dulu.

b. Waktu yang digunakan subyek, yang meliputi :

1. Waktu reaksi (Reaction Time) : Waktu yang dihitung sejak kartu disajikan sampai respon 1 kali muncul.

2. Waktu respon total per kartu (Total respons time percard) : Jumlah waktu yang digunakan subyek menyebutkan jawaban-jawbannya pada tiap kartu

3. Waktu respon total (Total respon time) : Jumlah waktu yang digunakan subyek selama performance proper. 
c. Posisi kartu : yaitu posisi kartu saat dipegang subyek.

Pencatatan ini memudahkan tester/subyek pada saat inquiry (mengi-ngatkan posisi bagaimana sehingga respon-respon tersebut muncul). Ada beberapa posisi yang muncul :

$$
\begin{aligned}
& \wedge: \text { normal (posisi awal kartu diberikan) } \\
& \vee \quad: \text { terbalik } \\
& >\text { : putar } 90^{\circ} \text { kiri } \\
& <: \text { putar } 90^{\circ} \text { kanan } \\
& \text { ๑ : diputar }
\end{aligned}
$$

d. Observasi tester :

Hal-hal yang diobservasi, misal : keluhan atau tingkah laku-laku tertentu dsb., yang bisa mendukung hasil pengetesan.

\section{Tahap II : Inquiry}

Tahap dimana tester menggali keterangan lebih jelas atas respon-respon yang telah diberikan subyek/testee pada saat tahap performance proper. Tester meminta keterangan-keterangan dari subyek sebanyak mungkin tentang respon-responnya. Makin lengkap makin 
membantu ketepatan scoring, juga bisa melihat / mengetahui dengan tepat taraf intelektual individu. Langkah-langkah dalam tahap II, meliputi :

1. Tahap ini dimulai dengan memberi instruksi.

Tidak ada instruksi standart, ada 2 hal yang harus diperhatikan :

a. Jangan sampai subyek merasa bahwa jawaban / responnya ditentang.

b. Jangan sampai subyek berprasangka sehingga informasinya tidak me-ngena.

Secara umum contoh instruksi yang bisa diberikan adalah :

"Setelah melihat kartu-kartu tadi akan kita lihat lagi kartu-kartu tersebut. Saya ingin saudara menjelaskan lebih jauh respon-respon yang saudara munculkan. “

2. Tahap mengajukan pertanyaan .

Pertanyaan yang diajukan dimaksudkan untuk memperoleh informasi lebih jauh apa yang sudah diterangkan testee pada tahap awal. Pertanyaannya meliputi pertanyaan yang menyangkut : 
a. Lokasi (= area bercak yang memunculkan jawaban testee).

Bisa ditanyakan :

“ Coba tunjukkan area mana yang anda gunakan sehingga anda me-nangkap kesan seperti ............"

Pertanyaan diajukan bersamaan dengan tester menunjukkan kembali gambar kartu Rorschach satu persatu kepada testee, mulai dari respon pertama kartu I sampai respon terakhir kartu X. Sesudah testee menunjukkan area yang dimaksud, maka selanjutnya tester menggambar area yang dimaksud testee di lembar peta lokasi (location chart).

b. Determinan ( $=$ dasar pemikiran testee memberikan jawaban, apa yang menyebabkan bercak yang dilihat testee menimbulkan kesan berupa jawaban yang diberikan testee).

Untuk mengetahui hal itu, tester bisa bertanya :

“ Ceritakan bagaimana anda bisa mempunyai kesan bercak itu se-bagai / seperti 
Setelah testee memberi penjelasan, tester segera menulis penjelasan tersebut di lembar jawaban (record blank) yang tersedia.

Asumsi pertama sewaktu melakukan inquiry untuk "alasan respon" adalah bahwa setiap respon menunjukkan "Form" (bentuk), misal : "gambar ini seperti seorang wanita".

a. Kalau jawaban berupa mahluk hidup seperti contoh di atas, maka ada kemungkinan akan ditambah unsur "movement" (gerakan), misal : "Wanita sedang melambai".

b. Kalau ada kesan digunakannya unsur "shading", seperti : "Wanita yang menggunakan baju transparan", maka kemungkinan diberi skor yang berisi "shading".

Dengan banyaknya kemungkinan tersebut, maka tester bisa bertanya lebih dalam asal masih ada relevansinya dengan jawaban yang diberikan. Misal :

- Form : Kalau konsepnya definit, harus diyakini kualitas bentuk.

Contoh respon : "kelelawar". 
Pertanyaan yang bisa diajukan :

"Sayapnya dimana ?", "Yang ini apanya ?" (sambil menunjuk area tertentu dari area respon kelelawar).

Semua keterangan testee dicatat (secara verbatim) pada lembar jawaban. Pertanyaanpertanyaan lanjutan yang sifatnya untuk memperoleh informasi lebih detil bisa dilakukan kalau tester merasa kurang yakin dengan informasi yang diperoleh sebelumnya. Bila informasi testee sudah bisa diskor maka tidak perlu lagi menggali informasi lanjutan, karena bisa membuat testee merasa jawabannya salah atau ditentang.

Pertanyaan harus dilakukan per respon, satu per satu, artinya setiap respon/jawaban yang diberikan testee akan ditanya lokasi dan alasan jawaban. Satu respon ditanya lokasinya, dilanjutkan pertanyaan deter-minant (alasan jawaban/respon). 
Untuk respon selanjutnya, dilakukan hal yang sama. Demikian seterusnya sampai semua respon ditanya lokasi dan determinant-nya

Ada beberapa hal yang harus diperhatikan tester pada proses pencatatan di tahap inquiry :

1. Penggambaran lokasi respon dengan cara memberi batas lingkaran area mana yang mewakili respon yang dibuat testee pada tahap I, contoh : kartu VIII

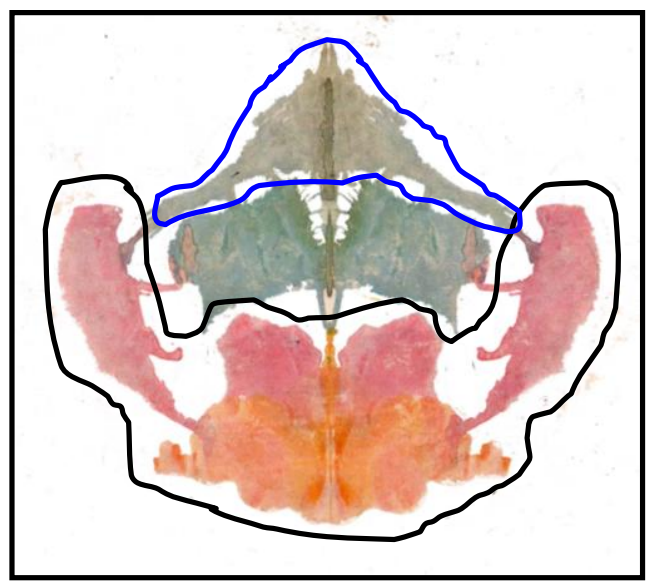

2. Pertanyaan tester diberi tanda $T=$ tanya, demikian juga dengan jawaban testee diberi tanda $\mathbf{J}=$ jawab , contoh : kartu VIII di atas P.P INQ. : 
Matahari terbenam $\mathbf{J}$ : Warnamya ini.

Seluruhnya,

terutama warna

jingga di bawah

ini (sisi luar dan

bawah) seperti

awan.

$\mathrm{T}$ : Bagaimana bercak ini bisa kelihatan seperti awan?

$\mathrm{J}$ : Warna ini, karena matahari

terefleksi

padanya.

3. Bila muncul respon baru pada tahap ini, maka respon ditulis di kolom inquiry dengan menuliskan tanda "add" dan sekaligus di-inquiry,

contoh : kartu VIII

P.P

INQ. :

Matahari terbenam

$\mathrm{J}$ : Warnanya ini. Seluruhnya, terutama warna jingga di bawah ini (sisi luar dan bawah) seperti awan.

T: $\quad$ Bagaimana bercak ini bisa 
kelihatan seperti awan?

$\mathrm{J}$ : Warna ini, karena matahari terefleksi padanya.

Add : Seperti bentuk gunung dilihat dari jauh.

T: Apa yang mengesan kan seperti gunung?

J: Bentuknya yang meruncing ke atas (biru atas)

4. Kalau mendapatkan jawaban yang ditolak/disangkal atau tidak dikenali oleh testee sendiri tetap diskor.

Dari jawaban-jawaban ini dapat diketahui :

1. Lokasi

2. Determinan

3. Kontent / isi jawaban

4. Populer-originalnya jawaban

5. FLR ( nilai ketepatan bentuk ) 


\section{Tahap III : Analogy}

Tahap ini sering disebut juga dengan " follow-up inquiry ". Tahap ini tidak selalu harus dilakukan seperti tahap I dan II, melainkan hanya dilakukan pada kondisi tertentu, yaitu : bila testee sudah mampu memberi respon - respon tertentu namun jumlah atau responnya (produktivitasnya) sangat sedikit (biasanya hanya satu respon), terutama respon yang memiliki skor : M (human movement), FM (animal movement), ( $\mathrm{Fc}, \mathrm{cF}, \mathrm{c})$ atau textural, $(\mathrm{FC}, \mathrm{CF}, \mathrm{C})$ atau chromatic color, dan respon $\mathrm{P}$ (populer).

Langkah-langkah tahap Analogy :

1. Instruksi

Sifat instruksi sudah lebih langsung, misal : testee hanya bisa membuat respon movement pada kartu III, maka instruksi yang bisa diberikan adalah :

" Di sini anda dapat melihat seorang wanita yang sedang mem-bungkuk. (sambil memperlihatkan kartu III) Apakah di kartukartu yang akan saya tunjukkan nanti, anda bisa melihat menusia seperti itu?" 


\section{Penggalian}

Setelah instruksi, tester menunjukkan kartu-kartu yang merangsang testee bisa melihat manusia, dimulai dari kartu I sampai X (kecuali kartu III).

$\underline{\text { Keterangan }}$ : respon-respon yang dikemukakan testee pada tahap ini tidak diskor, melainkan hanya dicatat atau dimasukkan dalam hasil observasi. Kemudian, secara kualitatif diinterpretasi dengan menggunakan interpretasi kualitatif.

\section{Tahap IV : Testing The Limit}

Tahap ini merupakan prosedur untuk menguji apakah testee pada dasarnya mampu memproduksi respon-respon dengan konsep tertentu, mampu menggunakan lokasi tertentu, dan mampu menggunakan determinan tertentu ?

Prosedur testing the limit diberikan saat testee tidak mampu menghasilkan respon-respon sebagai berikut :

1. Hanya mampu memberi jawaban $\mathrm{W}$, atau hanya mampu memberikan jawaban dengan lokasi D. 
- Untuk itu testee didorong ( dengan diberi tahap testing the limit ) untuk mencoba membuat respon dengan menggunakan lokasi D (bila hanya mampu memberi jawaban $\mathrm{W}$ ), demikian sebaliknya.

2. Kemampuan mempersepsi human content ( $\mathrm{H}$ ) dan memproyeksikan gerakan pada manusia ( $\mathrm{M}$ ).

3. Kemampuan testee untuk mengintegrasikan Form ( F ) dan Color ( C ).

- Pada kartu kromatik, terutama kartu III dan X, kartu VIII, kartu IX

4. Kemampuan untuk memberikan respon nuansa shading

- Pada kartu akromatik, terutama kartu IV ddan VI

5. Kemampuan mempersepsi dan berpikir konvensional, yaitu : memproduksi respon populer ( P ).

- untuk memastikan apakah tidak mampu memproduksi respon $\mathrm{P}$ karena tidak mampu atau karena tidak mau mengungkap hal-hal yang mudah dilihat ( $\mathrm{P}$ ). 
6. Melihat gerakan binatang, terutama pada kartu VIII

Biasanya prosedur ini digunakan pada testee yang :

1. tidak mantap dalam memberikan respon-respon karena cemas saat tes.

2. bingung dengan apa yang dimaui oleh tes ini

3. menghasilkan respon yang miskin atau kurang memadai kualitasnya.

Instruksi pada tahap analogy sudah bersifat langsung dan mengarahkan, misal : untuk mengarahkan munculnya jawaban $\mathrm{D}$, maka instruksi yang bisa disampaikan :

“ Kadang-kadang orang lain hanya menggunakan sebagian dari bercak tinta yang ada di setiap kartu, tidak harus seluruh bercak digunakan sekaligus. Dapatkah anda melakukan hal itu juga? "

Langkah penggaliannya :

1. Kemudian ditunjukkan kartu-kartu Rorschach mulai dari kartu I sampai $\mathrm{X}$.

2. Kalau cara ini gagal, tester langsung menunjukkan bercak-bercak unusual detail. 
3. Kalau masih gagal, tester menunjukkan lokasi usual detail yang berisi jawaban populer, misal : kartu X (kepiting), dsb.

4. Kalau testee masih gagal, maka tester mengajukan beberapa respon populer dan mengatakan "Kalau di bagian ini orang lain melihat sebagai ......... (respon populernya), bagaimana dengan anda? "

5. Untuk orang yang tidak mampu memberikan respon populer ( $\mathrm{P}$ ), tester bisa memilih 2 atau 3 gambar. Kemudian memperlihatkan salah satu gambar tersebut dengan mengatakan " Kita hampir selesai, tetapi ini ( memperlihatkan kartu ) lihatlah sekali lagi. Kadang-kadang orang melihat ............ (respon populernya) peda kartu ini. Bisakah anda melihat ......... (respon populer yang tadi disebut) pada kartu ini ? “

Teknik yang digunakan pada pelaksanaan testing the limit :

1. Prosedur asosiasi bebas :

Meminta testee memberi respon asosiasi bebas terhadap respon kartu-kartu Rorschach tertentu, 
terutama yang menimbulkan kejutan (shock), baik berupa "color shock" maupun "shading shock"

2. Teknik pembentukan konsep :

Meminta testee untuk mengelompokkelompokkan kartu sesuai dengan cara nya sendiri. Ia bisa membaginya berdasar isi (content), sikap afektif (affective attitude), perbedaan warna, perbedaan bentuk (form), dsb.

3. Prosedur suka - tidak suka :

Meminta testee mengambil kartu yang paling disukai dan kemudian mengambil satu kartu yang paling tidak disukainya. Kemudian menanyakan alasannya mengapa paling suka pada satu kartu tertentu dan paling tidak suka pada satu kartu yang lainnya.

Keterangan :

- sama halnya dengan inquiry, maka respon yang dihasilkan pada tahap ini tidak diskor, cukup dicatat.

\section{Kesimpulan}

Sebelum melaksanakan tes, seorang tester harus melakukan persiapan, meliputi : a. Persiapan untuk diri tester sendiri ; b. Menciptakan atmosfir tes yang alami. 
Pada tahap persiapan perlu memperhatikan beberapa faktor : 1. Situasi tes ; 2. Suasana antara testee dan tester dan kelengkapan alat ; 3. Instruksi kepada subyek

Tahap pelaksanaan tes Rorschach ada 4 (empat), yaitu : tahap I tahap performance proper ; tahap II tahap Inquiry ; tahap III tahap Analogy ; tahap IV tahap testing the limit. Tahap yang harus dilakukan adalah tahap I dan tahap II. Sedangkan tahap II dan tahap IV tidak selalu dilakukan tergantung respon yang dihasilkan oleh testee.

Tahap I : Performance Proper adalah tahap untuk mendapatkan respon subyek berupa jawaban-jawaban yang diberikan saat tes berlangsung.

Tahap II : Inquiry yaitu tahap dimana tester menggali keterangan lebih jelas atas respon-respon yang telah diberikan subyek/testee pada saat tahap performance proper.

Tahap III : Analogy, atau tahap "follow-up inquiry ", yang dilakukan saat testee sudah mampu memberi respon respon tertentu namun jumlah atau responnya (produktivitasnya) sangat sedikit (biasanya hanya satu respon), terutama respon yang memiliki skor : $\mathrm{M}$ (human movement), FM (animal movement), (Fc, cF, c) atau textural, (FC, $\mathrm{CF}, \mathrm{C}$ ) atau chromatic color, dan respon $\mathrm{P}$ (populer). 
Tahap IV : Testing The Limit, yang merupakan prosedur untuk menguji apakah testee pada dasarnya mampu memproduksi respon-respon dengan konsep tertentu, mampu menggunakan lokasi tertentu, dan mampu menggunakan determinan tertentu ?

\section{Latihan soal :}

1. Jelaskan apa yang harus dilakukan sebelum melaksanakan tes Rorschach!

2. Ada berapa tahap pelaksanaan tes Rorschach ? Jelaskan masing-masing ta-hapnya !

3. Jelaskan apa syarat diperlukannya melaksanakan tahap Analogy!

4. Jelaskan mengapa perlu melaksanakan tahap Testing the limit, dan apa yang di-lakukan pada tahap ini !

\section{Referensi :}

Klopfer, B \& Davidson, H.H, 1962. The Rorschach Technique. An Introduction Manual. Harcourt, Brace, \& World, Inc., New York, USA.

Subandi \& Ratna Wulan, 2005. Tes Rorschach. Administrasi dan Skoring. Fakultas Psikologi UGM, Yogyakarta. 


\section{BAB V \\ S K O R I N G}

\section{Kemampuan Akhir Yang Direncanakan :}

Setelah mempelajari bab ini, diharapkan mahasiswa mampu memahami macam-macam skor untuk setiap respon yang diberikan testee

Skoring ini bertujuan untuk mengklasifikasikan respon-respon yang dibuat subyek kedalam aspek-aspek materi bercak tinta yang berbeda. Pemberian skor ini sendiri merupakan cara untuk mengetahui bagaimana testee melakukan pendekatan terhadap masalah yang terwakili pada bercak tinta yang memiliki ciri tidak terstruktur. Selain bisa juga untuk menilai apakah respon testee tergolong akurat atau tidak.

Tiap aspek punya simbol skor ; sehingga respon subyek yang punya karak- teristik yang sesuai akan termasuk dalam kategori simbol skor tersebut, misal : 


\begin{tabular}{|c|c|}
\hline Respon/jawaban & skor \\
\hline $\begin{array}{l}\text { Kartu V (menggunakan seluruh } \\
\text { bercak) : } \\
\text { "Burung yang sedang terbang" }\end{array}$ & $\begin{array}{c}W-F M-A- \\
1,5\end{array}$ \\
\hline
\end{tabular}

Ada 5 kategori dalam skoring respon yang diberi testee pada kartu Rorschach :

1. Location : Daerah mana dari kartu yang direspon.

2. Determinant: Bagaimana kualitas dari responnya

3. Content : Apa isi responnya / tentang apa isi responnya

4. Populer-Original : Apakah respon subyek termasuk respon-respon yang populer atau jarang terjadi

5. Form Level Rating : Ketepatan (akurasi) konsep yang dilihat. Apakah jawaban / konsep tersebut sesuai dengan area yang digunakan ?

Mengapa aspek-aspek tersebut (5 aspek di atas) perlu diskor? Seperti dijelaskan di atas aspek-aspek tersebut memberi petunjuk tentang segi-segi yang penting dari kepribadian yang akan diungkap. Jawaban yang diberikan subyek merupakan hasil persepsi subyek terhadap bercak tinta (ink-blot) yang dihadapi.

Suatu respon dianggap sebagai jawaban yang independent , yang merupakan ide-ide yang jelas dengan menggunakan 
spesifik atau keseluruhan dari bercak tinta (ink-blot) dan biasanya hal ini kemudian dimulai sesuai dengan kualitas yang subyek berikan pada bercak tinta (ink-blot) tersebut.

\section{V.1. Jenis Respon}

Respon yang dibuat subyek ada 2 macam :

1 .

Main Response : jika

respon diberikan pada tahap performance-proper.

2. Additional Response : jika respon tersebut muncul pada tahap inquiry.

Additional response ini tidak hanya berupa responrespon baru, bisa juga berupa keterangan-keterangan baru. Keduanya muncul saat tahap inquiry.

Bagaimana skor diberikan untuk kedua jenis respon di atas?

a. Setiap main-response hanya mendapat 1 main-score untuk : location, deter-minant, content, $\mathrm{P}-\mathrm{O}$, dan FLR.

b. Ada kemungkinan main-response memperoleh additional-score karena subyek memberikan 
perincian atau spesifikasi pada saat performance proper maupun saat inquiry.

c. Kemungkinan lain timbulnya additional-score :

1. Bila respon pada tahap performance-proper ternyata di-reject oleh testee sendiri ketika inquiry. Dalam hal ini, skor-skor terhadap respon hanya pada bagian additional.

2. Bila testee memberi gambaran yang memperjelas konsep yang dibentuk pada saat performanceproper (agar konsep tampak lebih terinci / terorganisasi)

3. Bila testee memberi hubungan atau rincian baru pada tahap inquiry terhadap respon yang diberikan di tahap performance proper. Rincian atau spesifikasi baru ini biasanya untuk menambah FLR-nya, tetapi bila rincian ini malah merusak konsep/respon dan skornya menjadi lebih rendah atau berkurang.

4. Bila testee menggunakan kualitas-kualitas pada tahap inquiry kerena tidak sengaja. Biasanya, pada skor determinant. 


\section{V.2. Skoring}

\section{A. Lokasi (Location Score)}

Skoring untuk lokasi respon sesuai dengan area kartu yang digunakan testee untuk menggambarkan bentuk respon / jawaban yang muncul di tahap performance proper.

Ada 5 kategori skor untuk lokasi seperti yang dimaksud di atas :

1. Whole Respons, yang meliputi :

a. W (whole) : Bila subyek menggunakan keseluruhan area percikan tinta sebagai konsepnya, misal :

Kartu I : ini pasti kelelawar

Kartu II : dua orang wanita saling berhadapan pada saat menari

Kartu V : ini seekor kupu-kupu

b. (Cut-off Whole) : Bila subyek hampir menggunakan kese-luruhan area (2/3 dari keseluruhan area), misal :

Kartu II : dua anak anjing yang bersentuhan hidungnya (dua area merah kecil di atas tidak diikutkan) 
Kartu III : dua orang tukang sulap saling memegang sesuatu (area merah di atas diabaikan)

Kartu VI : kulit binatang (tanpa area di atasnya)

Catatan : pengabaian ( penghilangan sebagaian kecil bercak tinta) sering digunakan untuk menunjukkan jawaban secara lebih akurat. Namun tidak jarang ini juga sebagai indikator sifat terlalu kritis yang dimiliki testee.

c. DW (Confobulatory Whole) : Bila respon yang diberikan testee terkesan menggunakan keseluruhan gambar, tetapi alasannya (saat inquiry) hanya mengambil sebagian gambar (biasanya merupakan respon yang dengkal), misal :

Kartu I : testee menunjuk keseluruhan area : Seperti kelelawar, tetapi hanya melihat matanya saja. (subyek 
melihat area kecil tetapi dianggap

mewakili keseluruhan)

Catatan : hal ini terjadi karena ada kecenderungan over-generalisasi, sehingga berpengaruh pada skor FLR yang cenderung negatif.

\section{Large Usual Detail Response (D)}

Skor yang diberikan bila testee menggunakan sebagian besar area untuk konsep dan biasa dikesankan oleh orang, misal :

Kartu III : sepasang paru-paru (area merah tengah)

Kartu IV : seperti sepatu boot (area sisi / samping)

Kartu VIII : tampak seperti tikus (area merah / pink samping)

\section{Small Usual Detail Response (d)}

Skor yang diberikan kalau testee menggunakan area yang relatif kecil tetapi sering dikesankan / dilihat oleh orang, misal : 
Kartu V : kaki penari balet (gambar terbalik, area bawah)

Kartu VII : telinga kelinci (ujung paling atas)

Kartu IV : organ sex wanita (paling atas)

\section{Unusual Detail Respose (Dd)}

Skor yang diberikan bila area yang digunakan relatif kecil, dan jarang dikesankan orang. Skor ini meliputi :

a) dd (tiny detail) :

Hampir sama lokasinya dengan d, hanya jarang dikesankan orang. Penggunaan bercak yang seperti "pulau kecil" atau "semenanjung" yang dipisah oleh space, shading, atau color dari sisa bercak lainnya, misal :

Kartu VIII : janggut orang (area paling ujung kecil)

Kartu IX : tangan orang ( 2 area merah di dalam, bawah)

b) de (edge detail) :

Area pinggir bercak, kecil, dan jarang dilihat orang. Dalam inquiry, harus dipastikan bahwa skor "de" diberikan untuk penggunaan outline 
luar saja, tanpa menggunakan kontur bershading, misal :

Kartu V : seperti profil wajah (area

samping sayap)

Kartu VII : laki-laki mencium dahi wanita (area samping antara area tengah dengan bawah)

c) di (inside detail)

Area kecil di dalam gambar, jarang dikesankan orang. Penggunaan bagian dalam yang bershading tanpa menggunakan bagian pinggir sama sekali, misal :

Kartu IV : pasukan kerajaan seperti di Inggris (area atas di dalam agak ke kiri)

Kartu I : seperti kepala gajah kecil (area tengah kanan tampak agak keabuan dengan bercak hitam didalamnya) 
d) dr (rare detail)

Area-area yang tidak termasuk W, W, DW, D , d, de, dr, dd, di. Jadi lokasi / areanya bisa besar ataupun kecil, misal :

Kartu II : dua wanita sedang berbicara dari balik pagar (area merah atas ditambah area diantara area merah)

Kartu VI : wanita yang sedang memperhatikan kakinya (dilihat terbalik, area samping)

\section{White Space Response (S )}

Skor yang diberikan untuk respon dengan menggunakan area putih. Bisa berupa area putih sendiri atau merupakan bagian dari area lain.

Misal :

Kartu II : seperti lampu gantung ( S saja, tengah)

Kartu VII : pot bunga kuno (S saja, atas tengah)

Kartu I : topeng ( $\mathrm{S}$ bagian dari $\mathrm{W} \rightarrow \mathrm{W}, \mathrm{S}$ ) 


\section{Skoring Multiple Location}

Skor ini bisa diberikan bila :

a) Ada jawaban-jawaban independent pada saat performance proper, tapi saat inquiry digabung jadi 1 jawaban, misal :

Kartu III : dua orang suku afrika skor D di tengah-tengah kepiting : skor D mereka tampak sedang berkelahi dengan kepiting : skor $\mathrm{D} \rightarrow$ skor-nya menjadi W

b) Main-response menggunakan 2 lokasi/area. Biasanya respon $\mathrm{S}$ dikombinasi $\mathrm{D}$ atau $\mathrm{W}$, dsb., misal :

Kartu I : seperti di atas

c) Subyek menggunakan area tertentu untuk main respon, tetapi didalam inquiry menambah area lain untuk melengkapi, agar konsepnya logis, misal :

Kartu VI : dua ekor binatang memanjat sesuatu (area samping) $\rightarrow$ D. Inquiry : mereka memanjat gunung $\rightarrow \mathrm{W}$, 
sehingga skor-nya menjadi :

\section{$\mathrm{D} \rightarrow \mathrm{W}$}

$\underline{\text { catatan }}:$ tanda $(\rightarrow)$ menunjukkan kecenderungan / arah jawaban.

d) Subyek menggunakan 2 atau lebih jawaban independent menjadi satu jawaban, misal :

Kartu VIII : dua beruang memanjat sesuatu dan yang lain seperti bendera yang bersilangan. Inquiry : Secara keselu-ruhan tampak seperti emblem
D
D $\} W$

Kartu X : ini tampak seperti kepiting, sedang ini karang. Ini ganggang laut secara keseluruhan mengingatkan saja pada pemandangan laut.
$\left.\begin{array}{l}D \\ D \\ D\end{array}\right\} W$ 

Catatan : tanda\} menunjukan respon- respon independent dija-dikan satu.

\section{Skor-skor Lokasi Usual Detail (D,d)}

Beberapa skor lokasi Usual Detail (D,d) diberikan berdasar penggunaan area bercak di peta lokasi seperti di bawah ini

\section{KARTU I}

a. Skor D ( lokasi detail besar yang umum digunakan )

1. Bagian tengah keseluruhan dengan atau tanpa warna abu-abu yang lebih muda

2. Bagian samping keseluruhan

3. Bagian tengah bawah tanpa warna abu-abu yang lebih muda

4. Bagian tengah bawah keseluruhan

5. Bagian samping atas

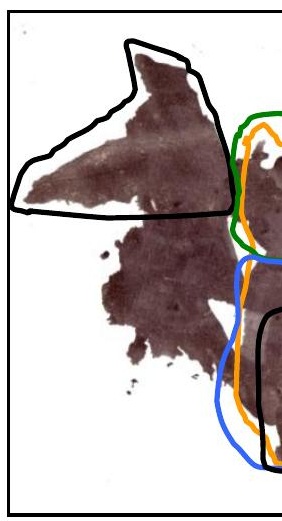

6. Bagian atas tengah 
b. Skor d ( lokasi detil kecil yang umum digunakan )

1. Bagian yang menonjol di atas agak di luar

2. Bagian samping agak ke bawah

3. Bagian atas agak ke dalam, seperti ujung cakar

4. Bagian yang menonjol paling atas

5. Bagian yang menonjol di bagian paling dalam di atas

6. Bagian yang menonjol di bagian paling bawah

7. Bagian seperti tombol kecil yang menonjol di bagian samping agak ke bawah.

Respon $\mathbf{P}$ ( populer) pada kartu I :

W atau : semua mahluk dengan badan pada bagian.

D tengah, dan sayapsayapnya di kedua sisi

\section{KARTU II}

a. Skor D 
1. Bagian merah di bawah, dengan atau tanpa campuran merah hitam

2. Bagian merah di atas

3. Bagian hitam di samping keseluruhan

4. Bagian hitam yang di atas

b. Skor d

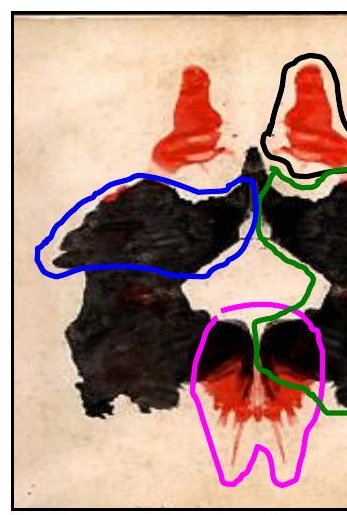

1. Bagian atas tengah, dengan atau tanpa warna abu-abu luarnya

2. Bagian bawah terluar

3. Bagian bawah yang beebelahan dengan no. 2

4. Bagian samping atas yang menonjol

\section{Respon P}

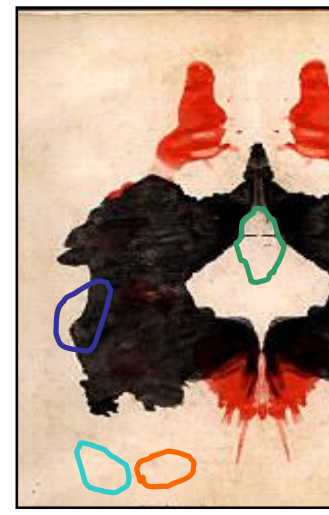

1. W : daerah berwarna hitam, dengan atau tanpa bagian tengah atas d

2. D : daerah berwarna hitam sebagai segala bentuk binatang atau bagian dari binatang seperti : anjing, beruang, kelinci, kerbau, jenis-jenis badak. 


\section{KARTU III}

\section{a. Skor D}

1. Bagian merah dalam

2. Bagian merah luar dengan atau tanpa bagian yang seperti ekor

3. Bagian tengah bawah keseluruhan

4. Bagain tengah bawah berwarna hitam

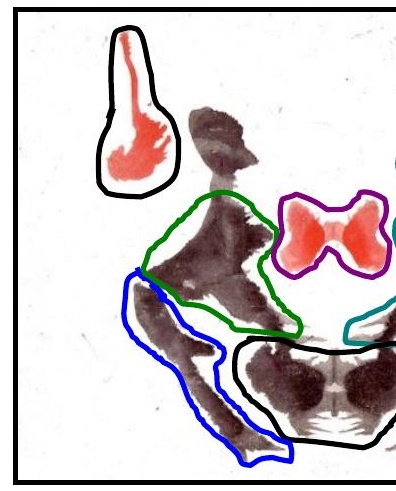

5. Bagian samping bawah berwarna hitam

6. Bagian samping atas berwarna hitam (kepala dan bagian atas tubuh figur yang umum)

7. Bagian samping tengah warna hitam

8. Bagian samping keseluruhan

9. Bagian tengah bawah warna abu-abu muda

b. Skor d

1. Bagian bawah samping warna hitam, kadang- kadang dengan bagian bawah sebagai bagian dari kaki.

2. Bagian atas samping warna 
hitam

3. Bagian tengah samping warna

hitam dan menonjol, biasanya posisi

terbalik.

Respon P :

\section{Seluruh area warna hitam :}

2 figur manusia dalam posisi

membungkuk. Kaki-kaki tampak pada area D dan figur dalam keadaan bergerak. Bisa juga dilihat sebagai binatang berpakaian dengan bagian kaki adalah bagian yang biasa dilihat sebagai tangan, atau binatang yang tidak berpakaian dengan sepasang kaki yang sebagian besar dinilai sebagai $\mathrm{P}$ additional.

2. Area D didalam : dilihat seperti “ dasi kupu-kupu ", " pita rambut " atau " kupu-kupu ". Boleh dilihat karena bentuknya atau bentuk digabung dengan warna.

\section{KARTU IV}

a. Skor D

1. Bagian bawah tengah

2. Bagian bawah samping warna hitam dan abu-abu, kadang-kadang dengan bagian atas samping. 
3. Bagian bawah samping warna abu-abu terang

4. Bagian vertikal tengah warna gelap, kadang kadang dengan area $\mathrm{d}$ nomer 2 .

5. Bagian bawah samping warna hitam.

\section{b. Skor d}

1. Bagian atas samping diteruskan dengan atau tanpa bagian kecil di dekatnya.

2. Bagian paling atas, kadangkadang dengan bagian di dekat nya yang agak gelap.

3. Bagian paling luar bawah yang menjorok.

4. Bagian paling bawah tengah.

\section{KARTU V}

a. Skor D

1. Bagian samping dengan atau tanpa bagian berwarna abu-abu terang yang menjorok.

2. Bagian vertikal tengah keseluruhan .

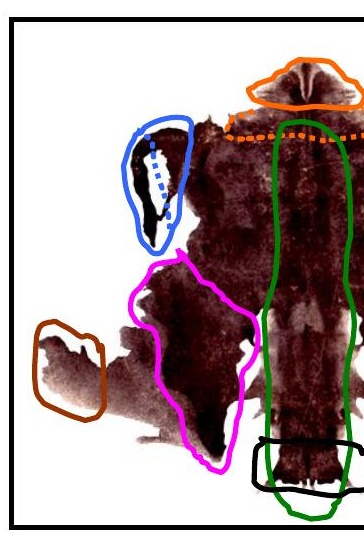

$$
110 \text { |P a g e }
$$




\section{b. Skor d}

1. Bagian bawah tengah.

2. Bagian samping menjorok, kadang-kadang dengan bagian tipis menjorok di dekatnya.

3. Bagian atas tengah dengan atau tanpa tonjolan di atasnya.

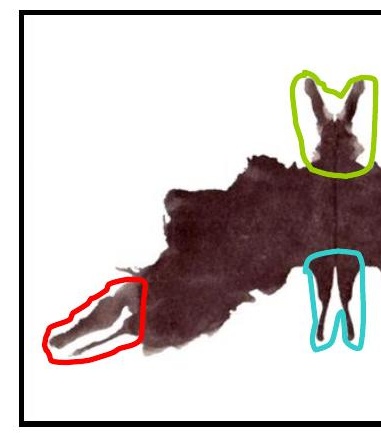

4. Bagian pinggir paling atas.

\section{Respon P :}

1. W atau W : setiap mahluk bersayap dengan bagian tengah area D adalah tubuhnya dan sayap-sayap di bagian samping. Konsep yang sama bila posisi kartu terbalik.

\section{$\underline{\text { KARTU VI }}$}

\section{a. Skor D}

1. Bagian bawah keseluruhan atau separo bagian bawah.

2. Bagian atas keseluruhan, kadangkadang dengan bagian paling atas dari detil bawah yang berwarna abu-abu muda.

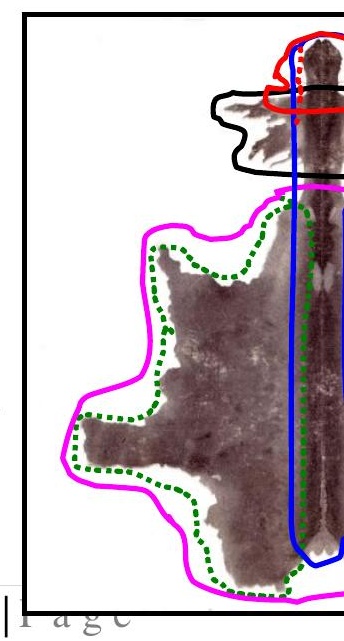


3. Bagian atas berwarna hitam dari kolom tengah saja, kadang-kadang tanpa bagian luar bershading tipis.

4. Bagian vertikal tengah gelap keseluruhan.

5. Hanya bagian yang lebih terang di bagian atas.

b. Skor d

1. Bagian paling atas dengan atau tanpa "janggut".

2. Bagian samping yang menjorok.

3. Dua bagian oval didalam yang berwarna abu-abu muda.

4. Bagian dalam bawah.

\section{Respon P :}

1. Dengan atau tanpa D di atas : kulit binatang, dan harus menggunakan unsur shading untuk kesan berbulu atau mewakili bagian dalam dari kulit.

\section{$\underline{\text { KARTU VII }}$}

\section{a. Skor D}

1. Bagian dasar keseluruhan atau 
separonya.

2. Bagian tengah.

3. Bagian puncak dengan atau tanpa bagian menonjol di atas.

4. Dua pertiga bagian atas.

b. Skor d

1. Bagian dasar tengah berwarna gelap.

2. Bagian menonjol paling atas.

3. Bagian menonjol berwarna abuabu terang dari area paling atas.
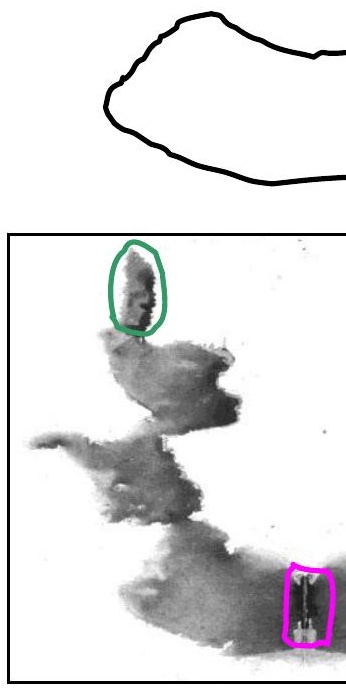

\section{KARTU VIII}

\section{a. Skor D}

1. Bagian samping berwarna merah muda

2. Bagian dasar berwarna merah muda dan oranye.

3. Bagian puncak berwarna abu-abu dengan atau tanpa garis tengah, kadang-kadang dengan figur seperti iga dan/atau bagian berwarna biru.

4. Bagian tengah berwarna biru. 
5. Figur seperti iga di bagian atas tengah

6. Bagian dasar berwarna merah muda

7. Bagian dasar berwarna oranye.

\section{b. Skor d}

1. Bagian sambungan di samping bawah berwana oranye.

\section{Respon $\mathbf{P}$}

1. Bagian D samping : semua jenis binatang dalam keadaan bergerak. Jika tidak dilihat dalam keadaan bergerak atau jika dilihat sebagai burung atau ikan diberi skor cenderung P ( $\mathrm{P})$. Jika unsur warna diguna-kan diberi skor additional.

\section{$\underline{\text { KARTU IX }}$}

\section{a. Skor D}

1. Bagian berwarna hijau

2. Bagian berwarna oranye

3. Bagian dalam kecil pada per-

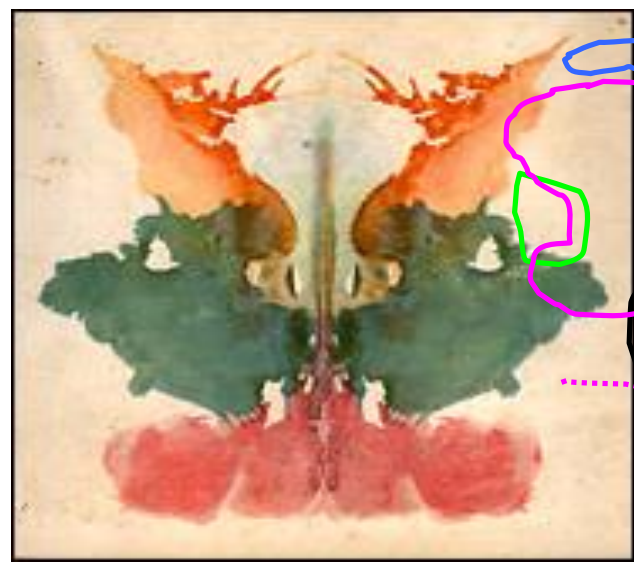

batasan berwarna hijau dan oranye (kadang-

kadang dilihat sebagai kepala tikus). 
4. Bagian samping berwarna merah muda.

5. Bagian berwarna merah muda keseluruhan ditambah daerah ver-tikal tengah.

6. Bagian berwarna merah muda

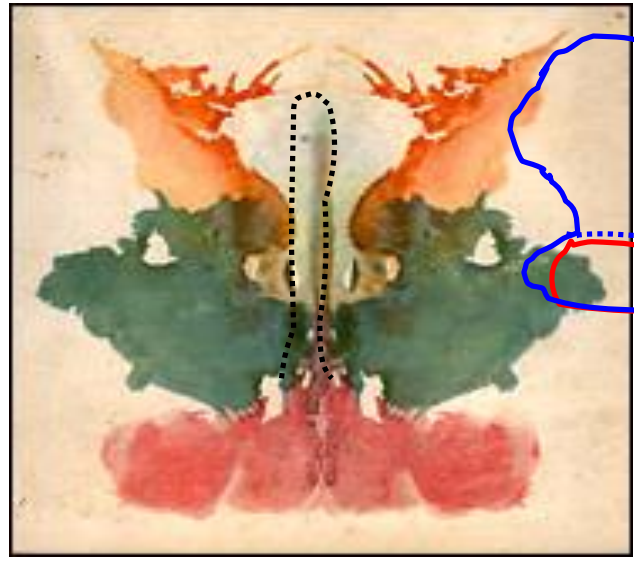
keseluruhan atau separonya.

7. Bagian tengah di antara warna hijau.

8. Bagian tengah berwarna abu-abu den an atau tanpa area D nomer 7 di atas.

9. Bagian dalam berwarna merah muda, kadang-kadang dengan area vertikal tengah.

10. Bagian tengah berwarna abuabu dan area putih dengan atau tanpa area D nomer 7 di atas ( D,S ).

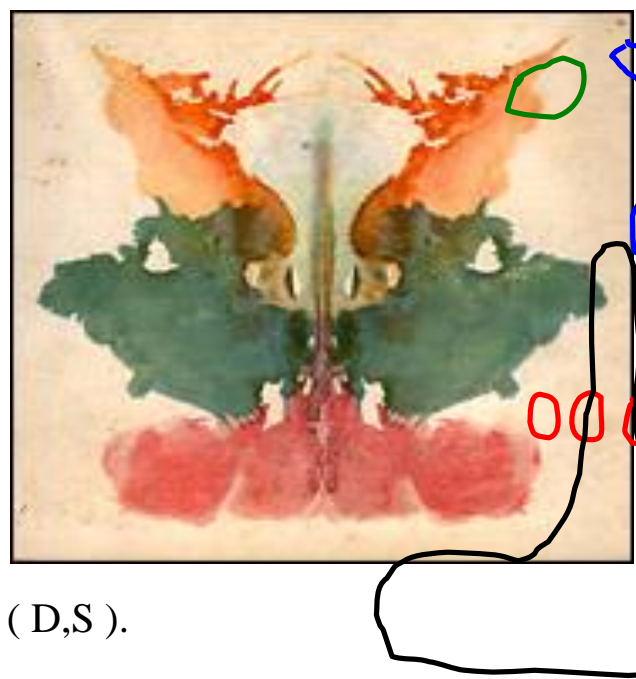




\section{b. Skor d}

1. Semua atau sebagian besar daerah menonjol di bagian dalam atas berwarna oranye.

2. Bagian seperti mata di tengah termasuk yang berwarna hijau dan celah putih.

3. Bagian seperti busur berwarna oranye terang/muda di area puncak tengah.

\section{$\underline{\text { KARTU X }}$}

\section{a. Skor D}

1. Bagian luar berwarna biru, kadang -kadang dengan bagian atasnya yang berwarna hijau.

2. Bagian bawah berwarna hijau gelap, kadang kadang dengan bagian yang lebih terang.

3. Bagian paling atas berwarna abuabu keseluruhan.

4. Bagian paling atas berwarna abuabu tanpa tiang berwarna abu-abu di dalam.

5. Bagian bawah berwarna hijau ke-

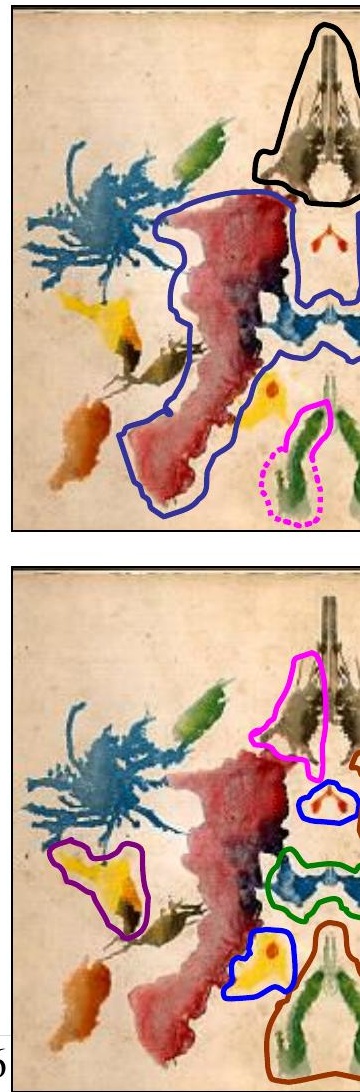


seluruhan.

6. Figur bagian luar berwarna coklat abu-abu.

7. Bagian atas area D nomer 5 berwarna hijau terang/muda.

8. Bagian dalam berwarna biru.

9. Bagian berwarna merah muda.

10. Bagian dalam berwarna kuning.

11. Bagian luar berwarna oranye.

12. Bagian dalam berwarna oranye.

13. Bagian atas berwarna hijau.

14. Tiang berwarna abu-abu di bagian atas tanpa bagian berwarna abu-abu di sampingnya.

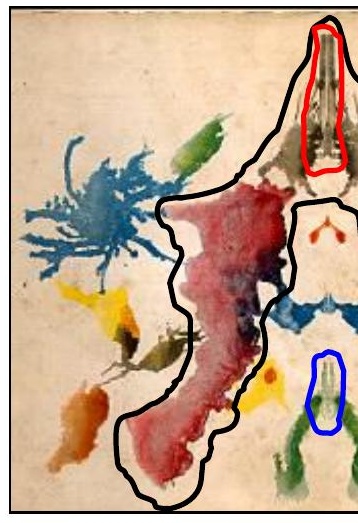

15. Bagian luar berwarna kuning.

16. Bagian berwarna merah muda dengan bagian atas berwarna abu-abu keseluruhan, posisi kartu terbalik.

17. Bagian berwarna merah muda dengan bagian

18. berwarna biru di dalam.

\section{Respon $\mathbf{P}$ :}

1. Area D di luar berwarna biru : semua binatang berkaki banyak, seperti laba-laba, 
kepiting, atau gurita. Bila menggunakan unsur warna diberi skor $\mathrm{O}$ (original) additional.

2. Area D nomer 2 di bawah berwarna hijau : semua binatang bertubuh panjang dan berwarna hijau, seperti ulat, ular kebun, atau cacing tembakau. Unsur warna harus digunakan, kalau tidak maka hanya diberi skor P additional.

\section{Area D nomer 7 yang berwarna hijau} terang : seperti kepala binatang dengan telinga panjang atau bertanduk, seperti kelinci, keledai, atau kambing. Tambahan area lain (seperti : area D nomer 2 atau $\mathrm{S}$ ) mendapat tambahan skor $\mathrm{O}$ additional.

\section{B. Determinant}

Skoring terhadap kualitas jawaban yang diberikan subyek. Apa alasan subyek melihat kesan / gambar sedemikian rupa. Secara umum ada 4 (empat) alasan, yaitu :

1. Form

2. Movement

3. Shading

4. Color 
Keempat kategori tersebut secara lebih detil bisa dijelaskan sebagai berikut :

\section{Form Response ( F )}

Bila subyek menggunakan alasan melihat bentuk saja pada konsep / respon yang dibuat. F ini, selain dipakai untuk respon /konsep yang jelas, dipakai pula untuk respon-respon yang kabur, abstrak, atau tidak jelas, misal :

Kartu III : seperti kupu (area merah tengah), karena bentuknya seperti kupu

Kartu V : $\quad$ seperti kelelawar (W), karena seperti kupu bentuknya.

\section{Movement Response}

Konsep yang dibuat subyek dalam bentuk melakukan gerakan / aksi, menunjukan ekspresi atau hidup, juga menunjukan sikap.

Macam respon movement / gerakan :

\section{a) M (Human Movement )}

Bila subyek memberikan respon berkenaan dengan menusia dalam gerakan atau menunjukan ekspresi. Juga diberikan pada 
karikatur, binatang yang dimanusiakan, misal

Kartu I : seperti 2 orang tukang sihir sedang menarikan tarian setan.

Kartu II : sepasang pelawak saling menepuk tangan.

KartuV : dua wanita sedang tiduran dengan rambut panjangnya menutupi punggungnya (area samping D)

b) FM (Animal Movement)

Bila subyek merespon hewan yang bergerak, termasuk karikatur, binatang yang dilatih manusia, seperti : gorila yang dilatih menari, misal :

Kartu I : kelelawar terbang

Kartu VI : seperti burung bertengger disesuatu (area paling atas)

Kartu VIII : kodok "ngorek" kepalanya muncul di atas air (area pink bawah)

c) m ( Inanimate movement ) 
Untuk benda-benda dalam keadaan gerak (bukan manusia dan bukan binatang). Skor ini terdiri dari :

1. Fm : benda yang punya bentuk jelas dan sedang bergerak, Misal :

Kartu II : seperti gasing sedang berputar kencang (white space)

2. m : gerakan tanpa bentuk sama sekali, misal :

$$
\begin{gathered}
\text { Kartu VII : sesuatu yang tidak } \\
\text { terintegrasi seperti : } \\
\text { kembang api , letusan } \\
\text { gunung berapi, dsb. }
\end{gathered}
$$

3. $\mathbf{m F}$ : bentuknya setengah jelas dalam gerakan, misal :

Kartu $X$ : daun-daun berguguran (W) perlahan-lahan ter-kena angin.

Kartu IX : awan sedang bergerak, air sungai mengalir.

3. Shading Response 
Penggunaan faktor shading / bayangan lebih gelap atau terang dari area-area berwarna yang berbeda-beda. Ada 3 alasan respon menggunakan unsur shading yang terungkap :

a) Surface atau Texture Response yang meliputi :

1. Fc : Obyek yang dilihat punya bentuk jelas dengan menggunakan faktor permukaan / surface atau tekstur. Bentuk obyek tidak jelas tetapi punya teksture yang jelas terdiferensiasi, misal :

Kartu I : Seorang wanita berpakaian transparan, ia orang seorang penari. Tampak pinggul depan lewat roknya (area bawah)

$\rightarrow$ Faktor transparan menunjukan penekanan pada penggunaan kualitas permukaan.

Kartu IV : Kepala udang yang berkulit tipis. Tampak bagian 
dalam kepala udang (area bawah tengah, D)

$\rightarrow$ Bayangan bagian dalam kepala udang seolah-olah terlihat jelas.

2. cF : untuk obyek yang punya bentuk kurang jelas dan efek permukaan tekstur, juga tidak terlalu terdifferensiasi.

Misal :

Kartu VI : Secara keseluruhan seperti batu karang, tampak ada bayangan sehingga terkesan kasar dan keras.

3. c : obyeknya tanpa bentuk yang jelas dan shading yang digunakan tidak terdifferensiasi (hanya menekankan shadingnya), misal :

Kartu IV : Sesuatu yang kalau disentuh terasa lembut dan berpori. 
$\rightarrow$ Tidak berbentuk, shading tidak terdifferensiasi.

b. Vista ( response kedalaman / respon 3 dimensi )

Penggunaan faktor persepsi kedalaman / tiga dimensi.

Ada 3 macam : FK, KF dan $\mathrm{K}$

1. FK : adanya faktor kedalaman dengan bentuk yang jelas.

$\rightarrow$ shading-nya terkesan seperti ada jarak antara 2 benda atau lebih. Shading abu-abu yang lebih terang dan lebih gelap menunjukkan adanya jarak yang berbeda.

Misal :

Kartu V : Seperti suatu dataran dengan danau di sekitarnya bila dilihat dari atas tampak pasir-pasir (pantai pasir) di tepinya. 
$\rightarrow$ Pemandangan udara yang terdiffensiasi ini me-ngarah ke FK.

2. KF : obyeknya punya bentuk yang setengah jelas dan shading yang digunakan mengambarkan sesuatu yang terorga-nisir, kabur seperti : asap, dsb., misal :

Kartu II : Tampak asap berbentuk spiral yang berasal dari kebakaran. Asap tampak tebal

$\rightarrow$ spiral mengarah ke KF

Kartu VII : Seperti awan di langit

$\rightarrow$ tampak tidak ada garis-garis yang jelas dan kelihatan tipis, terang dan ada ke-dalaman.

3. K : hanya shading yang tidak terorganisir yang ditekankan dan tidak ada bentuknya, misal : 
Kartu V : Terkesan seperti suatu ruangan gelap, terasa ada faktor kegelapan

$\rightarrow$ kegelapan mengarah ke

K.

Kartu IX : Kabut, mungkin kabut di pagi yang cerah di pedesaan

\section{c. Nuansa}

Efek 3 dimensi yang diproyeksikan dalam gambar 2 dimensi. Ada 3 macam skor nuansa

1. Fk : punya bentuk yang jelas dengan penggunaan shading yang tidak jelas / kabur, misal :

Kartu IV : Gambar sinar $\mathrm{X}$ yang menunjukan bintik-bintik pada paru-paru.

$\rightarrow$ Bintik-bintik pada paru menunjukkan adanya bentuk yang jelas.

2. $\mathbf{k F}$ : bentuk obyeknya setengah jelas dan shading-nya (tetap) kabur, misal : 
Kartu I : Beberapa bagian seperti bagianbagian pada peta.

Inquiry : ini lautan seperti yang ada pada buku geografi

$\rightarrow$ Jika tidak dijelaskannya area / daerah apa secara pasti (tidak ada nama tertentu) sehingga bentuk obyeknya tampak tidak begitu jelas, maka cukup diskor KF.

3. k : hanya shading tanpa bentuk yang jelas, misal :

Kartu IV : Tampak seperti sinar X karena ada bintik-bintik pada shading-nya (area : di ).

\section{Color Response}

Skor yang diberikan bila konsep yang ditunjukkan subyek meng-gunakan kualitas warna sebagai alasannya. Ada 2 macam color response:

a) Chromatic color / C : 
Menggunakan warna-warna , seperti : merah, hijau, biru, dsb. Variasi penggunaannya :

\section{FC}

Bila konsep jawaban subyek punya sifat :

1. Obyeknya punya bentuk jelas ; 2 . Menggunakan kualitas warna ; 3. Warna yang digunakan sesuai dengan warna asli, misal :

Kartu IX : Baju pesta berwarna hijau yang indah.

Kartu X : Saya melihat banyak bunga, yang kuning gladiol.

Ada 3 macam variasi skor FC :

\section{a. F↔C (Force FC)}

Bentuk respon / obyeknya jelas, tapi warna yang digunakan adalah warna yang dipaksakan/bukan warna yang sebenar-nya, misal :

Kartu II : Ada dua anjing laut

merah

Kartu VII : Tikus merah 


\section{b. F/C (Arbitrary FC)}

Diberikan pada respon-respon dimana warna hanya dipakai untuk menerangkan bagian-bagian yang direspon dengan bentuk yang jelas. Biasanya pada respon yang menyangkut :

peta-peta berwarna atau peta kedokteran / medis, misal :

Kartu VIII: Seperti kerangka tubuh, ada dada, perut, tulang rusuk dan pembuluh darah di paru (area W kecuali area tikus)

Inquiry : Tubuh sebenarnya tidak demikian, tapi warnawarnanya seperti yang sering ada di buku-buku anatomi.

$\rightarrow$ Organ-organ tubuh jelas disebutkan jadi $\mathrm{F} / \mathrm{C}$ 
Kartu $\mathrm{X}$ : Yang di tengah tampak seperti gambar peta yang menggambarkan dua garis pantai dari dua negara dengan sebuah jembatan di antara kedua negara tersebut $($ area $=$ merah tengah)

Inquiry : seperti pantai di Peru dan Chili, warnanya ini yang digunakan untuk membedakan dari bagian lain.

$\rightarrow$ tampak penggunaan warna orbitrary.

\section{c. FCsym (Symbolic Color)}

Bila responnya menggunakan warna sebagai simbol dari obyek yang punya bentuk jelas, misal : 
Kartu II : Seperti dua orang yang berselisih / berkelahi saling menjulurkan lidah. Inquiry : lidah dan warna merah merupakan simbol kemarahan

$\rightarrow$ Score : M, FCsym

Kartu X : Seperti dua wanita dalam pakaian / baju tidur berwarna pink. Inquiry : warna pink merupa-kan simbol seorang wanita.

\section{2. $\mathbf{C F}$}

Bila obyek setengah jelas dan menggunakan warna-warna (variasivariasinya sama dengan FC hanya di sini dengan setengah jelas), misal :

Kartu X : Suatu padang rumput $($ area $=$ $\mathrm{W})$

Inquiry : karena tampak warna-warni.

$\rightarrow$ tidak jelas tanaman apa saja, jadi diskor CF. 
Kartu IX : Suatu desain dengan warnawarna pastel.

$$
\begin{aligned}
& \text { Inquiry : tampak segar dan } \\
& \text { merah. Suatu ruangan yang } \\
& \text { berkesan segar }
\end{aligned}
$$

Variasi-variasi lain yang termasuk kategori ini :

a. $\mathbf{C} \leftrightarrow \mathbf{F}$, misal :

Kartu VIII : Batu-batuan berwarna, terkesan keras, lem-but dan bergelombang. Inquiry : batu-batuan yang tampak lembut dan menarik, berwarna pink pada kartu ini. Tidak pernah ada batubatuan yang seperti ini.

b. $\mathbf{C} / \mathbf{F}$, misal :

Kartu VIII : Seperti keadaan dalam tubuh (area W).

Inquiry : saya pernah lihat seperti ini, seperti 
perut atau yang ada di dalam lainnya.

$\rightarrow$ Bagian-bagian tubuh kurang terinci dan respon lebih ditentukan warna.

c. CFsym, misal :

Kartu IX : Api neraka, belerang dan api. Merah di bawah adalah api neraka, mengesankan sesuatu yang mengancam.

$\rightarrow$ Respon api cenderung $\mathrm{CF}$, tetapi ada kesan simbol menyebabkan respon ini lebih sesuai diskor CFsym.

3. C : Bila respon menekankan warna tanpa ada bentuk. masih dibagi dalam 4 macam :

a. C (Crude Color) 
Bila warna asli /alami dari obyek digunakan, misal :

Kartu II : Bagian merah di atas adalah darah.

Kartu III : Di sini lebih banyak darah, di sini, di situ (area merah atas, bawah).

\section{b. Cn (Color naning)}

Bila warna yang dipakai hanya menerangkan warna-warna yang ada dalam kartu. Syarat pengkategorian $\mathrm{Cn}$ :

1. Subyek merasa satu-satunya cara menanggapi kartu tersebut dengan menyebutkan warna-warnanya.

2. Apa yang dikatakan (warna-warna tersebut) itulah respon / jawaban.

3. Tidak bisa memberi penjelasan

lebih lanjut.

Misal :

Kartu VIII : Ada banyak warnawarna terang / cerah 
disini, merah, biru, pink, orange.

Inquiry : Ini merah, pink, biru, orange saya hanya melihat warna saja.

Kartu X : Banyak sekali warnawarna pink, biru, kuning dan hijau.

Inquiry : Hanya warnawarna pink, hijau biru, kuning emas coklat, abu-abu, yang saya pikir dan lihat.

Jadi, ada kecenderungan hanya menyebut warna-warna.

\section{c. Cdes (Color Description)}

Bila subyek memberi gambaran/penjelasan tentang terjadinya warna-warna di kartu. Syarat skor Cdes : a. Subyek menganggap uraian/penjelasan tersebut adalah 
responnya ; b. Uraian tersebut bukan merupakan perluasan/rincian dari FC atau CF.

Misal :

Kartu IX : Warna hijau di tengah bertemu warna orange di atas dan bercampur dengan warna pink di bawah, seperti cat air.

Inquiry : Warna-warna tersebut bercampur dan kabur di tengah, tapi membentang dan ditipiskan jadi putih.

\section{d. Csym (Color Symbolism)}

Bila subyek menggunakan warna untuk ide-ide yang abstrak dan melambangkan simbol tertentu, misal :

Kartu X : Gambar tentang kegembiraan. Warna musim semi dan ulang tahun. 
Inquiry : Mula-mula warna abu-abu yang melambangkan tahun lalu yang kemudian dan penuh pengharapan.

Kartu X : Ada warna hijau di bawah, semacam / simbol dari rasa cemburu / iri.

b) Achromatic Color / C'

Menggunakan warna, seperti : abu-abu, hitam atau putih. Skor ini terdiri dari 3 macam :

1. FC' : Bila respon menggunakan warnawarna akromatis de-ngan bentuk yang jelas, misal :

Kartu I : Kupu-kupu hitam-putih (W)

Kartu VII : Mainan anjing berwarna abu-abu. 
2. C'F : Bentuk respon / obyek setengah jelas dengan kealitas warna akromatis, misal :

Kartu I : Seperti awan petir.

Inquiry : Begitu hitam, seperti petir / guntur.

3. C' : Respon menggunakan warna achromatis saja, tanpa ben tuk sama sekali, misal :

Kartu IV : Seperti angin topan.

Inquiry : Seperti efek umum dari angin topan karena terkesan hitam dan abu-abu tua $\rightarrow$ tidak ada bentuk.

\section{Content}

Skor content merupakan skor yang diberikan untuk isi jawaban testee.

Dalam proses pemberian skornya, isi jawaban yang diutarakan testee dimasukan kedalam kategorikategori mana yang mirip, dan itu menjadi skor kontennya. Ada kemungkinan jawaban testee tidak termasuk dalam salah satu kategori yang tersedia, 
maka konsep/jawaban tersebut dapat diberi skor sesuai dengan isi jawaban itu sendiri, misal :

\begin{tabular}{|l|l|}
\hline konsep/jawaban & \multicolumn{1}{|c|}{ skor konten } \\
\hline - Kematian & - Death \\
- Letusan & - Exp. (explotion) \\
- Api & - Fire \\
- dst. & - dst. \\
\hline
\end{tabular}

Kategori-kategori skor konten yang ada :

$\mathbf{H}$ (Human figure) : Isi jawaban berkenaan dengan manusia.

Misal :

Kartu I : Di tengah ini seorang wanita yang berdiri dengan mengangkat tangan dan kakinya bersamaan.

Inquiry: dilihat dari belakang dengan tangan di atas.

Kartu V : Seorang wanita dengan kostum pesta seperti serangga.

Inquiry : baju beludru halus dengan jarijarinya tampak.

(H) : Respon-respon yang mengandung hal-hal yang dimanusiakan, seperti : karikatur, 
boneka atau figur-figur seperti hantu, raksasa, tukang sihir.

Misal :

Kartu II : Seperti patung yang sedang mengangkat "toast".

Kartu III : Dua boneka kecil dengan suatu alat musik.

Hd : Isi jawaban berkenaan dengan bagian tubuh manusia, tetapi bukan anatominya.

Misal :

Kartu IV : Kaki yang terangkat.

Inquiry: seperti gerakan tarian.

Kartu V : Kepala manusia

(Hd) : Bagian dari hal-hal yang dimanusiakan.

Misal :

Kartu I : Ini adalah jari-jari setan, kepala raksasa, tangan-tangan boneka.

AH : Jawaban-jawaban seperti : setengah manusia dan setengah hewan.

Misal :

Kartu III : - Ikan duyung 
- Dua orang sedang membungkuk pada sesuatu. Sepertinya setengah manusia dan setengah hewan.

Inquiry : Bagian atas seperti orang tetapi bagian bawah lebih mirip bagian tubuh hewan. )

Hobj : Obyek-obyek yang erat hubungannya dengan manusia, seperti gigi palsu.

At : Bagian dari tubuh manusia yang berkaitan dengan anatomi (kecuali organ-organ sex)

Misal :

Kartu VII : Seperti pembedahan bagian-bagian usus.

Kartu VIII : Seperti tulang iga. Tepatnya seperti sinar $\mathrm{X}$ dari tulang iga.

Sex : Diberikan pada organ seks, sexual activity bagian anatomi yang berhubungan dengan sekx.

Misal :

Kartu I : Penis (D tengah)

Kartu IV : Seperti payudara dan ini puting susunya.

A : Figur hewan (jawabannya mengenai hewan) 
Misal :

Kartu II : Beruang kembar

Kartu VII : Tikus yang sedang memanjat.

(A) : Respon-respon berkenaan dengan binatangbinatang mitos, seperti : monster yang berciri hewan, karikatur hewan atau yang menyerupai hewan.

Misal :

Kartu I : Sejenis hewan mitos yang bersayap.

Kartu X : Ulat hijau yang unik / aneh, punya

kesan tertentu.

Ad : Jawabannya tentang bagian-bagian tubuh

hewan.

Misal :

Kartu VI : Sungut kucing.

Kartu VII : kepala biri-biri.

(Ad) : Bagian-bagian tubuh hewan yang tidak ada dalam kenyataan atau binatang yang seperti manusia.

Misal :

Kartu IV : Kepala naga. Naga yang memakai mahkota. 
Aobj : Tentang obyek-obyek yang ada hubungannya dengan hewan. Biasanya berupa dekorasi dan hiasan.

Misal :

Kartu VI : Kulit hewan yang dipaku didinding, seperti kulit racoon

Kartu V : Tulang garpu dari kalkun

A.At : Konsep tentang anatomi hewan, termasuk didalamnya : sinar $\mathrm{X}$ dari hewan, dsb.

Misal :

Kartu I : Seperti tulang hewan (W,S).

Inquiry : Seperti tulang dalam buku

biologi.

Food : Untuk respon-respon berupa bagian binatang, buah-buahan atau sayuran yang dapat dimakan.

Misal :

Kartu VI : Sekerat roti berjamur.

Kartu IX : “Sea-Food” seperti yang ada direstoran.

N : Konsep-konsep tentang alam. Termasuk didalamnya pemandangan alam, matahari, sungai dan danau-danau.

Misal : 
Kartu VI : Celah di es. Celah yang dalam dengan air didasarnya.

Kartu X : Pemandangan taman, dengan menara diujungnya.

Geo : Konsep yang berkenaan dengan geografi, termasuk : peta, pulau, teluk, dsb ; tetapi tidak ada hubungannya dengan pemandangan.

Misal :

Kartu VIII : Bagian paling atas seperti puncak gunung.

P1 : Plent, semma jawaban yang mengenai tumbuhan dan bagian tumbuhan.

Misal :

Kartu X : Seperti daun musim semi (area kuning bawah).

Bot : Botani, tumbuhan atat bagian tmmbuhan yang tidak hidup. Gambar tumbuhan.

Misal :

Kartu X : Gambar ini seperti peta botani / sesuatu yang berwarna.

Obj : Obyek-obyek buatan manusia ; selain patung $[(\mathrm{H})]$ atau $[(\mathrm{A})]$.

Misal : 
Kartu IV : Sepatu boot yang kuno.

Kartu IX : Seperti jam pasir.

Arch : Konsep-konsep tentang arsitektur

Misal :

Kartu X : Seperti menara eiffel (area coklat).

Art : Konsep-konsep seperti disain, lukisan yang tidak ada tema khususnya.

Catatan : Lukisan manusia $\rightarrow(\mathrm{H})$;

Lukisan pemandangan $\rightarrow \mathrm{N}$

Misal :

Kartu IX : Ini mungkin coretan cat air.

Abs : Abstrak, konsep yang tidak ada tema

tertentu / khusus.

Misal :

Kartu VII : Yang saya rasakan disini seperti sesuatu yang tidak menyatu, sesuatu yang terpisah.

Kartu VIII : Sesuatu yang tertutup dan terlindungi (area atas). 


\section{D. $\mathbf{P}$ - $\mathbf{0}$}

Skor untuk menentukan apakah jawaban / konsep subyek tergolong $\mathrm{P}$ (populer) atau $\mathrm{O}$ (original).

\section{a. P (Populer response)}

Respon-respon yang seringkali muncul pada area-area percikan tertentu. Jika konsep/respon subyek tergolong konsep yang memenuhi kategori seringkali muncul, maka konsep/respon yang dikemukakan subyek diberi skor $P$.

Ada 10 jenis respon yang bisa diberi skor $\mathrm{P}$ :

\section{Kartu I}

Dengan lokasi $\mathrm{W}$, atau $\mathrm{W} \backslash$. Berupa binatang atau mahluk ber-sayap dengan tubuh di area D tengah dan sayap di kedua sisi mahluk tersebut. Bisa dalam keadaan diam atau bergerak / action, misal :

- Seekor kupu-kupu yang mengepakkan sayapnya.

- Seekor kelelawar yang sangat besar.

\section{Kartu II}

Dengan area hitam, baik dalam $\mathrm{W}$ atau $\mathrm{D}$. Biasanya muncul respon berupa = anjing, beruang, kelinci atau sapi jantan dengan atau 146 |P a g e 
tanpa area tengah kecil dan bagian tubuhnya, kadang-kadang kualitas tekstur kulit bisa muncul, misal :

- Dua beruang kecil dengan masing-masing hidungnya beradu

- Seperti kepala anjing pendek.

\section{Kartu III}

Dengan area semua bagian hitam. Muncul respon, seperti dua orang manusia, atau hewan yang berpakaian seperti manusia. Dengan kaki diarea bawah. Figur harus dalam keadaan bergerak, misal :

- Dua orang laki-laki sedang memegang suatu paket dan me-letakkannya ke tanah.

- Dua kangguru yangberpakaian seperti pelayan membawa baki.

\section{Kartu III}

Dengan area / lokasi merah tengah. Respon yang sering muncul seperti $=$ dasi kupu-kupu, pita rambut atau kupu-kupu. Warna bisa dimunculkan atau tidak, misal : 
- Kupu-kupu ditengah dengan sayap disamping. Ini tubuhnya

- Seperti dasi kupu-kupu besar ditengah.

\section{Kartu V}

Dengan area W. Berupa mahluk bersayap dengan tubuh ditengah (D) dan sayap di kedua sisi, misal :

- Seekor kelelawar.

- Seekor serangga yang terbang kearah kita.

- Tampak seperti kupu-kupu yang sedang terbang.

6. Kartu VI

Dengan area / lokasi W, atau semua bercak tanpa area teratas (W). Berupa kulit binatang, dengan menggunakan shading untuk menggambarkan permukaan kulitnya, misal :

- Selembar kulit binatang

- Kulit dari binatang yang dipaku di dinding seperti kulit raccon.

\section{Kartu VIII}

Dengan lokasi area warna pink. Responnya binatang berkaki empat, misal : 
- Seperti binatang berang-berang, sedang memanjat.

8. Kartu X

Areanya biru samping. Respon yang sering adalah binatang berkaki banyak, seperti : laba-laba, ubur-ubur dan kepiting, misal :

- Kepiting.

9. Kartu X

Area / lokasi hijau tengah bawah, tanpa area hijau muda-nya.

Responnya berupa binatang berwarna kehijauan dan bentuknya panjang, seperti $=$ ulat, ulat kebun. Kualitas warna harus tersertai, misal :

- Ulat tembakau . Inquiry : warnannya seperti ulat tembakau.

- Sepasang ulat di daun. Inquiry : warna dan bentuknya seperti ulat yang sedang makan daun.

10. Kartu X

Lokasi area warna hijau muda di antara warna hijau tua di bawah. Responnya kepala 
binatang bertelinga panjang atau bertanduk panjang. Dengan white space-nya merupakan tubuhnya dan titik berwarna hijau tua merupakan matanya, misal :

- Seperti kepala kelinci.

\section{b. $\mathrm{O}$ (Original response)}

Berupa response-response yang jarang dikenal orang (sekitar 1 orang dari 100 orang pada areaarea tertentu). Bila konsep $\mathrm{O}$-nya tidak tepat, kabur dan kelihatan ganjil, maka diberi skor dengan simbol O-.

Contoh skor $\mathrm{O}$

- Kartu II : Kera dikebun binatang.

- Kartu III : Bag pipe

- Kartu V : Seperti iblis bertanduk dan berkaki yang bersembunyi di teluk.

Contoh skor $\mathrm{O}$ -

- Kartu VI : Kura-kura berkepala banyak yang sudah mati. 
- Kartu VIII : Seperti manusia yang berenang dibawah air dan berjabatan tangan dengan kodok.

- Kartu X : Di bawah tampak putra mahkota, ratu dengan mahkota-nya dan bergaun panjang dan berkaki empat.

\section{E. FLR}

Skoring terhadap jawaban yang diberikan subyek berdasarkan beberapa pertimbangan. Apakah jawabannya memiliki bentuk yang tepat dan sesuai dengan area yang digunakan.

Skor ini mengindetifikasikan kapasitas seseorang didalam me-lakukan sesuatu dengan caracara tertentu yang teryata mencerminkan perilaku intelektual rutin dari subyek :

a) Rata-rata FLR, mengetahui actual behavior (perilaku yang sudah diaktualisir).

b) Weighted average FLR, mengetahui subyek potential (potensi yang dimiliki subyek).

Tiap respon berkisar pada skor $-2,0$ (terendah) s/d $+5,0$ (skor tertinggi). 
E.1. Pertimbangan penilaian FLR, berdasarkan pada :

1) Accuracy : ketepatan

2) Spesification : penjelasan

3) Organization : penyusunan

Keterangan lebih detil tentang dasar pertimbangan dalam penilaian FLR sebagai berikut :

a. Accuracy : berkaitan dengan kesesuaian atau ketepatan konsep terhadap area percikan, dalam hal garisgarisnya, luas areanya dan bentuknya.

Di sini dilihat apakah konsepnya punya garis-garis luas area atau bentuk yang tepat dengan bentuk sebenarnya.

Ada 3 taraf akurasinya :

\section{1) Respon yang akurat}

Konsep yang adekuat atau yang lebih baik, yaitu konsep / jawaban yang sesuai dengan area yang digunakan. Konsep/jawaban seperti ini bisa diberi skor 1,0 atau lebih tinggi, misal : 
Kartu III : Kupu - kupu (area merah tengah).

Kartu IX : Tukang sihir (area orange atas).

\section{2) Respon yang setengah jelas}

Konsep yang kurang/setengah jelas, yaitu obyek yang kabur / kurang jelas. Konsep ini bisa dinilai antara 0,0 0,5 . Misal :

Kartu VII : Kabut

Kartu IX : Bunga

\section{3) Respon yang tidak tepat}

Konsep yang dangkal / tidak tepat, yaitu konsep yang berbentuk jelas tapi area yang digunakan tidak sama. dinilai minus, antara $-0,5 \mathrm{~s} / \mathrm{d}-2,0$. Misal :

Kartu VII : Rumah (W)

Kartu IV : Ular (W)

Kartu VII : Kabut saat matahari terbenam (area pink)

b. Spesification : Berkaitan dengan cara subyek menguraikan atau 
menggambarkan konsep

yang dilihat.

Jika uraiannya sesuai akan memperjelas konsep, demikian sebaliknya.

Ada 3 taraf spesification :

\section{1). Spesifikasi yang konstruktif}

Uraian terhadap konsepnya dengan menggunakan struktur percikan tertentu (misal, pada kartu VI : kumis pada kucing), atau menjelaskan detail dari roman muka atau menjelaskan kualitas movement, shading dan color dari percikan (misal, kartu IV : seseorang yang sedang me-ngendarai sepeda motor, seperti kalau kita lihat dari depan dan dari bawah).

\section{2). Spesifikasi yang kurang relevan}

Penjelasan terhadap malah mengurangi akurasi / ketepatan penggunaan percikannya, misal :

Kartu III : Tampak seseorang sedang membungkuk. Tetapi kemudian mengatakan 
memperjelas.

\section{3). Spesifikasi yang merusak}

Penjelasannya malah merusak FLR konsepnya, misal :

Kartu X : Seperti ulat (area hijau bawah) yang keluar dari mata kelinci.

$\rightarrow$ merusak konsep P - nya

c. Organization : Melihat bagaimana subyek mengorganisir bagian-bagian ink blot menjadi konsep yang lebih berarti.

Misal, pada kartu I : Dua orang menari mengitari sesuatu.

$\rightarrow$ tampak 2 sisi gambar diorganisir dengan bagian tengah (jadi $\mathrm{W}$ ), sehingga menjadi konsep yang berarti.

E.2. Proses skoring FLR, mengikuti 2 tahap :

1) Menetapkan Basal Rating (Nilai Dasar) Pemberian nilai basal/dasar (baik basal + atau -), berdasar (ter-utama) pada : 
accuracy / ketepatan bentuk respon / konsepnya.

2) Penambahan pada Basal Rating

Penambahan diberikan sebesar 0,5 untuk setiap spesifikasi / penjelasan / uraian yang baik dan untuk penyusunan / organisasi. Konsep yang dangkal /tidak tepat /kabur, yang malah menga-burkan / tidak memperjelas konsep / jawaban sebelumnya tidak mendapat penambahan, bahkan mendapat pengurangan.

Keterangan lebih detil tentang proses skoring FLR sebagai berikut

\section{1) Basal Rating}

Merupakan nilai awal yang diberikan untuk ketepatan bentuk konsep/respon yang diberikan subyek dengan area bercak yang dipilih.

Ada 7 basal rating yang bisa diberikan di awal penilaian FLR:

\section{a) Skor 1,0}

Skor ini merupakan skor kunci. Skor 1,0 ini sering diberikan untuk jawaban- 
jawaban yang punya bentuk yang jelas dan akurat / pas, termasuk 10 jawaban Populer (yang telah dijelaskan sebelumnya), dan jawaban-jawaban yang men-dekati popular, misal :

Kartu II : Kupu-kupu (area tengah bawah)

Kartu X : Dua ekor binatang kecil (area abu-abu atas)

\section{b) Skor 1,5}

Skor ini diberikan untuk jawaban / konsep yang punya bentuk lebih jelas dibanding yang bernilai 1,0. Konsep/jawabannya memiliki spesifikasi yang jelas, seperti : melihat raut muka manusia, figur manusia atau figur binatang tertentu,

Contoh :

Kartu I : Di tengah ini berdiri seorang wanita, dengan tangan terangkat dan membelakangi kita (area tengah). 
Kartu II : Dua anjing pudel saling memandang. Ini hidungnya, telinganya dan matanya (seluruh area hitam)

Kartu IX : Wajah seseorang. Lihatlah ini kepalanya, kening-nya hidungnya dan matanya (area hijau).

\section{c) Skor 0,5}

Skor ini diberikan pada jawabanjawaban yang punya bentuk yang kabur, atau setengah jelas tetapi tetap masih meng-gunakan kualitas bentuk (form), termasuk jawaban-jawaban dengan skor determinat : $\mathrm{CF}, \mathrm{C}$ F, $\mathrm{cF}$, $\mathrm{KF}, \mathrm{kF}, \mathrm{mF}$ dan respon $\mathrm{F}$ yang kabur, misal :

Kartu II : Seperti organ sex wanita, terkesan oleh warna merahnya, yang menunjukkan sobeknya selaput organ tersebut. 
Seperti yang ada di buku kedokteran, kelihatan samar-samar (area merah bawah).

Kartu VII : Sebuah batu karang yang berbeda-beda warna yang kita lihat dari atas (W).

\section{d) Skor 0,0}

Skor ini diberikan untuk konsep yang hanya memperhatikan determinan, tidak memperhatikan bentuk sama sekali, karena daerah bercak yang digunakan memang sangat kurang terstruktur, seperti tampak pada skor : C, Cdes, Cn, Csym, C', c, K, k, dan m, misal :

Kartu VII : Asap hitam. Inquiry : Perbedaan pewarnaan menyebabkan tampak seperti asap.

Kartu II : Bercak-bercak merah dan hitam. Inquiry : Se-perti 
apa, saya tidak bisa menjelaskan.

\section{e) Skor $(-1,0)$}

Skor pada penggunaan seluruh bercak namun secara dasar tidak akurat, sehingga berbagai upaya untuk memperbaiki justru terkesan dipaksakan.

Bisa juga, ada sebagian dari seluruh bercak yang digunakan sungguhsungguh akurat, namun ada beberapa spesifikasi yang sedemikian justru melemahkan sehingga konsepnya menjadi rusak, misal :

Kartu I : Secara keseluruhan seperti orang sedang duduk dengan lengan terjuntai. Inquiry : Yang samping ini adalah lengannya. Hanya merupakan kesan saja. 


\section{f) Skor $(-1,5)$}

Hampir sama dengan rating -1,0. Skor ini diberikan untuk respon confabulatory (respon yang diberikan terkesan meng-gunakan keseluruhan gambar, tetapi waktu inquiry hanya memberi alasan dengan mengambil sebagian gambar, skor DW), yang biasanya diberikan untuk pasien klinis, misal :

Kartu IV : Seekor ular (DW). Inquiry : Ini kepalanya dan lehernya. Ini merupa-kan bagian bawah dari ular

\section{g) Skor $(-2,0)$}

Skor ini diberikan untuk respon yang berisi konsep yang tidak cocok dengan daerah bercak yang digunakan dan tidak ada usaha subyek untuk memperbaiki respon, atau memberikan keterangan agar responnya sedikit menjadi lebih baik. 
Skor ini diberikan untuk responrespon perseverasi* dan kontaminasi*. Misalnya :

Kartu I : kelelawar

Kartu II : kelelawar

Kartu III : kelelawar, dst.

Disini jawaban diulang-ulang dan begitu sederhananya, karena tidak ada usaha untuk melakukan elaborasi (uraian lanjut) agar responnya bisa lebih masuk akal.

Contoh :

Kartu II : seperti anjing kecil. Inquiry : disini subyek tidak responsif untuk memperbaiki jawabannya.

Catatan :

*Respon perseverasi adalah respon yang diulang-ulang dan begitu sederhananya. Biasanya dijumpai pada anak-anak yang masih sangat kecil atau pasien klinis yang irrasional. 
*Respon kontaminasi adalah penggunaan 2 (dua) konsep definit yang sungguh-sungguh berbeda pada bercak yang sama, namun subyek memberi respon secara serius, dan ada kepuasan atas jawabannya.

\section{2) Adding Credit}

Setelah memberi basal rating (berdasar pertimbangan aku-rasi), maka selanjutnya adalah memberi tambahan nilai.

Pemberian tambahan nilai ini berdasarkan pada pertimbangan spesifikasi dan organisasi.

Setiap penambahan nilai adalah 0,5 , sehingga setiap spesifikasi yang berhasil akan diberi penambahan skor, sedangkan untuk pertimbangan organisasi diberi tambahan nilai 0,5 sekali saja.

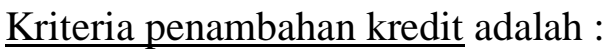

1. Spesifikasi yang diberikan harus bersifat spontan. Baik yang diberikan 
pada tahap performance proper maupun inquiry. Spesifikasi yang muncul karena dipancing dengan pertanyaan (oleh tester) tidak bisa mendapat tambahan kredit, karena sudah bersifat mengarahkan (directive).

2. Spesifikasi harus melebihi syarat minimum dari konsepnya, atau melebihi dasar esensial dari konsep / jawaban

3. Spesifikasi mencakup penggunaan determinant yang harus merupakan bagian esensial dari konsepnya (misal : warna hitam - untuk kelelawar ) dan melebihi batasan populer atau karakteristik dasar akan menambah kredit. Kalau pada basal rating sudah diberi 1,5, maka penyebutan warna (warna hitam di atas) tidak menambah kredit lagi.

4. Spesifikasi yang diberikan harus independen atau terpisah (misal : mata 
dan bulu mata merupakan satu spesifikasi konstruktif sehingga hanya diberi satu kali penambahan sebesar $0,5)$

5. Prosedur organisasional yang mendapat tambahan kredit ada-lah yang menggabungkan beberapa konsep dalam satu konsep yang lebih besar, harus menambah makna tertentu.

Berkaitan dengan adding credit di atas, spesifikasi yang bisa menambah kedit adalah spesifikasi yang konstruktif (yaitu elaborasi atas konsep akan semakin meningkatkan ketepatan dalam penggunaan kualitas area bercak). Semakin konstruktif spesifikasi yang diberikan semakin jelas tampak bahwa subyek mampu melakukan diferensiasi persepsi tingkat tinggi.

Spesifikasi yang demikian meliputi :

1. Spesifikasi bentuk, yaitu penggunaan kualitas struktural bercak sehingga 
konsepnya semakin sesuai dengan outline dari bercak.

Spesifikasi ini harus sesuai dengan realitas yang sebenarnya, misal : menyebut kumis pada kucing, tampilan wajah pada manusia (minimal bisa menyebut 3 karakteristik)

2. Spesifikasi determinan, yaitu penggunaan kualitas warna, sha ding, dan gerakan pada bercak.

a. Spesifikasi gerakan, dengan kriteria

(1) gerakan harus dalam konteks bentuk yang definit, misal : $\mathrm{M}$, FM, Fm

(2) harus didukung adanya bercak tinta yang nyata.

b. Spesifikasi shading dan warna, dengan kriteria :

(1) shading dan warna dikombinasi dengan konsep de-finit, 
(2) shading dan warna merupakan unsur yang esensial dari konsepnya. 


\section{Kesimpulan}

Respon yang dibuat subyek ada 2 macam : Main Response, dan Additional Response.

Ada 2 macam skor : Main-score diberikan untuk setiap mainresponse untuk : location, determinant, content, $P-O$, dan FLR, dan Additional-score untuk : (1) pemberian rincian atau spesifikasi main response pada saat performance proper maupun saat inquiry, (2) respon pada tahap performanceproper yang di-reject oleh testee sendiri ketika inquiry, (3) pemberian hubungan atau rincian baru pada tahap inquiry terhadap respon yang diberikan di performance proper, (4) penggunaan kualitas-kualitas pada inquiry (pada skor determinant) secara tidak sengaja.

Ada 5 kategori skoring atas respon testee : (1) Location : skor untuk area mana dari kartu yang direspon, (2) Determinant : skor untuk kualitas dari respon, (3) Content : skor untuk menentukan apa isi respon subyek/tentang apa isi responnya, (4) Populer-Original : skor yang menentukan apakah respon subyek termasuk respon-respon yang populer atau jarang terjadi, (5) Form Level Rating : skor untuk ketepatan (akurasi) konsep yang dilihat. Apakah jawaban / konsep tersebut sesuai dengan area yang digunakan. 
Skor lokasi terdiri dari : (1) W : penggunaan seluruh bercak tinta, (2) D : penggunaan sebagain besar bercak tinta dan sering digunakan individu, (3) d : penggunaan sebagian kecil bercak tinta dan sering digunakan individu, (4) Dd : penggunaan sebagian kecil bercak tinta dan jarang digunakan individu, (5) $\mathrm{S}$ : penggunaan area putih.

Skor determinant, terdiri dari : (1) F : penggunaan "bentuk" sebagai alasan jawaban, (2) M,FM,m : penggunaan "gerakan" sebagai alasan jawaban, (3) c,k.F : penggunaan "shading" sebagai alasan jawaban, (4) C,C' : penggunaan "warna" sebagai alasan jawaban.

Skor content, merupakan skor yang diberikan untuk isi jawaban subyek.

Skor P-O, skor penentuan apakah jawaban testee tergolong populer atau original.

Skor FLR, skoring terhadap jawaban yang diberikan subyek, apakah jawabannya memiliki bentuk yang tepat dan sesuai dengan area yang digunakan. 


\section{Latihan soal :}

1. Jawaban subyek bisa dimasukkan kedalam 2 kategori respon. Jelaskan kedua kategori tersebut !

2. Skor apa saja yang bisa diberikan untuk setiap jawaban/konsep yang dibuat subyek ? jelaskan !

3. Beri skor untuk jawaban-jawaban di bawah :

a. Kartu I : Mahkota raja (kartu dibalik, seluruh area). Inquiry : bentuknya seperti mahkota yang biasa dipakai seorang raja. Di mahkotanya ada permata-permata yang menonjol (sambil menunjuk bagian-bagian menonjol)

b. Kartu III : Seperti pita rambut warna merah (bagian merah tengah). Inquiry : bentuknya seperti pita rambut, berwarna merah

c. Kartu VIII : Harimau berjalan mendaki (area pink samping). Inquiry : Terlihat empat kakinya, kepalanya mendongak, dan ada ekornya.

\section{Referensi :}

Klopfer, B \& Davidson, H.H, 1962. The Rorschach Technique. An Introduction Manual. Harcourt, Brace, \& World, Inc., New York, USA.

Subandi \& Ratna Wulan, 2005. Tes Rorschach. Administrasi dan Skoring. Fakultas Psikologi UGM, Yogyakarta. 
Phillips, L. \& Joseph G. Smith, 1963. Rorschach Interpretation : Advanced Technique. Grune \& Stratton, New York, USA. 


\section{BAB VI \\ TABULASI HASIL TES}

\section{Kemampuan Akhir Yang Direncanakan :}

Setelah mempelajari bab ini,

diharapkan mahasiswa

mampu memahami setiap bagian dari tahap tabulasi

dan melakukan tabulasi hasil skoring tes Rorschach

Tahap tabulasi dilakukan untuk interpretasi kuantitatif, meliputi Tabulation and Scoring Sheet, Psychogram, \& Relationships Among Factors. 


\section{VI.A. Tabulation And Scoring Sheet}

Lembar skoring dan tabulasi yang digunakan disederhanakan sebagai berikut :

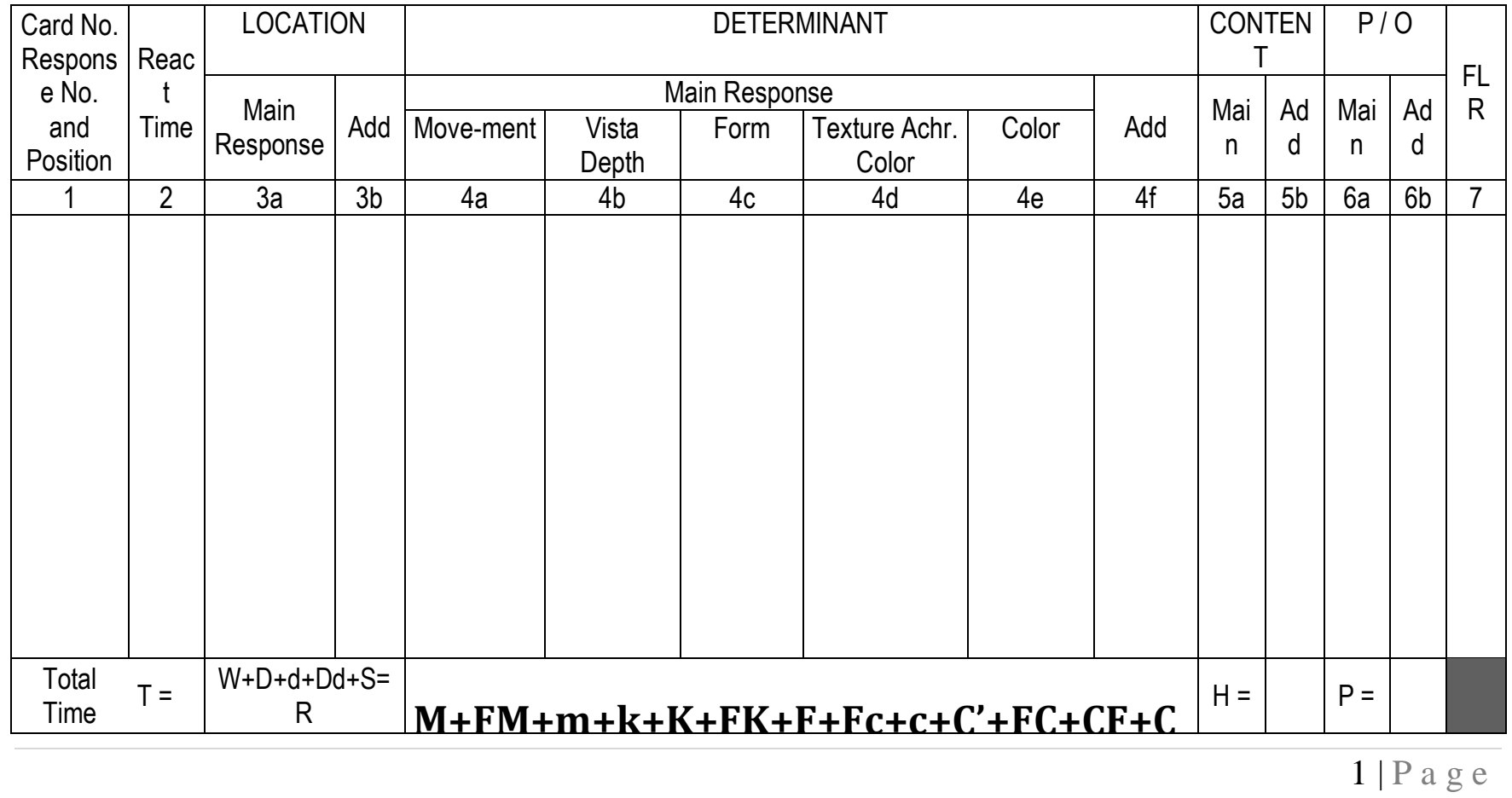




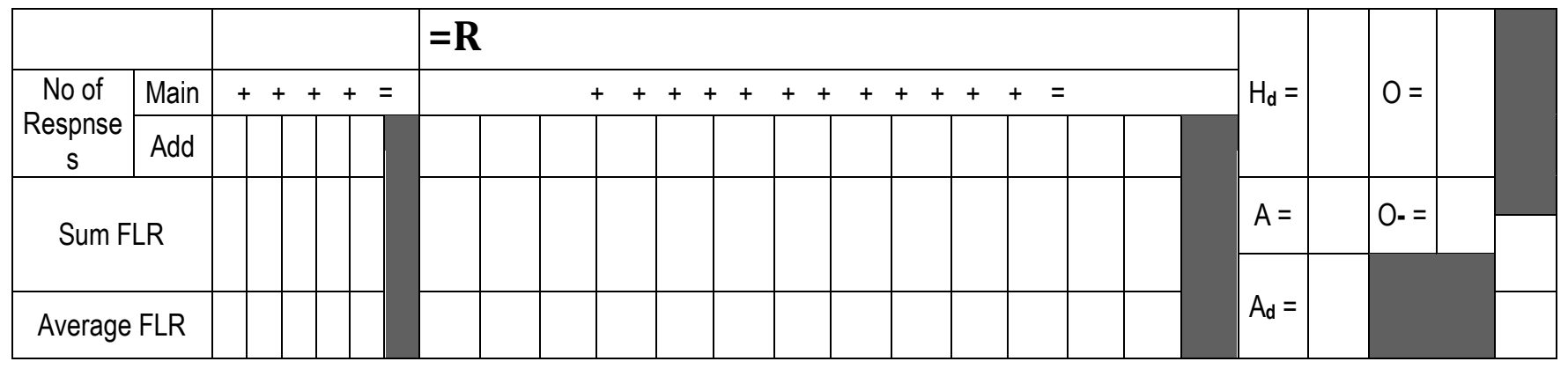


Keterangan cara pengisian masing-masing kolom adalah sebagai berikut :

Kolom 1Diisi dengan nomor kartu dengan angka Romawi (I, II, III, dst), nomor respons dengan angka Arab (1,2,3,dst). Untuk tanda posisi, yang paling penting dicatat adalah posisi untuk respons pertama setiap kartu (respons nomor 1) dan untuk selanjutnya, tanda posisi hanya diberikan kalau ada perubahan dari posisi respons pertama. Jadi tidak perlu setiap respons diberikan tanda posisinya.

Setelah semua respon untuk satu kartu, maka diberi garis horisontal yang membatasi respons-respons satu kartu dengan responsrespons pada kartu yang lainnya.

Kolom 2 Diisi dengan waktu reaksi dalam satuan detik. Ada baiknya untuk mencatat juga waktu respons keseluruhan per kartu (mulai dari kartu dibukakan pada tahap performance proper sampai dengan subjek mengatakan "sudah" atau "selesai" dan ia berhenti memberikan respon).

Pada bagian bawah, dicatat waktu tes total (T) yaitu keseluruhan waktu yang digunakan 
untuk tahap performance proper. Dicatat dalam satuan menit dan detik.

Kolom 3a Diisi dengan skor lokasi untuk main response, berarti hanya satu skor lokasi untuk satu main response.

Kolom 3b Diisi dengan skor additional location untuk semua jenis lokasi tambahan (W, D, d, S, dan sebagainya). Skor lokasi ini diberikan untuk respons tambahan yang baru muncul pada inquiry, respons pada PP yang ditolak sewaktu pada inquiry, dan sebagainya.

Kolom 4a Determinant pokok untuk movement. Termasuk di sini adalah $\mathbf{M}, \mathbf{F M}, \mathbf{F m}, \mathbf{m F}, \mathbf{m}$. Namun dalam penjumlahan respons, hanya dikelompokkan menjadi 4 kategori. Respons $\mathbf{m F}$ dan $\mathbf{m}$ digabung ke dalam kelompok $\mathbf{m}$.

Kolom 4b Determinant pokok untuk vista/depth. Termasuk di sini adalah respon $\mathbf{F K}, \mathbf{F k}, \mathbf{K F}, \mathbf{k F}, \mathbf{K}$ dan $\mathbf{k}$. Untuk kolom jumlah respon, $\mathbf{k F}+\mathbf{k}$ dikelompokkan dalam skor $\mathbf{k}, \mathbf{K F}+\mathbf{K}$ dikelompokkan dalam skor $\mathbf{K}$ 
Kolom 4c Determinant pokok untuk form. Termasuk di sini semua jenis $\mathbf{F}$, baik $\mathbf{F}+, \mathbf{F}$, maupun $\mathbf{F}$-, jadi tanpa memandang akurasi bentuk.

Kolom 4d Determinant pokok untuk texture \& achromatic color. Termasuk di sini respon Fc, cF, c dan FC', C'F dan C' dikelompokkan dalam respons C'.

Kolom $4 \mathrm{e}$ Determinant pokok untuk chromatic color. Termasuk di sini adalah skor FC, CF dan $\mathbf{C}$. Dalam penjumlahan, ketiganya dipisah seperti adanya menjadi tiga kelompok skor $\mathbf{F C}, \mathbf{C F}$ dan C.

Kolom 4f Semua skor additional determinant dimasukkan dalam kolom ini. Bisa jadi dalam satu respons main terdapat lebih dari satu skor respon additional. Kalau ada lebih dari satu determinan additional, maka dipisahkan dengan tanda koma. Bisa juga ditulis di bawahnya, kalau kolom kurang ruang.

Kolom 5a Disini dicantumkan content pokok. Hanya ada satu untuk setiap main response.

Kolom 5b Diisi semua content tambahan dalam kolom ini. 
Kolom 6a Meskipun banyak respons tidak ada skor P atau $\mathrm{O}$, namun kalau ada maka main popular/original diletakkan disini. Untuk yang masih belajar, seperti kita, tidak perlu mencantumkan skor $\mathrm{O}$, hanya skor P saja.

Kolom 6b Pada kolom ini diisikan kecenderungan $\mathrm{P}$ atau $\mathrm{O}$ $(\rightarrow \mathrm{P}, \rightarrow 0)$. Tanda panah, dimulai dari kolom 6a (main P/O). Sedangkan huruf P/O diletakkan pada kolom 6b (additional). Juga termasuk di sini adalah skor $\mathrm{P} / \mathrm{O}$ untuk skor respon additional locations.

Kolom 7 Untuk FLR tidak dibedakan antara respons main dan additional. Namun pemeriksa hendaknya tahu mana yang main dan mana additional, berdasarkan pada skor lokasi, determinant, content, dan $\mathrm{P} / \mathrm{O}$.

Catatan : Untuk menandai beberapa main respons maka pada lokasi main diberi tanda penggabung. Kalau disertai dengan additional location, maka diletakkan pada kolom additional location.

Contoh :

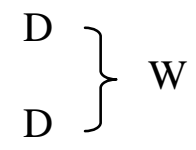


Dalam hal ini ada dua main respons (D dan D) yang diletakkan pada main location, sedangkan $\mathrm{W}$ diletakkan pada additional location.

\section{VI.B. Psikogram}

Setelah tabulasi skor dibuat, maka untuk determinan dipindahkan pada psikogram, sehingga ada visualisasi yang dapat dilihat secara lebih jelas. Untuk membuat psikogram, disediakan ruang diatas skor determinan.

Yang harus diperhatikan adalah pengelompokkan atau klasifikasinya :

1. Termasuk dalam skor $\mathbf{m}$ : skor Fm, $\mathrm{mF}$ dan $\mathrm{m}$

2. Termasuk dalam skor $\mathbf{k}$ : skor Fk, kF dan k.

3 Termasuk dalam skor $\mathbf{K}$ : skor KF dan $\mathrm{K}$ (di bawah skor FK ).

4. Termasuk dalam skor $\mathrm{c}$ : skor $\mathrm{cF}$ dan $\mathrm{c}$ (skor FC sendiri )

5. Termasuk dalam skor C' : skor FC', C'F dan C'.

6. Termasuk dalam skor $\mathbf{C}$ : skor $\mathrm{C}, \mathrm{C}_{\mathbf{n}}, \mathrm{C}_{\mathbf{d e s}}$, dan $\mathrm{C}_{\text {sym }}$. 
Dalam membuat grafik psikogram, dibedakan antara main score dan additional score.

1. Main score : dijumlah sesuai dengan kategori yang sudah ditentukan (M, FM, m, k, dan seterusnya), kemudian diberi tanda titik tetal. Kemudian dibuatgrafik bar atau histogram dengan garis lurus bersambung ( ). Untuk skor pokok ini, unitnya adalah satu respon sama dengan satu tingkat (jarak antara titik satu dengan titik di atasnya). Angka yang menunjukkan jumlah diletakkan di dalam grafik.

Kalau grafiknya memungkinkan (misalnya karena jumlah skor determinan sedikit), maka unitnya bisa 2 .

2. Additional score, skor tambahan ini dijumlah, kemudian digambar grafik bar/ histogram-nya yang dihubungkan dengan garis pisah-pisah $(--=--)$.

Contoh :

VI.C. Relationships Among Factors

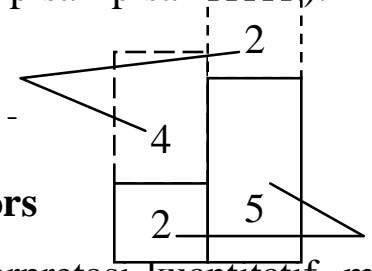

Untuk memudahkan interpretası kuantıtatıf, maka hubungan antar faktor ini perlu d: M FM bungan 
antar faktor dibedakan menjadi dua : basic relationship dan supplementary relationships.

\section{Basic Relationship (Hanya Menggunakan Skor}

\section{Main Saja)}

Dalam menghitung basic relationships hanya dipakai skor pokok saja, agar tetap dapat diperbandingan dengan versi asli dari Hermann Rorschach, karena Rorschach tidak memperhitungkan skor tambahan.

Respons total $(R)$

Waktu total $(T)$

Rata-rata waktu per respons $(T / R)$

Rata-rata waktu reaksi kartu Akromatik

Rata-rata waktu reaksi kartu Kromatik
Jumlah main respon

Waktu keseluruhan untuk tahap performance proper (PP) dihitung dalam satuan menit dan detik.

T dibagi $\mathrm{R}$, dihitung dalam satuan detik

Hasil pembagian antara jumlah waktu reaksi

Untuk kartu akromatik (Waktu reaksi I + IV + $\mathrm{V}+\mathrm{VI}+\mathrm{VII})$ dibagi 5, dihitung dalam satuan detik

Hasil pembagian antara jumlah waktu reaksi Untuk kartu kromatik (Waktu 
reaksi II + III +

$\mathrm{VIII}+\mathrm{IX}+\mathrm{X}$ ) dibagi 5 , dihitung dalam

satuan detik

F\%

Jumlah semua main response F dibagi jumlah

Main response (R) dikalikan seratus.

$\frac{F K+F+F c}{R} \%$

Sudah jelas

A\%

Jumlah main response yang content-nya A

dan Ad dibagi dengan main response $(\mathrm{R})$

$(H+A):(H d+A d) \quad$ Sudah jelas

Respons popular

Jumlah respon popular yang main dan additi

onalyang dipisahkan dengan koma atau addi

tional $\mathrm{P}$ diberi tanda kurung ( )

Respons orisinal

Sum $C^{\prime}$

Jumlah respon popular baik main maupun

additional

: Skor yang diperoleh dengan rumus sebagai

berikut : $\frac{F C+2 C F+3 C}{2}$ 


$$
\begin{aligned}
& M: \text { Sum } C \quad: \text { Sudah jelas } \\
& (F M+M) \quad: \quad: \text { Sudah jelas } \\
& \left(F C+C+c^{\prime}\right) \\
& (V I I I+I X+X) \% \quad: \text { Proporsi respon kromatik } \\
& \text { murni (VIII,IX,X) } \\
& \text { dibandingkan respon } \\
& \text { keseluruhan (R). Jumlah } \\
& \text { kan main response pada } \\
& \text { ketiga kartu terakhir, } \\
& \text { kemudian dibagi dengan } \mathrm{R} \\
& \text { dan dikalikan } 100 . \\
& \text { Buat catatan tambahan, } \\
& \text { kalau jumlah respons } \\
& \text { untuk kartu } \mathrm{X} \text { sendiri } \\
& \text { melebihi } 20 \% \text { dari R. } \\
& W: M \quad: \quad \text { Sudah jelas }
\end{aligned}
$$

2. Supplementary Relationship (Menggunakan Skor Main + 1/2 Skor Additional)

Dalam hal ini, baik respons pokok (main) maupun tambahan (additional) digunakan, maupun respons tambahan hanya diberi bobot setengah saja.

$M: F M$

Sudah jelas (kalau ada skor tambahan, maka jumlah yang dimasukkan dalam perbandingan adalah $1 / 2 \times \Sigma$ respons (M atau FM) 


\begin{tabular}{|c|c|}
\hline$M:(F M+m)$ & Sudah jelas \\
\hline$(F K+F c): F$ & Sudah jelas \\
\hline Akromatik : Kromatik & $\begin{array}{l}\text { Jumlahkan skor-skor kartu } \\
\text { akromatik } \\
\left(\mathrm{Fc}, \mathrm{cF}, \mathrm{c}, \mathrm{FC}, \mathrm{C}^{\prime} \mathrm{F}, \mathrm{C}^{\prime}\right) \text {. } \\
\text { dibandingkan de-ngan hasil } \\
\text { penjumlahan skor-skor kartu } \\
\text { kromatik (FC,CF,C). }\end{array}$ \\
\hline
\end{tabular}

Differrentiated : Jumlahkan skor-skor Undifferrentiated shading yang terdiferensiasi Shading (FK,Fk,Fc). Bandingkan dengan skor-skor shading tidak ter-diferensiasi $(\mathrm{K}, \mathrm{KF}, \mathrm{k}, \mathrm{kF}, \mathrm{c}, \mathrm{cF})$

$F C:(C F+C) \quad$ Sudah jelas

\section{VI.D. Manner Of Approach}

Prosentase berbagai skor lokasi berhubungan dengan pendekatan intelektual terhadap masalah. Setiap kategori skor lokasi dicari prosentase-nya. Prosentase skor lokasi yang sudah ada dimasukkan dalam kolom sesuai besarnya prosentase skor lokasi yang ada.

Selanjutnya, dibandingkan dengan prosentase skor lokasi yang diharapkan. Prosentase skor lokasi yang diharapkan adalah W (20\% - 30\%), D (45\% - 55\%), d ( $5 \%-15 \%)$, dan Dd+S $(<10 \%)$. 


\section{VI.E. Suksesi}

Suksesi berkaitan dengan keurutan lokasi yang digunakan untuk memberi respon. Respons yang sistematis mengikuti urutan sebagai berikut : W-D-dDd (atau S). Bisa juga sebaliknya Dd (atau S)-d-D-W. Tidak harus semua lokasi ada, misal : respons yang sistematis adalah W-D atau W-D-d-Dd atau W-D-d-S. Untuk dapat menentukan sistematis atau tidak, minimum harus ada 2 respons pokok dengan lokasi yang berbeda (W dan $\mathrm{D}, \mathrm{D}$ dan $\mathrm{d}$, D dan dd, dan sebagainya).

Kalau di satu kartu hanya ada satu respons atau satu jenis lokasi (D saja, d saja, W saja, dan sebagainya), maka tidak dapat ditentukan apakah sistematis atau tidak sistematis. Respons demikian dimasukkan.dalam kategori ambigous (bisa sistematis bisa tidak sistematis). Yang penting dijumlah beberapa yang sistematis, beberapa yang tidak sistematis, sedangkan yang ambiguous diabaikan. Setelah diketahui beberapa kartu sistematis dan berapa yang tidak sistematis, ditentukan mana yang lebih banyak. 
Kemudian kartu yang ambiguous ditambahkan pada yang lebih banyak (sistematis atau tidak sistematis).

Kalau jumlah kartu sistematis dan tidak sistematis sama, maka kartu ambiguous tidak diperhitungkan, yang dipakai untuk menentukan suksesi hanyalah kartu yang sistematis saja.

Ada empat kategori untuk suksesi :

1. Rigid succession (suksesi kaku) semua kartu sistematis.

2. Orderly succession (suksesi teratur) : ada 7 s/d 9 kartu sistematis.

3. Loose succession (suksesi longgar) : ada 3 s/d 6 kartu sistematis.

4. Confused succession (suksesi kacau) : kurang dari 3 kartu sistematis.

Interpretasi tentang suksesi selengkapnya dapat dilihat pada bab yang membahas tentang interpretasi kuantitatif.

\section{VI.F. Form-Level Rating}

FLR yang menunjukkan kualitas respons, perlu dihitung rata-ratanya untuk hal-hal sebagai berikut : 
1. Rata-rata FLR tak terbobot (average unweighted FLR)

2. Rata-rata FLR terbobot (average weighted FLR)

3. Rata-rata FLR untuk kartu kromatik dan akromatik.

4. Rata-rata FLR untuk masing-masing kategori determinan.

5. Rata-rata untuk masing-masing kategori lokasi.

Untuk rata-rata FLR yang ketiga, keempat, kelima kiranya sudah jelas. Yang perlu dijelaskan lagi adalah rata-rata FLR tak terbobot dan terbobot.

Untuk mencari rata-rata FLR tak terbobot digunakan aturan sebagai berikut : Jumlahkan FLR untuk semua respons (main dan additional) dibagi dengan jumlah respons (main dan additional).

Atau diwujudkan dalam rumus :

$$
\begin{aligned}
& \text { Average unweighted FLR } \\
& \frac{\Sigma F L R_{\text {main }+ \text { add }}}{\Sigma R_{\text {main }+ \text { add }}}
\end{aligned}
$$

Untuk mencari rata-rata FLR terbobot, digunakan pedoman sebagai berikut : Jumlah FLR yang skornya 2,5 atau lebih dikalikan 2 ditambah jumlah FLR yang skornya kurang dari 2,5 dibagi oleh respons total 
(main dan additional). Kalau diwujudkan dalam rumus adalah sebagai berikut :

$$
\begin{aligned}
& \text { Average weighted FLR= } \\
& \frac{\sum\left\{\left(F L R_{\text {main }+ \text { add }} \geq 2,5 \times 2\right)+\Sigma(F L R<2,5)\right\}}{\Sigma R_{\text {main }+ \text { add }}}
\end{aligned}
$$

\section{Kesimpulan}

Psikogram merupakan visualisasi dari seluruh skor determinat, baik main maupun additional score.

Suksesi berkaitan dengan keurutan skor lokasi yang didapat subyek dalam satu kartu, dan standar keurutannya adalah WD-d-Dd (atau S) atau kelaikannya Dd (atau S)-d-D-W.

Manner of Approach dilengkapi dengan mencari prosentase masing-masing skor lokasi, dan memasukkan prosentase skor lokasi sesuai kolom besarnya prosentase.

\section{Latihan soal :}

Seorang klien dites kepribadian dengan tes Rorschach, dan skor yang didapat :

a. skor lokasi : $\mathrm{W}=5 ; \mathrm{D}=10 ; \mathrm{d}=3 ; \mathrm{dr}=2 ; \mathrm{S}=3$

b. skor determinan : $\mathrm{M}=4 ; \mathrm{F}=12 ; \mathrm{Fc}=2 ; \mathrm{FC}^{\prime}=2 ; \mathrm{FC}=2$;

$$
\mathrm{C}=1
$$


Dari data di atas :

1. Buat grafik Psikogram-nya!

2. Isi kolom manner of approach-nya!

3. Suksesi-nya termasuk kategori apa?

\section{Referensi :}

Klopfer, B \& Davidson, H.H, 1962. The Rorschach Technique. An Introduction Manual. Harcourt, Brace, \& World, Inc., New York, USA.

Subandi \& Ratna Wulan, 2005. Tes Rorschach. Administrasi dan Skoring. Fakultas Psikologi UGM, Yogyakarta.

Phillips, L. \& Joseph G. Smith, 1963. Rorschach Interpretation : Advanced Technique. Grune \& Stratton, New York, USA. 


\section{BAB VII \\ INTERPRETASI}

\section{Kemampuan Akhir Yang Direncanakan : \\ Setelah mempelajari bab ini, \\ diharapkam mahasiswa mampu \\ memahami dan menerapkan \\ bagaimana menginterpretasi hasil}

tes Rorschach dengan interpretasi

kuantitatif

Dalam proses menginterpretasi hasil tes secara kuantitatif, ada 2 (dua) proses interpretasi, yaitu :

\section{VII.1. Interpretative Meaning Of The Categori Scoring (Interpretasi untuk Masing-Masing Kategori} Skoring)

Bagian ini membahas interpretasi terhadap skor yang didapat pada masing-masing kategori skor, yang meliputi interpretasi:

(I) skor lokasi, (II) skor determinan, (III) skor konten,

(IV) skor popular-original, dan (IV) skor FLR.

seperti dijelaskan di bawah :

\section{A. Skor Lokasi}


- Pada umumnya, interpretasi skor LOKASI berhubungan dengan :

Intellectual manner of approach, yaitu : cara-cara yang biasa digunakan individu didalam menyelesaikan/menghadapi sesuatu.

- Pendekatan intelektual seseorang terhadap masalah yang dihadapi meng-gambarkan bagaimana kebiasaan individu menghadapi atau bereaksi terhadap seperangkat data, apakah dengan cara : deduktif atau induktif, memandangnya secara global atau hanya memperhatikan hal yang kecil-kecil, dengan atau tanpa memperlihatkan kejelasan.

- Hendaknya diperhatikan bahwa W\% tinggi dengan FLR baik bersama-sama dengan D\% normal, akan berbeda artinya dengan W\% tinggi dengan FLR rendah dan tanpa $\mathrm{D}$, sehingga harus diperhatikan faktor-faktor lain yang berkaitan dengan skor tersebut, misal : bila data skor subyek menunjukkan :

$$
\begin{aligned}
& 20-30 \% \mathrm{~W}, 45-55 \% \mathrm{D}, \\
& \begin{array}{l}
\text { Pendekatan intelektualnya } \\
5-15 \%,<10 \% \mathrm{Dd}+\mathrm{S} \\
\text { seimbang. }
\end{array}
\end{aligned}
$$

\section{I.1. Hipotesa W\% :}

* Dewasa normal : $20 \%-30 \%$ 
* $\mathrm{W} \geq 30 \%$ dengan kualitas W baik (FLR W baik/tinggi), menggambarkan :

Kemampuan seseorang didalam mengorganisir "materi", menggabung-kan "bagian-bagian" dalam keseluruhan, dan lebih memperhatikan kemampuan abstrak dan teoritis seseorang.

* Bila W>30\% dikombinasi dengan FLR sedangsedang :

Individu berambisi ke arah $\mathrm{W}$ tetapi tidak diimbangi kemampuannya.

* Bila kurang menekankan respon $\mathrm{W}(\mathrm{W}<20 \%)$ :

Cenderung kurang ada minat "mencari" relationship/hubungan di antara fakta-fakta yang dialaminya/dihadapinya.

* Jawaban $\mathrm{W}$ di atas rata-rata

1. Intelektual tinggi, terutama jika W yang dihasilkan berkualitas baik.

2. Ambisi intelektual tinggi

$\rightarrow$ Pada keadaan ekstrim : dorongan paksa mencapai prestasi intelektual bercorak kompulsif, mungkin sebagai defens untuk kompensasi. 
3. Pengamatan yang terorganisir dan terintegrasi baik.

4. Energi kuat, energik.

5. Menjadi lebih peka terhadap pujian dan kritikan.

6. Pada $\mathrm{S}$ wanita : kecenderungan menggeneralisir, berambisi dan se-mangat maskulin.

* Jumlah W di bawah rata-rata

1. Pengamatan yang tak terorganisir dan tak terintegrasi.

2. Anxiety dan stress, sering-sering membawa akibat tingkah laku constrictive.

3. IQ rendah, retardasi mental, atau kondisi depressip.

4. Kurang inisiatif atau aspirasi rendah.

5. Repressi.

6. Brain damage.

7. Schizophrenic condition.

* Jumlah $\mathrm{W}$ rata-rata

1. Kepribadian normal, persepsi dan intelektual berkembang serasi. 
2. Sanggup bersikap realistik dalam menghadapi persoalan sehari-hari.

* Penggunaan WXmenunjukkan :

1. Sifat kritis subyek (di bidang intelektual), sehingga mendorong indi-vidu mengabaikan hal-hal yang tidak fit/pas menurutnya.

2. Sifat kritik yang berlebihan (over-criticalness) yang cenderung mem-pengaruhi fungsinya/proses berpikirnya.

3. Anxienty, tension, ragu-ragu.

* Penggunaan DW menunjukkan :

1. Kelemahan subyek didalam memperesepsi realita, (reality testing kurang baik).

2. Kecenderungan terlalu menggeneralisir (overgeneralize) tanpa me-naruh perhatian secara teliti terhadap detil-detilnya, yang cenderung mengarah pada pengambilan kesimpulan yang keliru.

3. Psikosis, terutama skizofren.

4. Reasoning, daya timbang lemah, seperti yang lazim ditunjukkan pada anak-anak normal atau psikopat dewasa.

5. Organicity. 
6. Retardasi mental.

* Penggunaan $(\rightarrow W)$ menunjukkan :

- Minat terhadap pemikir teoritisnya, tetapi kurang berhasil dalam praktek mengorganisirnya.

* $\mathrm{W}+$

- Intelligensi superior.

- Persepsi baik, pola berpikir abstrak.

- Kontra indikasi untuk anxiety.

* $\mathrm{W}-$

1. Intelektual tidak berfungsi baik.

2. Level Aspirasi terlalu tinggi, dapat sebagai kompensasi atau me-rupakan dorongan kompulsif.

3. Maladjusting personalities, penyesuaian diri tidak baik.

4. Ada kerusakan otak (brain damage).

5. Lebih banyak ditemukan pada schizophrenic condition daripada neurotic.

\section{I.2. Hipotesa D\% dan d\% :}

* D\% dewasa normal : $45-55 \%$, dan untuk d\% dewasa normal : $5-15 \%$

* Umumnya, menunjukkan adanya minat terhadap : 
Hal-hal yang spesifik, detail, dan hal-hal yang kongkrit.

(dengan kata lain, skor ini mewakili penerapan fungsi intelegensi subyek dalam kondisi praktis dan sehari-hari).

* Bila terlalu menekankan D dan d dengan kombinasi FLR sedang atau tinggi :

- Individu merasa agak insecure (kurang aman), tidak yakin, tidak mantap, gelisah, dan baru merasa safest (paling aman) bila dia yang karenanya akan mencari selamat dengan cara tetap berpijak pada hal-hal yang baginya sudah pasti / jelas atau cara berada dekat dengan halhal yang nyata.

* Kurang menekankan D (berhubungan dengan over-emphasis $\mathrm{W})$, menekankan $\mathrm{W}$ atau $\mathrm{Dd}$, atau W dan Dd

$\rightarrow$ pada subyek dengan skor W kualitas rendah (dengan $\mathrm{W}$ vague dan unorganized) :

- $\quad$ Sering ditemui pada subyek dengan kemampuan intelektual poor atau mengalami gangguan emosi, misal : Schizophrenic. 
* Jumlah D di atas rata-rata

1. Praktis, common sense, kemampuan dan orientasi biasa-biasa saja, normal.

2. Pengamatan cukup baik namun tidak terorganisir secara istimewa.

3. Anxiety dan insecurity, perasaan tidak aman, gelisah, tidak mantap.

4. Depresif dan ada tendensi untuk bunuh diri.

5. Schizophrenic condition.

6. Pribadi constricted, berpegang kuat-kuat hanya pada hal-hal yang jelas saja.

* Jumlah D menyolok di bawah rata-rata

1. Kebiasaan pengamatan yang tidak adekuat atau lazim.

2. Gangguan emosional dan neurotic conditions.

3. Brain damage conditions.

* Jumlah D rata-rata

- Penyesuaian diri baik, adjusted, normal.

* Kualitas respon D baik (D+)

- S dengan intelektual superior yang insecure, merasa tidak pasti, tidak yakin, tidak aman. 
* Kualitas respon D rendah (D-)

- Intelegensi di bawah normal.

- Mengalami gangguan emosional, terutama bila D yang keluar juga hanya sedikit.

- Kondisi skizofren, terutama skizofren paranoid.

* Kualitas respon D rata-rata

- Penyesuaian diri baik, adjusted, normal.

* d \%

1. Penekanan pada d berkaitan dengan rasa tidak aman dan anxiety, kadang-kadang juga ditentukan pada $\mathrm{S}$ dengan pribadi kompulsif.

2. Banyak d dengan hanya sedikit $\mathrm{W}$ mencirikan sikap pasif dan inisiatif kurang, dihubungkan dengan skizofren dan cerebral organics.

* Bila d $>15 \%$, sering dihubungkan dengan :

- Pendatry (sikap suka menonjolkan ilmunya).

- Kebutuhan untuk selalu akurat/tepat, benar, dan pasti/teliti.

* Bila d <5\%, indikasinya :

- Sedikit minatnya terhadap hal-hal yang kecil.

\section{I.3. Hipotesa Dd\% dan S\% :}

* Dewasa normal Dd + S : $<10 \%$ 
* Dd dan $\mathrm{S}$ respon menunjukkan :

Kemampuan individu untuk menggunakan detildetil yang tidak umum. Hal ini biasanya menunjukkan individu ini :

1. Dd dengan FLR baik :

- Sangat responsif terhadap lingkungan.

- Sangat memperhatikan hal-hal yang umum/tidak umum.

2. Dd rendah atau nol ( $\mathrm{Dd}<10 \%$ atau 0$)$ :

- Lazim, tidak ada arti signifikan.

* Penekanan pada Dd + S

1. Anxiety.

2. Hubungan dengan realitas longgar.

3. Kecenderungan paranoid

* Hipotesa beberapa skor lokasi Dd\% dan S\% :

1. dd : Penekanan pada skor dd,

1. Gejala obsesif, pikiran-paksa, sangat teliti, pedant, sok ilmiah.

2. Perasaan tidak aman, terutama bila dikuatkan oleh inhibisi dalam tingkah laku dan proses penanggapan.

3. Ketelitian / kecermatan berlebihan yang bercorak kom-pulsif, tukang kritik, 
rigid, kaku, perfeksionis, mau serba sempurna, tanpa cacat, umumnya juga disertai penekanan pada skor dd atau de.

4. Bila FLR rendah dan tidak ditemukan gejala neurosa : skizofren paranoid.

5. Hasrat yang besar untuk mencapai sukses yang dimanifes-tasikan dalam produktivitas secara kuantitatif, dengan tujuan mencapai / menghasilkan sebanyak-banyaknya.

2. de : Jika skor de mendapat pekanan menunjukkan adanya

- ketakutan akan terlibat terlalu dalam terhadap sesuatu hal.

(sering muncul pada penderitapenderita kecemasan).

- kondisi anxiety pada orang introversif.

- ketelitian / kecermatan berlebihan sebagaimana dijumpai pada defens reaksi formasi dan isolasi yang kompulsif.

- kondisi skizofren paranoid. 
3. di :- Jika skor di didukung oleh FLR yang baik menunjukkan adanya kecemasan (yang sudah berjalan lama) didalam interpersonal relationship, kadangkadang disertai keasyikan dalam hubungan interpersonal, disertai minat cukup besar dalam pengaulan dengan sesama.

- Jika skor di didukung oleh FLR yang baik orang-orang yang memiliki bakat artistik, terutama mereka yang peka terhadap shading.

- Jika skor di disertai FLR yang rendah, dapat menunjukkan adanya kecenderungan patologis; yaitu paranoid.

- Jika skor di disertai FLR negatif : Patologis. Pada orang ski-zoid : mencirikan usaha melawan terhadap kemungkinan disintegrasi.

4. dr : - Jika skor dr bentuknya baik (FLR baik) dan hanya sedikit, berarti menggambarkan individu punya pemahaman yang baik, ada usaha untuk 
melihat persoalan dari sudut lain, perspektif, gampang dimengerti, cerdik dan pendekatan-pendekatan yang fleksibel.

- Jika skor dr bentuknya jelek (FLR rendah), menggambarkan

- Individu kurang bisa menggunakan rasionya.

- Punya sikap negatif terhadap hal-hal yang tidak jelas.

- Penekanan pada dr

1. Kemampuan mengamati dengan cepat dan fleksibel; bila FLR baik dengan pilihan lokasi yang layak dan seimbang, penyesuaian diri cukup baik, cerdas, dan serba ilmiah.

2. Kompulsif, mungkin neurotic, asyik dengan hal-hal detail.

3. Faktor yang mencirikan produktivitas dalam sistem kepribadian. 
4. Kondisi skizofren, terutama bila form-nya jelek.

5. Perkembangan psikoseksual terfiksasi pada fase anal, ka-dangkadang manifestasinya dalam bentuk ngomel-ngomel, rewel dan mencari-cari kesalahan.

6. Kontraindikasi terhadap kepribadian normal.

7. Jika FLR baik : artistik-orisinil.

8. Enggan menghadapi persoalan.

9. Kondisi senile.

3. S : Berkaitan dengan kecenderungan,

- Bersikap oposisi dalam bidang intelektualnya.

- Derajat negativism /keras kepala, skor $\mathrm{S}$ muncul dari mata dan mulut kucing pada kartu I.

$\rightarrow$ Apalagi jika penggunaan $\mathrm{S}$ ini merupakan respon keseluruhan dibanding jika $\mathrm{S}$ hanya merupakan bagian dari objek respon. 
$\rightarrow$ Penggunaan yang sedang-sedang saja/kadangkala, me-nunjukkan adanya

- Ego-strength.

- Kecenderungan suka menonjolkan diri.

$\rightarrow \quad$ skor $\mathrm{S}$ sedikit atau nol :

1. Orientasi passive-dependent, penyesuaian diri secara pasif dan banyak ditentukan pihak lain, patuh, tunduk dan mengalah.

2. Pasrah, tawakal

$\rightarrow$ Penekanan pada respon S (dengan

Space besar)

1. Suka membantah, oposisional, pribadi maladjusted yg. sukar menyesuaikan diri.

2. Pribadi yang agresif, kadangkadang juga anti sosial. 
3. Menonjolkan diri, mementingkan diri sendiri, tekun, bertekad, kompetitif.

4. Sangat individualitas, bekerja sendiri untuk mencukupi / menyelesaikan urusannya sendiri

5. Bila FLR baik : energik, penuh semangat, giat, kritis, orientasi non-suggestible, cara penyesuaian diri tidak karena atau ditentukan oleh pengaruh luar.

7. Kondisi psikosomatik, terutama bila juga terdapat pe-nekanan pada respon $\mathrm{S}$.

8. Anxiety rendah.

9. Hubungan dengan lingkungan kurang baik.

$\rightarrow$ Penekanan pada respon S (dengan

Space kecil)

1. Pada umumnya dapat ditafsirkan sama untuk respon S, terutama yang menyangkut sikap oposisional. 
2. Psychosomatic reactions, terutama bila juga disertai penekanan pada respon $\mathrm{S}$.

\section{B. Skor Determinant}

Umumnya, skor-skor determinant ini berkaitan dangan aspek-aspek emosional dari kepribadian seseorang.

\section{a. HIPOTESA skor $F$}

- Pada umumnya, menunjukkan derajat kontrol intelektual yang ada pada individu.

- Selain itu juga dapat merupakan petunjuk adanya ego-strength.

a.1. Hipotesa F\% :

* Besar kecilnya F\% mencirikan besar kecilnya kontrol yang men-cerminkan kemampuan menangani situasi tanpa terlibat secara emosional.

- Makin besar F\% makin besar pula kemampuannya untuk bersikap impersonal, tidak sentimenan, dan tidak mengada-ada, matter of fact, sebagaimana adanya, obyektif. 
* Dengan disertai FLR yang baik (adekuat) menggambarkan "derajat kontrol diri" individu, yaitu :

- makin tinggi F\% menggambarkan individu yang makin mampu menghadapi semua orang dan tidak berbelit-belit.

* Normal range F\%, yaitu $20-50 \%$.

* F\% tinggi $(50$ - $80 \%)$ tanpa ada banyak gerakan, shading dan warna :

- Rigiditas dan constriction, kaku, dan menyempit, respon kaku.

* F\% tinggi $(50-80 \%)$ ada banyak gerakan, shading dan warna :

- individu yang "rich-personality" (= kepribadian yang fleksibel / luwes), dan manakala perlu juga dapat bersikap obyektif, sebagai-mana adanya, tidak mengada-ada, matter of fact.

* F\% rendah $(<20 \%)$ yaitu kurang menekankan $\mathrm{F}$, tetapi bisa memberi respon $\mathrm{M}, \mathrm{Fc}$ dan $\mathrm{FC}$ dalam jumlah cukup, menunjukkan

- kurang bisa mempertahankan / memelihara hubungan baik, tetapi masih bisa bertindak 
spontan, kreatif, sangat memperhatikan (perasaan) orang lain, dan bisa sensitif terhadap orang lain.

* Jika F\% rendah tanpa disertai faktor pengontrol lainnya, me-nunjukkan :

- kontrol diri individu kurang baik, terlalu mementingkan pribadi-nya.

* Bila F\% > 80\%, indikasi : patologis.

a. Bila disertai dengan bentuk yang adekuat (FLR baik), me-nunjukkan :

- Derajat constriction tinggi, artinya : Terlalu menarik diri.

- Kurang spontan.

- Seringkali muncul pada penderita depresi. Penderita ini juga sangat kompulsif.

b. Bila bentuknya sedang-sedang saja (FLR sedang), mewakili :

- Individu yang kurang mampu membedakan mana yang baik dan buruk, sehingga kurang mampu merespon segala sesuatu di luar dirinya.

a.2. Kualitas Bentuk : 
Berkaitan dengan ketepatan persepsi subyek terhadap obyek / konsep gambar yang disajikan.

* Ada 3 level / taraf ketepatan bentuk :

1. F + : Bila bentuknya lebih baik daripada respon-respon $\mathrm{P}$ atau yang mendekati $\mathrm{P}(\rightarrow \mathrm{P})$

2. F : Bila bentuknya P (populer) atau yang mendekati $\mathrm{P}$.

3. F- : Bila bentuk tidak adekuat / tepat.

* Makin tinggi taraf ketepatan bentuknya, menunjukan :

- Individu yang makin terlibat/cenderung suka pada "exactness" / ketepatan / kepastian / kecermatan, juga suka pada situasi-situasi nyata (senang yang realistis).

- Biasanya individu seperti ini sangat intelejen / pandai, sangat kompulsif, atau intelejen dan kompulsif.

* Bila tarafnya F (rata-rata) atau (F-), indikasinya : 
- Individu tidak seperti pada F+, artinya : tidak sepandai orang yang mampu menghasilkan respon $\mathrm{F}+$, dan kontrol emosinya kurang baik dibanding pada individu dengan $\mathrm{F}+$.

b. HIPOTESA skor Movement (M, FM, Fm, mF, m) * Umumnya, berkaitan dengan sikap dan perasaan individu terhadap pengalaman inner-reality nya, yaitu :

Terhadap self-concept nya, keteganganketegangannya, dan konflik - konflik yang muncul berkaitan dengan penerimaan lingkungan terhadap dirinya, fantasifantasinya, dan dorongan-dorongan dari dalam dirinya.

b.1. skor M :

* Munculnya jawaban $M$ itu seringkali karena : 
1. Subyek memproyeksikan seolah-olah ada gerakan pada gam-bar statis/ink-blot Ro yang disajikan. ini menggambarkan :

- proses imajinasi yang secara bebas bisa dimunculkan testee.

2. Subyek mempersepsi M pada gambargambar yang tampak seperti manusia, atau pada bagian-bagian yang menyertai manusia. ini mewakili :

- kemampuan empati subyek terhadap orang lain.

3. M yang dipersepsi subyek dalam bentuk yang jelas, berarti :

a. Subyek punya taraf ego-functioning yang baik sekali, artinya:

- selain subyek bisa menerima keadaan dirinya, dorongan- dorongan, fantasifantasi, dalam waktu yang sama subyek bisa menciptakan relasi yang baik dengan orang lain.

b. Kemungkinan subyek orang yang jelas.

c. Kemungkinan subyek berkepribadian baik. 


\section{d. Cenderung kreatif.}

* Interpretasi ini semua berlaku bila jumlah M $\geq 3$.

Orang dewasa yang well-adjusted intelligent, diharapkan mampu menghasilkan sedikitnya tiga konsep jawaban yang bisa diskor $\mathrm{M}$

* Bila jawaban M disertai FLR minus ( - ) berarti :

- Ego-organisasinya kurang baik, taraf egofunctioningnya rendah.

* Jumlah M di atas rata-rata :

1. Introversive, bijak, berteggang rasa, menahan diri, namun hal demikian tidak selalu benar pada $\mathrm{S}$ dewasa.

2. Intelegensi dan prestasi studi di atas ratarata.

3. Kreatif, ada kemampuan menciptakan sesuatu, memiliki po-tensi kreatif.

4. Kaya akan fantasi dan imajinasi.

5. Ada insight, dapat memahami dirinya dan masalah-masalah yang dihadapi dirinya. 
6. Fungsi ego baik, self-orientation positif dan konsisten.

Pada terapi : perasaan mudah dilukai dan rapuh minim.

8. Kemampuan merencanakan baik.

9. Bebas dalam mengekspresikan dirinya, kemampuan berbahasa baik.

10. Dapat mentolerir frustasi, mampu menaggung rasa kecewa, boleh jadi berhubungan dengan orientasi $\mathrm{S}$ yang tidak senantiasa merasa diburu waktu.

11. Sensory isolation.

12. Mild intoxication, keracunan ringan, suka mabuk-mabukan.

* M dengan FLR rata-rata (Kualitas M ratarata)

1. Tingkah laku berpijak pada realityprinciple.

2. Self-acceptance dan fungsi ego cukup baik.

3. Kemampuan empati cukup baik.

* Respon M fleksor 
1. Kecenderungan ke arah pasif, dependen, tergantung dan sub-missive, tunduk patuh.

2. Tidak adekuat.

3. Sikap pasrah, pesimis, putus asa.

4. Prognosa jelek.

* Respon M ekstensor

1. S yang aktif, berusaha keras, percaya pada diri sendiri.

2. Prognosa baik, dalam psikoterapi banyak beroleh kemajuan.

b.2. Skor FM :

* Pada dewasa normal rata-rata : 4,5 (mean)

* Skor FM menggambarkan :

- Kekurangmatangan

- Kurang menyadari dirinya,

- Kadang-kadang menggambarkan kekurang-mampuan subyek menerima sebagai dorongan-dorongan dasarnya.

Jadi, FM sebenarnya mencerminkan kuatnya dorongan-dorongan impulsif dan dipihak lain juga mencirikan sampai berapa jauh seseorang bisa menerima kehadiran impuls$40 \mid \mathrm{P}$ a g e 
impuls yang menuntut pemuasan segera dan karenanya perlu dikontrol.

* Dibandingkan dengan M, FM mencirikan : impuls-impuls dasar yang belum matang, belum diolah, dan kadang-kadang juga tidak disukai kemunculannya.

* Bila subyek gagal merespon FM, atau FM muncul sebagai skor additional, berarti :

- Subyek ini cenderung merepress/menekan dorongan-dorongan yang lebih primitive, yang kemunculan impuls tersebut tidak dikehendaki atau tidak disukai.

Seringkali dorongan-dorongan tersebut, yang tercetus dalam FM, sulit untuk dikenali. Hal ini bisa dibantu dengan menganalisa content dari jawaban FM. Jumlah FM di atas rata-rata :

1. Spontan, impuls emosional relatif tak terkontrol.

2. Penampilan impuls yang menuntut pemuasan segera. 
3. Pada $\mathrm{S}$ dewasa : Pribadi immature, maladjusting, penyesuaian diri kurang, dan regressi.

4. Hambatan motorik atau tidak mampu dimobilisir.

5. Keadaan anxienty.

6. Pada $\mathrm{S}$ dengan IQ tinggi : Hubungan dengan sesama terbatas tapi cukup signifikan.

7. Sensory isolation.

* Jumlah FM rata-rata

1. Sadar akan adanya impuls-impuls moderat yang menuntut pemuasan segera.

2. Mencirikan kehadiran natural dan unaculturated drive dengan kekuatan normal, dorongan-dorongan yang belum diolah/ disesuaikan dengan kebiasaan akan tetapi tetap dalam batas-batas wajar yang tampil dengan kekuatan normal.

3. Intelegensi rata-rata.

* Jumlah FM di bawah rata-rata 
1. Basic needs dan emosi di-repress atau disupress.

2. Pada $\mathrm{S}$ anak-anak : Kurang hidup, kurang bersemangat, tidak riang gembira, diminished animation.

3. Pada S usia lanjut : Kondisi senile.

* Kualitas FM di atas rata-rata

1. Bila ditemukan pada $S$ mental retarded (=terbelakang), berarti IQ tergolong tinggi pada kelompok tersebut.

2. Pada $\mathrm{S}$ anak-anak : IQ tinggi.

* Kualitas FM di bawah normal

1. Reality testing jelek dan pikiran yang tidak realistik se-bagaimana ditemukan pada skizofren paranoid.

2. Dalam keadaan stress dan frustasi, pengendalian drives dan impuls menjadi ngawur atau tidak adekuat, terutama ditemukan pada skizofren paranoid.

* Kualitas FM normal

- Kualitas normal mengendalikan impulsimpuls dan drive-drive.

b.3. Skor m (Fm, mF, m): 
* Bila $m>1$ atau 2, umumnya menunjukkan :

- adanya tension / ketegangan dan konflik yang dialami individu.

Jadi bisa menggambarkan :

- Inner atau outer forces yang tidak bisa dikontrol subyek, sehingga mengancam ego-nya.

* Absennya skor m, merupakan tanda-tanda yang membahayakan.

* Skor m, yang sering keluar menunjukkan :

- Kemampuan penyesuaian diri yang baik sekali.

* Munculnya respon Fm, mF, m :

- pada umumnya mencirikan adanya tension dan konflik.

- mencirikan bahwa orang yang bersangkutan sadar akan kekuatankekuatan tak dikehendaki yang mengancam sistem kepribadian.

* Dewasa normal $(\mathrm{Fm}+\mathrm{mF}+\mathrm{m})=1,0$ (mean)

* Bila skor m (Fm, mF, m) muncul lebih dari satu atau dua, mencirikan adanya kekuatan- 
kekuatan dari dalam diri atau dari luar yang tidak terkontrol, tak terkendali, tak terkuasai dan karenanya dirasakan sebagai mengancam ego.

* Jumlah $\mathrm{Fm}+\mathrm{mF}+\mathrm{m}$ di atas rata-rata

1. Tension, stress dan /atau anxiety.

2. Konflik dan tension karena adanya impuls yang penyalurannya dihambat, terutama konflik dalam hubungan dengan tujuan jangka panjang.

3. Perasaan bahwa ada kekuatan-kekuatan yang mengancam ego dan berbahaya bagi penyesuaian diri dan organisasi kepribadian secara keseluruhan.

4. Perasaan tidak berdaya dalam menghadapi kekuatan-kekuatan da-ri lingkungannya yang tak bisa dikontrol.

5. Defens represif yang signifikan.

6. Tendensi obsessive compulsive.

7. Pribadi non psikotik, merupakan kontra indikasi dari psikosis.

8. Ditemukan pada anak-anak yang mengalami gangguan emosi-onal. 
9. Latent homoseksual mendekati homoseksual panic.

10. Pada anak-anak dan dewasa : agresi.

11. Sensory isolation.

* Jumlah $\mathrm{Fm}+\mathrm{mF}+\mathrm{m}$ rata-rata

- Mencirikan usaha S cukup memadai sehingga bisa me-nangguhkan kehidupan impuls-nya dan dihadapkan pada realitas.

- Penyesuaian diri dalam pekerjaan cukup baik.

* Kualitas Fm, mF, m menyolok rendah

- Lebih banyak ditemukan pada skizofren paranoid daripada pada orang-orang neurotik.

\section{c. HIPOTESA Skor Shading}

\section{c.1. Respon SURFACE atau TEKSTUR : Fc, cF, c}

* Pada umumnya, menunjukkan : cara-cara

seseorang me-“menej” / mengelola

kebutuhan-kebutuhan dasar akan :

- Affection / afeksi

- Belonging / menjadi bagian dari suatu kelompok 
- Memperoleh kepuasan dari dari kontak / hubungan sosialnya. (kebutuhan ini ada pada semua orang).

- Adanya keinginan untuk bisa memuaskan kebutuhan tersebut, dan kenyataan akan adanya kesulitan yang dialami individu didalam mengemudi / menangani kebutuhan tersebut.

* Berbagai skor yang lahir karena shading, pada umumnya meng-gambarkan :

- Bagaimana seseorang mengelola needsnya akan affeksi, kebutuhan untuk diterima dan untuk merasa sebagai bagian dari lingkungannya, untuk menyatakan perasaan-perasaannya, untuk menciptakan hubungan dengan sesama yang menyenangkan (Pada dasarnya setiap orang memiliki need-need yang elementer tersebut) .

- Antisipasi (=harapan) pemuasan needneed tsb dan sampai berapa jauh kesulitan yang dihadapi seseorang dalam menangani need-need tadi tercermin 
pada bermacam-macam skor shading yang tampil.

- Semua tercermin dalam skor-skor shading yang dimunculkan individu

* Skor-skor Fc, cF dan c berkaitan dengan :

kesadaran subyek bahwa dirinya memiliki need for affection (kebutuhan afeksi) dan dependency (ketergantungan) dalam dirinya. Dan sikapnya ditentukan oleh atau berorientasi pada sikap orang lain.

* Pemunculan respon-respon texture ini $(\mathrm{Fc}$, $\mathrm{cF}, \mathrm{c})$ dapat mengungkap :

a. Sensitivitas individu terhadap nuansanuansa / hal-hal yang lebih halus di lingkungan subyektif dan obyektifnya.

b. Adanya perhatian individu terhadap seberapa besar afeksi dan atensi yang bisa diterima dari dunia sekitarnya. Individu harap-harap cemas menimbangnimbang berapa banyak kiranya affek dan perhatian yang bisa diharapkan dari relasi dengan lingkungannya. 
* Seberapa jauh kepekaan perasaan-perasaan ini dapat kita per-hatikan dari pemanfaatan shading sebagai respon tekstur : ekspresi / peryataan paling kasar dinyatakan oleh skor c dan yang paling lembut dinyatakan oleh skor Fc.

\section{c.1.1. Skor Fc}

* Dewasa normal : $\mathrm{Fc}=2,6 ;(\mathrm{cF}+\mathrm{c})=0,4$ (mean)

* Respon Fc, menunjukkan :

adanya kesadaran dan penerimaan individu terhadap kebutuhan afeksinya sendiri, disamping juga dapat memahami need-need dan perasaan orang lain.

$\rightarrow$ Kebutuhan akan afeksi ini (need for affection) biasanya muncul dalam bentuk :

- keinginan

memperoleh penghargaan dan respon (umpan b g dari orang lain.

* Pada mulanya, kebutuhan akan kontak sosial tersebut bersifat infantil ; tetapi 
pada masa selanjutnya harus bisa dikontrol dan diperhalus menjadi bentuk kebutuhan yang lebih bisa diterima.

Hal ini bisa terlaksana bila kebutuhan dasar akan rasa aman (need for security) sudah cukup terpuaskan.

Oleh karena itu :

* Bila jumlah respon Fc optimal bisa menunjukkan bahwa :

Individu punya :

* Tactfulness (kebijaksanaan)

* Awareness (kesadaran diri)

* Sensitivity (sensitivitas)

* Bila terlalu menekankan jawaban Fc, berarti :

- Individu terlalu tergantung pada orang lain.

* Bila kurang memberi jawaban Fc atau nol, yang disebabkan oleh :

a. Jawaban shading yang dihindari :

- Individu kurang bisa menerima adanya kebutuhan afeksi yang sebenarnya ada pada dirinya. 
b. Kurang sensitif terhadap jawaban shading :

- Hanya sedikit kebutuhan akan afeksi yang ada pada subyek.

* Jumlah Respon Fc di atas rata-rata

1. Anxiety, terutama bila dikuatkan oleh ciri-ciri lain yang menandakan anxiety. (berlaku untuk S anak-anak dan dewasa).

2. Need akan affeksi sangat menonjol yang oleh karenanya menjadi tergantung pada affek yang bisa diharapkan dari orang lain atau butuh diperhatikan dan mendapat respon dari orang lain, atau keduaduanya sekaligus.

3. Bila Fc yang keluar menyolok banyak, corak affek kekanakkanakan yang terselubung bersamaan dengan hasrat dibelai / kontak yang infantil, akan tetapi 
relatif masih tetap bisa dikontrol secara adekuat.

4. Kemungkinan neurosis.

5. Pada $\mathrm{S}$ anak-anak : gangguan emosional.

6. Pada S mentally retarded : high grade familial mental rentardation.

* Jumlah respon Fc di bawah rata-rata

1. Kurang menyadari, merepress dan / atau menyangkal need akan affeksi.

2. Need akan affeksi tidak / kurang berkembang, maladjus-ting egocentric condition, orang egosentris yang kurang bisa menyesuaikan diri, narsistis.

3. Anxious person, gelisah, khawatir, cemas.

4. Pasien peptic ulcer.

5. Kemungkinan psikosa.

* Jumlah respon Fc rata-rata

1. Hubungan interpersonal cukup baik, cukup sensitif terha-dap need orang lain, empati cukup. 
2. Secara wajar menyadari dan bisa menerima kehadiran need akan affeksi, termasuk hasrat untuk diiyakan, untuk dibenarkan dalam bentuk yang telah dihaluskan/matang, hasrat untuk memperoleh respon, untuk diterima oleh dan menjadi bagian dari sesamanya.

3. Needs akan rasa aman terpenuhi.

4. Kontrol terhadap moods (=suasana hati) memadai, bijak, bertenggang rasa.

* Kualitas respon Fc di atas rata-rata

1. Needs akan affeksi berkembang dengan baik, secara sehat $\mathrm{S}$ menyadari dan dapat menerima needs akan affeksi.

(Lihat juga jumlah respon Fc ratarata).

* Kualitas Respon Fc di bawah ratarata 
1. Needs akan affeksi yang kuat tidak terintegrasi baik dalam sistem kepribadian.

2. Emosi dangkal yang sampai batas tertentu dirasakan sebagai menggangu dalam penyesuaian diri.

c.1.2. Respon $\mathrm{cF}$, juga menggambarkan adanya :

a. Kebutuhan akan keterdekatan/keakraban yang immature, selalu tergantung pada orang lain.

b. Kadang-kadang menggambarkan adanya kebutuhan akan rasa nikmat dari kontak seksual.

* Jumlah respon $\mathrm{cF}$ di rata-rata

1. Immature.

2. Needs akan relasi dengan sesama yang didasari oleh depen-dancy.

3. Anxiety yang kuat berhubungan dengan needs akan affeksi yang dialami pada masa kanak-kanak. 
4. Needs untuk menikmati hubungan seksual dalam bentuk yang mental, kasar.

5. Perasaan inferior.

6. Kontrol terhadap suasana hati kurang.

* Jumlah respon $\mathrm{cF}$ di bawah rata-rata atau nol

1. Kondisi anxiety.

2. Needs akan affeksi dalam bentuk yang mentah / kasar, umumnya bercorak badani yang senantiasa menuntut untuk dipuaskan.

c.1.3. Respon c, menunjukkan :

- adanya kebutuhan afeksi yang sifatnya infantil, tak ter-differensiasi dan kasar, terutama yang dinyatakan dalam berbagai bentuk kontak fisik.

\section{c.2. Respon VISTA atau DEPTH : FK, KF, K}

* Skor Fk, kF dan k bisa menunjukkan adanya : 
- Kecemasan terhadap kebutuhan afeksinya, yang coba ditutupi de-ngan cara-cara yang logis / intelektual.

* Mean dewasa normal : $\mathrm{FK}=0,5 ;(\mathrm{KF}+\mathrm{K})=$ 0,2 ; batas kritis $\mathrm{K}>3$

* Individu yang lebih cenderung memberi jawaban Fk daripada $\mathrm{kF}$ atau $\mathrm{k}$ :

- Biasanya lebih mampu mengontrol kecemasan dengan cara-cara yang logis / intelektual.

* Didalam memberi jawaban $\mathrm{k}$ ini subyek menggunakan aspek shading untuk memberi kesan 3 dimensi pada gambar Ro, tetapi hasilnya hanya tampak dalam bentuk gambar 2 dimensi, misal :

- gambar sinar X dan gambar peta, yang terlihat dalam bentuk 2 dimensi.

Meskipun secara logika bisa ditangkap adanya aspek 3 dimensi dalam jawaban yang diberikan.

\section{c.2.1. Skor FK :}

* Bila seseorang memberi jawaban FK, menunjukkan kalau orang tersebut 
melihat obyek gambar Ro seolah-olah punya aspek kedalaman dan perspektif (3 dimensi) seperti halnya dengan benda-benda / hal-hal yang pernah dikenali / akrab dengannya.

* FK menunjukkan bahwa :

Individu berusaha untuk memahami dan menghadapi dan mentolerir kecemasan dalam dirinya.

* Bila FK muncul dalam jumlah cukup banyak :

berkaitan dengan adanya penyesuaian diri yang baik pada diri individu tersebut, terutama didalam proses psikoterapi.

* bila FK nol :

tidak berarti / tidak punya pengaruh secara signifikan.

c.2.2. Skor $\mathrm{KF}$ dan $\mathrm{K}$ (dalam rasio $\mathrm{KF}+\mathrm{K}$;

batas kritis $\mathrm{K}>3$ ):

* Adanya respon $\mathrm{KF}$ dan $\mathrm{K}$ menunjukkan 
subyek berusaha menggunakan shading untuk memberi kesan / efek menyebar, tidak terstruktur, tetapi bersifat 3 dimensi terhadap gambar Ro.

* Skor KF dan K berkaitan dengan : adanya kecemasan yang muncul karena mengalami kegagalan dialam usaha untuk memperoleh pemuasan terhadap kebutuhan efeksinya ; dan individu tidak mampu menemukan defens yang tepat guna menutupi kegagalan tersebut.

* Dengan kata lain, skor KF dan K mewakili :

adanya kecemasan yang disebabkan oleh kegagalan didalam memperoleh pemuasan terhadap kebu-tuhan afeksinya.

* Batas kritisnya : $\mathrm{K}>3$, karena lazimnya setiap orang mengalami anxiety berhubungan dengan need akan afeksi. 
Munculnya beberapa skor KF atau $\mathrm{K}$ bisa dianggap sebagai hal yang biasa, tapi jika ditemukan skor $\mathrm{K}>3$ :

- kecemasan berhubungan dengan need akan affeksi yang

"lebih dari biasa ".

* Jumlah respon vista di atas rata-rata

1. Anxiety dan upaya untuk mengatasi anxiety yang ber-sumber pada affek secara obyektif dengan introspeksi dan tidak memihak.

2. Mampu memahami diri (=introspeksi) bersama-sama dengan memahami lingkungan sosialnya.

3. Negativism, perasaan tidak aman, insecure dan inferior.

4. Ada insight bersama-sama dengan peringanan anxiety yang dengan demikian berarti $\mathrm{S}$ beroleh manfaat dari dari insight tadi, motiv yang berguna. 
5. Need yang besar untuk berprestasi dalam bidang intelektual atau arstistik.

6. Intelegensi diatas rata-rata.

7. Unhappy worriers, orang yang merasa tidak berbahagia karena senantiasa dirundung kesusahan / kecemasan.

8. Pada S anak-anak : epilepsi.

9. Bila FK yang keluar banyak, berarti ketidakmampuan untuk beranjak keluar dari orientasi yang berpangkal pada diri sendiri.

* Jumlah respon vista di bawah rata-rata atau nol

1. Anxiety yang bersumber pada affek rendah.

2. Tidak atau hanya sedikit menyadari akan anxiety yang bersumber pada affek karena sistem defens yang efektif.

3. Kondisi brain damage. 
4. Suicidal tendencies, kecenderungan bunuh diri.

* Jumlah respon vista rata-rata

1. Penyesuaian diri baik.

2. Mampu mentolelir anxiety.

3. Usaha untuk mengatasi anxiety yang bersumber pada affek secara obyektif dengan introspeksi.

* Kualitas respon vista di atas rata-rata

Healty self appraisal, penilaian diri yang sehat.

* Bila secara umum keseluruhan protokol memberikan gam-baran yang tidak mengecewakan berarti momentarily inferiority feeling yang dimanfaatkan secara konstruktif oleh ego.

* Kualitas respon vista di bawah rata-rata

1. Sikap introspeksi yang membuka kemungkinan untuk bisa keluar dari inner problem.

2. Anxiety. 
* Jumlah respon $\mathrm{KF}$ dan $\mathrm{K}$ di atas ratarata

1. Anxiety, terutama free-floating anxiety atau "general type".

2. Anxiety yang mencerminkan adanya frustasi berhubu-ngan dengan tuntutan pemenuhan affeksi.

3. Depresi sampai ke batas sikap pasrah, kehilangan gairah dan apati.

4. Pada $S$ anak-anak : gangguan emosional.

* Jumlah respon $\mathrm{KF}$ dan $\mathrm{K}$ sedikit atau nol

Tidak nampak gejala adanya anxiety.

* Jumlah respon KF rata-rata

Kepribadian normal.

* Jumlah respon KF rata-rata

Kepribadian normal.

III.c. Respon TIGA DIMENSI yang ditangkap pada bidang DUA DIMENSI : Fk, kF, k

* Respon Fk, kF, k terjadi karena : 
pemanfaatan shading untuk sesuatu yang dimaksudkan tiga dimensi akan tetapi usaha untuk menjangkau maksud tersebut hanya sampai pada konsep dua dimensi. "Foto rontgent" \& "Topographical map " adalah sesuatu yang dua dimensi, datar, walaupun secara intelektual baik foto rontgent maupun topografis "dibaca" sebagai sesuatu yang tiga dimensi.

Dengan demikian Fk, kF, dan k agaknya mencirikan anxiety yang berhubungan dengan need akan affeksi yang oleh $\mathrm{S}$ dicoba diatasi dengan intelektualisasi.

* Fk lebih banyak muncul daripada kF atau k atau $(\mathrm{kF}+\mathrm{k})$ :

berarti sampai batas tertentu $\mathrm{S}$ dapat mengontrol anxiety dengan intelektual.

* Jumlah respon $\mathrm{Fk}, \mathrm{kF}$, dan $\mathrm{k}$ di atas rata-rata

1. Fk dihubungkan dengan pseudo insight : pada $\mathrm{S}$ yang cukup intelejen mencirikan usaha yang sia-sia untuk mengatasi anxiety dengan defens intelektualisasi atau rasionalisasi. 
2. Fk dihubungkan dengan anxiety yang bersumber pada affek :

kadang-kadang disertai outer-control yang memadai, namun tetap dirasakan sebagai menggangu disamping juga merupakan gangguan dalam penyesuaian diri.

3. Fk dan $\mathrm{kF}$ dihubungkan dengan "tipe eksekutif" :

dimana kerja keras yang bercorak kompulsif (=dorongan paksa) mungkin sebenarnya merupakan merupakan defens terhadap anxiety.

4. $\mathrm{kF}$ dan $\mathrm{k}$ mencirikan :

free-floating anxiety yang dengan bermacam upaya dicoba untuk diatasi dengan mengembangkan defens yang sekiranya memadai.

* Jumlah respon $\mathrm{Fk}, \mathrm{kF}$ dan $\mathrm{k}$ rata-rata

1. Tanpa anxiety yang bersumber pada affek sebagaimana lazim dijumpai pada S normal.

* Jumlah respon k rata-rata 
1. Munculnya respon k bisa diinterpretasikan sama seperti munculnya respon $\mathrm{K}$.

\section{d. HIPOTESA skor COLOR}

- Pada umumnya, skor warna ini berkaitan dengan responsivitas (=kemampuan dari bentuk respon) individu terhadap stimulus dari lingkungan luarnya. Stimulus tersebut, berasal dari adanya interpersonal-relationship.

Respon warna menggambarkan bagaimana individu bereaksi terhadap pengaruh emosional yang mungkin timbul akibat relationship individu dengan orang lain.

* Lima kartu Rorschach berwarna bisa mempengaruhi emosi individu yang melihat.

- Dengan memberikan 5 kartu berwarna kita bisa melihat bagaimana reaksi subyek terhadap kartu-kartu tersebut. Dari sini kita bisa memperoleh informasi tentang bagaimana aspek emosi subyek terlibat.

* Reaksi terhadap warna dapat ditafsirkan sebagai petunjuk bagaimana seseorang bereaksi terhadap 
dampak emosional dalam hubungan dengan sesamanya.

III.d.1. Skor Warna Chromatic : FC ; CF ; C mean dewasa normal $; \mathrm{FC}=2,1 ; \mathrm{CF}=1,8 ; \mathrm{C}=$ 0,2

d.1. Skor FC :

* Respon-respon FC menunjukkan :

Kesiapan tetapi tetap terkontrol didalam merespon hal-hal yang mempengaruhi emosional.

- Kemampuan ini / reaktivitas ini menunjukkan bahwa :

Individu dapat menghadapi situasi-situasi yang mempengaruhi emosinya dengan cara yang tepat, sehingga individu dapat bergaul baik dan lancar dengan orang lain.

- Skor FC ini merupakan informasi tentang adanya :

Kemampuan penyesuaian diri yang baik pada individu yang bersangkutan.

- Dengan kata lain, subyek bukan saja peka tetapi juga responsif terhadap tantangan emosional, dan mampu mengendalikan $66 \mid \mathrm{P}$ a g e 
responnya. Subyek mampu bereaksi dengan cara yang tepat, yang pantas, terhadap situasi dengan kandungan suasana emosional, dan karena itu ia dapat bergaul secara luwes dengan sesamanya.

- Skor FC adalah salah satu diantara skor yang paling bisa dipercaya yang mencirikan penyesuaian diri yang baik.

* Jumlah respon FC di atas rata-rata

1. Kesanggupan melayani tantangan emosional dengan cara yang anggun, ego berfungsi baik.

2. Dependance on other people, tergantung pada orang lain.

3. Pada subyek anak-anak : over-training, terlalu banyak diatur, spontanitas dihambat supaya bisa memenuhi tuntutan.

4. Pada $\mathrm{S}$ dewasa dan anak-anak dengan gejala neurotik : Lebih kearah obsessivecompulsive dibandingkan dengan $\mathrm{S}$ yang anxiety-reaction.

5. Mencirikan usaha untuk berhubungan dengan orang lain. 
6. Tahan belajar di bawah stress.

7. Kontra-indikasi dari skizofren.

* Jumlah respon FC di bawah rata-rata

1. Penyesuaian affek tidak baik, kontrol emosi tidak memadai.

2. Hubungan interpersonal tidak baik.

3. Kondisi neurotic-anxiety.

4. Pada subyek anak-anak FC rendah bisa berarti normal atau bisa juga mencerminkan anxiety.

5. S wanita : Konversi-hysteria.

6. Kemungkinan kondisi skizofren.

7. Mild intoxication, mabuk-mabuk ringan.

8. Pada S usia lanjut : kondisi senile.

* Jumlah respon FC rata-rata

1. Dapat mengontrol dampak emosional tanpa kehilangan fleksi-bilitas atau responsibilitas.

2. Hubungan interpersonal cukup memuaskan, penyesuaian diri dengan lingkungan sosial cukup baik. 
3. Penyesuaian diri secara umum dapat dikatakan sehat dan kon-sisten : sebegitu jauh interpretasi demikian dapat dipercaya.

* Kualitas respon FC di atas rata-rata $(\mathrm{FC}+)$

1. Penyesuaian diri baik.

* Kualitas respon FC di bawah rata-rata (FC -)

1. Kontrol emosi menjadi tak terkendali.

2. Usaha yang gagal untuk mengontrol respon emosi.

3. Affek lebih kuat dari intelek.

* Respon $\mathrm{F} \leftrightarrow \mathrm{C}$, mencerminkan adanya :

Ketegangan tertentu yang dialami subyek didalam social-relation.

(Lihat juga $\mathrm{C} \leftrightarrow \mathrm{F}$ )

* Respon F/C, menunjukkan bahwa :

Individu hanya merespon secara dangkal saja, tanpa melibatkan perasaannya.

Jadi, tergantung situasi saja bila menghadapi hal-hal yang bisa mempengaruhi emosinya.

* Respon FC- , biasanya menunjukkan adanya 
Gangguan (kehilangan kontrol) didalam reality-testing pada kontak-kontak yang melibatkan emosinya.

\section{d.2. Skor CF :}

* Respon-respon CF menggambarkan bahwa :

Reaksi subyek terhadap rangsanganrangsangan sosial kurang terkontrol tetapi masih tepat dan bersungguh-sungguh, sehingga bisa muncul reaksi-reaksi yang bersifat impulsif / menuruti kata hatinya.

Jadi, skor CF menunjukkan adanya :

- Kontrol emosi yang kurang tepat, yaitu : cenderung bertindak spontan tetapi kurang tepat / negatif.

* Kelahiran skor CF terjadi karena S tidak mencoba atau tidak ada usaha untuk mengintegrasikan warna dengan bentuk yang defenitif untuk bahan dari konsep respon yang diberikan.

Oleh karena itu, respon CF mencirikan :

- reaksi terhadap rangsang sosial yang agak kurang terkontrol namun demikian 
reaksinya bisa dibilang tepat, pantas, dan tulus, asli, tidak dipoles. Dalam hal demikian rangsang tadi telah mempengaruhi $\mathrm{S}$ demikian rupa sehingga ia memberikan reaksi secara spontan, impulsif. Oleh karena itu skor CF dapat ditinjau dari dua segi.

a. Segi yang positif, yaitu yang mencirikan bahwa $\mathrm{S}$ mem-berikan reaksi yang spontan, tidak dibuat-buat, tidak dipoles.

b. Segi yang negatif, yaitu yang mencirikan bahwa reaksi $\mathrm{S}$ tidak terkontrol secara adekuat.

* Jumlah respon CF di atas rata-rata

1. Impulsif, kecenderungan melampiaskan respon emosional.

2. Pada $\mathrm{S}$ dewasa : Emosi immature, tidak dapat menyesuaikan diri secara emosional.

3. Kecenderungan menyerang.

4. Pada S anak-anak dan dewasa : anxiety.

5. Hysteria.

6. Pada S feebleminded : Sangat sugestibel, sangat mudah di-pengaruhi dan karenanya menjadi potensiil sebagai delinkuen. 
7. Menjadi sangat sensitif dan gampang marah.

* Jumlah respon CF di bawah rata-rata

1. Kurang spontan yang juga bisa berarti cenderung penyesuaian diri kurang.

2. Mungkin kontrol emosi terlalu ketat, mungkin pula responsi-vitas emosional banyak dikurangi.

3. Kemungkinan cenderung bunuh diri.

* Jumlah respon CF rata-rata

1. Spontanitas yang wajar.

2. Dengan hanya sedikit CF yang muncul : kontrol emosi agak le-mah, namun responsivitas emosional bisa dinilai tepat.

3. Pada protokol yang mengesankan psikopatologi : kemungkinan skizofren, dibedakan dari kemungkinan neurosis dan character-disorder.

* Kualitas respon CF rata-rata dan di atas ratarata

Sama seperti jumlah respon CF rata-rata.

* Kualitas respon CF di bawah rata-rata

1. Kontrol respon emosi tak terkendali. 
2. Tingkah laku impulsif yang irrasional, kurang pertimbangan atau terlalu emosional.

3. Kurang usaha atau tidak memiliki cukup motif untuk berdaya upaya mengendalikan emosi.

4. Skizofren paranoid.

5. Hypomania

* Respon $\mathrm{C} \leftrightarrow \mathrm{F}$ (seperti juga $\mathrm{F} \leftrightarrow \mathrm{C}$ ) menggambarkan :

Individu berusaha melibatkan dirinya secara emosional, akan tetapi ia tak mampu berbuat demikian, bahkan ditahan-tahan.

* Respon C/F mengungkapkan :

Adanya reaksi subyek yang sifatnya impersonal dan superficial (hanya dangkal saja), tetapi reaksinya di luar maunya, di luar control, mungkin karena $\mathrm{S}$ sudah lebih dulu tenggelam dalam persoalannya sendiri.

\section{d.3 Skor C:}

* Kategori-kategori dari skor C, yaitu : C, $\mathrm{C}_{\mathrm{n}}$,

$\mathrm{C}_{\text {des }}$ dan $\mathrm{C}_{\mathrm{sym}}$ 
Respon C (C murni), misal : jawaban "darah", menunjukkan :

1. Emosi tidak terkontrol yang patologis : meledak-ledak (eksplosif), agresif, emosi gampang diledakkan.

2. Skizofren.

3. Skizofren paranoid sebagaimana dibedakan dari neurotik.

4. Kemunduran yang bersifat organis.

5. Kecenderungan bunuh diri, seandainya saja respon demikian pertama kali muncul pada kartu VIII, IX, atau X.

6. Defisiensi mental berat, terutama deffect karena brain-injured.

7. Pada $\mathrm{S}$ anak-anak : gangguan emosional.

8. Hysteris.

9. Neurotic yang dibebani rasa cemas.

10. Orang-orang tak bertanggung jawab yang cenderung berbuat se-sukanya.

* Respon $\quad \mathrm{C}_{\mathrm{n}} \quad$ (Color naming), menunjukkan :

1. Kegagalan dari usaha individu untuk memanipulir / memanfaat-kan situasi 
emosional, karena penanganannya tidak realistik, aneh-aneh, atau magic.

2. Kepribadian patologis.

3. Pasien feeble-minded.

4. Anak-anak yang mengalami gangguan.

5. Mereka yang gampang bereaksi berlebihan oleh rangsang emo-sional yang walaupun nampak adanya usaha untuk mengendalikan emosinya, ternyata ia tidak dapat mengontrol afeknya secara efektif.

6. Skizofren dan kondisi organis.

7. Ada potensi untuk bertindak destruktif.

* Respon $\mathrm{C}_{\mathrm{des}}$ (Color description).

- Lebih baik daripada Cn, karena subyek hanya tidak bisa meng-gabungkan warnawarna menjadi konsep yang sudah ada tetapi bisa menghasilkan konsep yang lain dari warna tersebut, dan ini mencerminkan :

1. pendekatan individu yang sangat intelektual terhadap situasi emosional.

2. Mereka yang bisa dengan kuat digerakkan oleh rangsangan e-mosional dan tidak kuasa mengendalikannya, 
kontrol tidak memadai, akan tetapi mampu mensuspress ekspresi dari affek dan karenannya "outer control" bisa dianggap berhasil.

3. Kadang-kadang tampak seperti mengalami inhibisi berlebi-han dan reserved, diam, hati-hati.

4. Kemampuan menilai estetis

Bila penggambarannya berlebihan, menunjukkan :

$\rightarrow$ Subyek terlalu menekankan pendekatan intelektual didalam menghadapi situasisituasi yang mempengaruhi emosinya.

* Respon $\mathrm{C}_{\mathrm{sym}}$ (Color symbolism).

- Di sini subyek mendapatkan konsep yang tepat tetapi gagal menggabungkan aspek warna dan bentuk dari gambar yang disajikan.

- $\mathrm{C}_{\text {sym }}$ diartikan sama dengan $\mathrm{C}_{\mathrm{des}}$, kecuali bahwa :

1. $\mathrm{C}_{\mathrm{sym}}$ lebih menunjukkan adanya kecenderungan potensi intelek-tual dan 
keindahan (aestetik) yang lebih baik dibanding $\mathrm{C}_{\mathrm{des}}$.

2. Mereka sangat sensitif terhadap rangsangan emosional se-hingga affek menjadi sukar dikendalikan walaupun dalam hal inipun "outer control" bisa dianggap berhasil.

3. Pasien dengan kecenderungan histerik dan paranoid.

III.d.2. Skor Warna Achromatic : FC' ; CF' ; C'

* mean dewasa normal ; FC' $+\mathrm{C}^{\prime} \mathrm{F}+\mathrm{C}^{\prime}=1,1$

* Umumnya, penggunaan shading sebagai warna akromatik merupakan / mewakili respon yang dianggap "kurang berani" terhadap rangsang warna yang disajikan.

Oleh karena itu, munculnya respon-respon C' pada gambar, dan respon-respon kromatiknya cuma sedikit, menunjukkan :

- Adanya "toned-down", yaitu keragu-raguan didalam merespon rangsang-rangsang luar / eksternal. 
* Jumlah respon achromatic $\left(\mathrm{FC}^{\prime}+\mathrm{C}^{\prime} \mathrm{F}+\mathrm{C}^{\prime}\right)$ di atas rata-rata

1. Anxiety, apprehension (=perasaan takut) dan tension.

2. Kondisi depressive.

3. Menarik diri karena pengalaman traumatis atau apa yang di-sebut "burnt childreaction".

4. Perasaan ragu-ragu, tidak yakin, dan kehilangan harapan.

5. Menolak reaksi emosional atau reaksi emosional dangkal.

6. Pribadi yang arstistik dan peka.

7. Bila respon achromatic muncul tanpa disertai respon akroma-tik, dihubungkan dengan sikap ragu-ragu dalam memberikan respon terhadap rangsang yang datang dari lingkungannya.

8. Bila respon achromatic muncul sebagai addition terhadap res-pon chromatic berarti reaksi yang kaya dan bervariasi terhadap berbagai stimuli. 
9. Kontra-indikasi terhadap pelampiasan impuls.

10. Passivity and dysphoric moods, passivitas dan suasana hati yang suram, murung, putus asa, hilang semangat.

11. Ixothyme syndroms. Epileptoid personality.

12. Pada S anak-anak: Gangguan emosional.

13. Bila respon achromatic muncul bersamasama respon kromatik, dapat dinterpretasikan sama seperti untuk skor FC, CF dan C.

* Jumlah respon Achromatic rata-rata atau nol.

1. Kepribadian normal dan kadang-kadang juga berarti kepriba-dian yang abnormal.

2. Kemungkinan mengalami hambatan yang kaku dalam meng-ekspresikan diri.

3. Kecenderungan bunuh diri.

* Kualitas respon achromatic di atas rata-rata

1. Kontrol ego adekuat terhadap suasana hati yang murung, suram.

* Kualitas respon akromatik 
1. Kontrol terhadap suasana hati yang murung, suram tidak ade-kuat.

\section{Skor Content}

* Pada umumnya, skor-skor content mengungkap :

- Sifat dan luasnya minat pada individu.

- $\quad$ (kadang-kadang juga mengenai) bidang yang menjadi minatnya.

* Mean dewasa normal : $\mathrm{A}=9,4 ; \mathrm{Ad}=1,6 ; \mathrm{H}=3,2$; $\mathrm{Hd}=1,2$ A\% : batas kelaziman $20 \%-35 \%,(\mathrm{~A}+\mathrm{Ad}) \%=$ $46 \%$, titik kritis $50 \%$

* Variasi content dianggap optimum bila terdiri dari : $\mathrm{A} \%=20-35 \%$; dan $25 \%$ kategori kontent selain H, Hd, A dan Ad. ; dan sisanya terdiri dari kategori content H, Hd dan Ad.

* Kategori konten

1. Kategori konten yang dipergunakan cukup banyak dan sangat bervariasi artinya : minat cukup luas, intelegensi tinggi/pandai.

2. Kategori konten yang dipergunakan hanya sedikit bisa berarti : repressi, konstriksi (penyempitan), 
anxiety, intelligensi rendah, rigid, skizifren, sebab organis, prognosa organis, prognosa jelek.

3. Hanya dipergunakan satu kategori konten berarti : mental defective dan kondisi skizofren.

\section{III.1. A dan Ad}

* Content yang cenderung ke A (A+Ad) banyak dan beberapa kategori content lain-nya sedikit terdapat pada :

- Individu yang intelegensi menengah, atau intelegensi kurang.

* Jumlah respon A di atas rata-rata

1. Pola berpikir yang stereotip.

2. Anxiety.

3. IQ rendah atau mental - age rendah.

4. Paucity of interest, minat terbatas

5. Tingkah laku immature

6. Usia lanjut

7. Defens bercorak repressif, konstriktif atau submissive confor-mity, menyesuaikan diri dengan cara patuh.

8. Social distanciation : memelihara jarak, menjauhkan diri dari lingkungan sosial. 
9. Pada S dewasa : kondisi skizofren terutama bila A\% > 50\%.

10. Neurose, kemungkinan cenderung ke arah obsessive-compulsive

11. Pribadi psikopat dan paranoid.

12. Kondisi depressive.

13. Guardedness, sikap berhati-hati.

14. Pada $\mathrm{S}$ anak-anak : gangguan emosional bila A\% melebihi $70 \%$.

15. Respon terhadap psikoterapi kurang atau tidak memuaskan.

* Respon A jauh di bawah normal atau nol

1. Kondisi skizofren, terutama bila hanya sedikit atau tidak keluar binatang yang besar.

2. Pada $S$ dengan intelligensi superior : sehat atau terganggu.

3. Orang yang tidak punya pendirian tetap, yang sikapnya tidak bisa diduga dan yang tidak patuh terhadap atau tidak menuruti adat atau norma-norma sosial.

* Respon A yang tidak lazim 
1. Binatang yang dilihat saling membelakangi mencirikan : kemungkinan cenderung homoseksual.

2. Binatang yang buas dan ganas, seperti misalnya singa, harimau, macan, mencirikan : cenderung bersikap berani, tegas atau agresif, namun demikian $\mathrm{S}$ berusaha atau mencoba mengendalikannya.

3. Passive domestic animal / binatang peliharaan yang jinak men-cirikan : insecurity, perasaan tidak aman, tidak mantap, gelisa, dan sikap dependent.

4. Konten spider/laba-laba mencirikan: hubungan yang tidak serasi dengan figur ibu.

5. Katak mencirikan : kemungkinan gangguan dalam hal makan, misal anorexis (tidak ada nafsu makan), atau compulsive eating.

\section{III.2. Konten $\mathrm{H}$}

* Jumlah Konten $\mathrm{H}$ di atas rata-rata

1. Self-concept positif, perasaan dilukai minimum.

2. IQ tinggi. 
3. Hypercritical person, orang yang suka mengkritik.

* Jumlah Konten H di bawah rata-rata (terutama bila $\mathrm{H}$ hilang)

1. Empati sangat kurang atau tidak ada empati.

2. Social isolation atau membatasi diri (=tidak leluasa) dalam hu-bungan interpersonal.

3. Tidak bisa mengendalikan impuls secara sadar.

4. Pada protokol dengan $H$ tanpa $M$ : kemungkinan terapi tiba-tiba berhenti karena taraf intelligensi rendah atau latar belakang intelektual kurang, anxiety yang menonjol atau inhibisi yang kuat.

5. Immature, perasaan mudah dilukai dan kemungkinan perasaan ragu-ragu dalam memainkan sex-role.

6. Pada $\mathrm{S}$ anak-anak : gangguan emosional.

7. Kondisi skizofren dengan prognosa jelek.

* Jumlah Konten H rata-rata

1. Empati, minat dan sensitif terhadap orang lain. 
2. Pribadi normal, penyesuaian diri baik.

* Konten $\mathrm{H}$ yang aneh, tidak lazim

1. Respon $\mathrm{H}$ yang jenis kelaminnya tidak bisa diidentifikasi dengan jelas, mengelak untuk mengidentifisir jenis kelamin respon $\mathrm{H}$, atau apabila $\mathrm{S}$ menjadi bingung dalam menghadapi persoalan tersebut : kemungkinan homoseksual.

2. Konten $\mathrm{H}$ yang dilihat saling membelakangi : kemungkinan homoseksual.

\section{III.3. Konten AH}

1. Proses autistik, integrasi ego tidak baik, mungkin kecenderungan homoseksual.

2. Perasaan tidak senang dalam hubungan interpersonal.

III.4. Konten Hd

* Jumlah konten Hd rata-rata

1. Needs akan dependancy, ketergantungan. 
2. Kecenderungan menghindarkan diri dari interaksi sosial, me-ngarah pada isolasi sosial.

3. Anxiety yang bersangkut paut dengan hubungan interpersonal, sekalipun dalam hal ini $\mathrm{S}$ mempunyai minat dan cukup sensitif terhadap orang lain.

4. Kecenderungan homoseksual, terutama bila muncul konten "witches" (wanita sihir) atau "monster" (setan) pada lokasi D3 kartu X dan humanized animal (miki mouse/kartun) misal : Kelinci (Bugs) pada kartu V.

5. Kondisi skizofren.

6. Pada S anak-anak : gangguan emosional, terutama bila konten $\mathrm{Hd}$ yang muncul jumlahnya mencapai 2 x konten $\mathrm{H}$, dan kondisi epileptik.

* Jumlah Konten Hd diatas rata-rata

1. Anxiety, terutama social anxiety.

2. Defens intelektualisasi seperti misalnya yang ditemukan pada kasus kompulsif. 
3. Tidak mampu berhadapan dengan orang lain secara efektif.

4. Kecenderungan bersikap bermusuhan dan suka mencela yang karenanya $\mathrm{S}$ menghadapi hubungan yang didasari empati.

5. Reactive-depressive dan suicidaltendencies, depresif reaktif dan kecenderungan untuk bunuh diri.

6. Pada $\mathrm{S}$ anak-anak : gangguan emosional, terutama bila konten $\mathrm{Hd}$ yang muncul jumlahnya mencapai 2 x konten $\mathrm{H}$, dan kondisi epileptik.

* Jumlah konten Hd menyolok rendah atau nol

1. Dalam hubungan interpersonal tidak leluasa, membatasi diri.

2. Pada S anak-anak : problem emosional.

* Konten Hd yang tidak lazim

1. H tanpa kepala :

Kesukaran yang menyangkut aspek intellektual dalam hubungan interpersonal dengan kecenderungan ke arah tingkah 
laku agresif yang lebih primitif atau kemungkinan cenderung homoseks.

2. Respon genetik (kelamin atau yang berhubungan dengan kela-min) mencirikan bahwa :

$S$ tetap berada pada tahap pregenital sexuality (periode autoerotic yang mendahului object-love, atau hasrat yang tak disadari dari S dewasa neurotik untuk auto-erotic satisfaction) yang disertai kegagalan dalam hubungan heteroseksual atau kecenderungan ke arah homoseksual.

3. Payudara :

Mencirikan adanya frustasi yang berpangkal pada need akan afeksi atau dependancy needs, terutama frustasi yang berkaitan dengan need akan afeksi dari ibu.

4. Mulut :

Mencirikan frustasi berhubungan dengan dependency needs, boleh jadi bersamasama tindakan balasan sikap bermusuhan. * Penekanan pada mulut : 
- dihubungkan dengan alkoholisme dan neurotic depressive.

* Detail mulut, lubang mulut yang muncul bersama-sama dengan anal detail (detail bertalian dengan dubur) :

mencirikan kemungkinan

homoseksual.

5. Anal detail :

mencirikan kecenderungan obsessivecompulsive atau neuras-thenic atau homoseksual.

6. Anus (dubur) atau pantat/bokong, bila diasosiasikan dengan mata yang menatap dengan tajam :

mencirikan kecenderungan paranoid.

7. Wajah dilihat dari muka :

dihubungkan dengan perasaan curiga pada skizofren paranoid.

8. Anggota badan, tungkai dan lengan (yang muncul dengan dilatar-belakangi oleh kepekaan terhadap keutuhan image keseluruhan tubuh) : 
mencirikan self-reassurance, perasaan tentram/menentramkan diri, yang sebenarnya adalah kompensasi terhadap ketakutan akan dilukai orang lain.

9. Mata :

mencirikan paranoid, termasuk $\mathrm{S}$ normal yang penuh kecurigaan dan $\mathrm{S}$ dengan kecenderungan homoseksual.

10. Telinga : mencirikan kecenderungan paranoid.

\section{III.5. Konten Nature dan_Landskap}

Konsep respon yang berhubungan dengan nature $(\mathrm{Na})$, alam, dan : lanskap, pemandangan alam, serial views, pemandangan dari udara, sunset (matahari terbenam), sungai, dan danau $\rightarrow$ bila hal-hal tersebut diungkapkan sebagai bagian dari pemandangan (scenery).

* Content yang cenderung ke nature / alam, anatomi atau art / seni, mewakili : Adanya minat khusus

- Adanya sifat defensive

* Konten Nature (Na)

1. Pada $\mathrm{S}$ normal : intelligensi superior. 
2. Perasaan inferior.

3. Perasaan ditolak, tak disukai, karena figur ibu yang kikir, tidak memberi, mengekang.

4. Perasaan tidak berguna, tidak mampu, tidak berdaya dalam menghadapi kekuatan yang besar.

5. Pada $\mathrm{S}$ anak-anak : mungkin kecenderungan ke arah psikopat.

* Water Landscapes

1. Alkoholisme.

2. Perasaan malas, lamban, tidak berdaya, tidak mampu, tidak berguna, tidak efektif.

3. Kecenderungan dependency.

4. Perasaan tidak aman, tidak mantap, terisolasi, terpencil, dan depresi.

5. Pada S laki-laki : seksual tidak adekuat, tidak cakap, tidak mampu.

* Cliff, Cayon atau Chasm Landscape

(= Jurang, karang yang terjal, ngarai, tebing, celah / retakan bumi). 
1. Perasaan ditolak atau desersi, membelot, meninggalkan.

2. Menekan perasaan kesendirian dan perasaan gelisah, tidak mantap, tidak aman.

* Mountain dan Hilly Landscape

1. Perasaan inferior

2. Pada $\mathrm{S}$ pasien mental : perasaan takut.

3. Kebutuhan akan dependency yang tidak terlaksana, tidak kesampaian atau tidak disadari.

III.6. Konten Anatomi (At)

* Jumlah respon At di atas rata-rata

1. Kecenderungan hypochondriasis dan keluhan tidak enak badan pada umumnya seperti yang banyak dijumpai pada mereka yang dalam kondisi maladjusment, tidak dapat menyesuaikan diri, dan neurosis.

2. Impuls agresif dan destruktif yang tidak dikehendaki / ditakuti S. 
3. Kontra indikasi dari rasa permusuhan atau impuls destruktif yang dilampiaskan atau dinyatakan secara terbuka.

4. Defens atau pamer intellektual.

5. Anxiety.

6. Pada S dalam perawatan / rehabilitasi : sikap narsistik yang makin kuat yang mencirikan kondisi yang makin baik.

7. Mungkin kecenderungan homoseksual.

8. Kepribadian epileptik.

9. Kondisi psikosomatik.

10. Pada S usia lanjut : kondisi senile.

11. Alkoholisme dan skizofren.

* Respon Neural Anatomy

1. Perasaan waswas / takut jangan-jangan suatu ketika bakal terluka atau dilukai.

2. Lazim pada $S$ yang mendapat pendidikan di bidang kedokte-ran (medicine) atau bidang lain yang dekat atau bersangkut paut dengan bidang kedokteran.

* Respon Tulang / Anatomi keras

1. Bila hanya sedikit : normal.

2. Psikosomatik. 
3. Usaha mengendalikan rasa permusuhan dengan represi dan reaksi-formasi dengan maksud untuk menyangkal kehadiran impuls-impuls bermusuhan tadi.

4. S dengan profesi di bidang kedokteran / medis.

* Respon Visceral / Anatomi lembut / Jeroan

1. Sikap permusuhan yang dinyatakan terbuka secara verbal.

2. Sikap permusuhan yang seringkali dilampiaskan terhadap figur ibu, dengan tingkah merengek atau ngomel-ngomel.

3. Imature.

4. Psikopat.

* Respon Gusi atau gigi

1. Sikap agresif, terutama perasaan benci / dendam terhadap anak-anak dan sibling, yang asal-usulnya berkembang dari frustasi berhubungan dengan dependency needs.

2. Perasaan berdosa karena mastrubasi.

3. Kondisi skizofren.

4. Pada $\mathrm{S}$ anak-anak : sibling rivalry. 
* Respon Crude anatomy

(Respon anatomi disertai ekspresi kasar, rasa jijik, ngeri, dsb.)

1. Skizofren.

2. Anxious, perasaan khawatir, cemas, gelisah, cenderung ke phobia.

* Respon Anatomi yang canggih

(Respon anatomi yang digambarkan dengan bagus, misalnya : penampang melintang tulang belakang, foto rontgent).

1. Intellektual, umumnya normal, sebagian neurotik, jarang-jarang psikotik.

2. Anxiety dan sikap bermusuhan : dalam hal ini sikap bermusuhan biasanya disamarkan dalam bentuk kritik yang tajam atau bentuk ofensif verbal yang lain.

\section{III.7. Art dan design content}

1. Intelligensi superior.

2. Pola hidup dan dalam bidang estetis tidak mudah puas, pilih-pilih, sangat kritis, berperasaan lembut.

3. Hati-hati dan mengelak. 
4. Pada S laki-laki : minat dan polah tingkah laku kewanita-wanitaan, mungkin kecenderungan homoseksual.

5. Tidak mampu menghadapi masalah.

\section{Skor Populer - Original (P-O)}

Respon-respon yang $\mathrm{P}-\mathrm{O}$, mewakili fakta tentang :

$\rightarrow$ Kemampuan subyek didalam memandang dunia sekitarnya.

IV.1. Respon P

* $\mathrm{P}=$ cara memandang dunia sama dengan kebanyakan orang.

* P, diharapkan muncul 3 dari 10 jawaban $\mathrm{P}$ (populer) yang ada.

* Jumlah P wajar sampai $25 \%$, batas kritis $50 \%$, dan pada $\mathrm{S}$ dengan intelligensi superior diharapkan $0=2 \mathrm{P}$

* Dari jumlah respon yang adekuat (20 - 45

$\%$ ) diharapkan keluar 5P

* jawaban P yang wajar sebanyak 5P, sedangkan batas kritis $8 \mathrm{P}$

* Bila P muncul banyak (8 atau lebih) : 
menunjukkan adanya kebutuhan untuk bisa sama (cara memandang dunia) dengan orang lain, didorong oleh needs untuk berpendapat sama seperti pendapat umum..

* Bila P muncul sedikit berarti :

subyek tidak melihat dengan cara yang sama dengan yang dipakai orang lain.

(dengan kata lain, punya cara tertentu didalam memandang dunia).

* Bila P tidak muncul :

(walaupun sudah testing-the-limit) menunjukkan kalau subyek sangat lemah pemahaman terhadap realitas (ikatan dengan realitas lemah/longgar), dan bisa dianggap sebagai keadaan yang serius. (dengan kata lain, sangat tidak realistis).

\section{IV.2. Respon $\mathrm{O}$}

* $\mathrm{O}=$ memandang dunia sekitarnya dengan cara yang berbeda dengan yang dilakukan oleh kebanyakan orang lain.

* Jawaban O diperlukan untuk mengevaluasi kemampuan intellectual. 
* Bila Respon O berkualitas baik (FLR baik), berarti :

ada kecenderungan kemampuan superior dan original.

$(\mathrm{O}=2 \mathrm{P}$, pada $\mathrm{P}>5 \underline{\text { dan }}$ ditambah $\mathrm{O}$ additional $=2 \times \mathrm{O}$ main $)$

* Terlalu banyak $\mathrm{O}(\mathrm{O}>50 \%)$ berarti : subyek memiliki cara berpikit yang sangat tidak menentu, aneh-aneh.

* Bila O - muncul, berarti : lemahnya reality-testing subyek.

* O additional :

Munculnya respon $\mathrm{O}$ merupakan indikator paling bisa dipercaya kalau $S$ memiliki kemampuan superior, menghasilkan sesuatu yang orisinil dengan tetap berpegang pada hal-hal yang jelas, yang nyata.

\section{E. Skor FLR}

* Skor yang diperoleh merupakan dasar terpenting untuk memperkirakan :

- Taraf intelektual dan berfungsinya intelektual individu. 
* Hipotesa :

- Nilai FLR tertinggi, mengindikasikan kapasitas (capasity) intelektual yang dimiliki individu.

- Rata-rata FLR, menunjukkan taraf efisiensi intelektual umumnya.

- FLR minus mewakili :

a. Berfungsi intelegensi sangat rendah.

b. Kurang realistis.

\section{F. Skor Additional}

* Skoring additional diperkirakan merupakan :

- Indikator kapasitas yang dimiliki individu yang belum terwujud karena berbagai sebab.

* Dalam jumlah banyak, menunjukkan :

- kecenderungan superioritas individu.

\section{VII.2. INTERPRETASI untuk PROPORSI}

\section{KUANTITATIF}

Interpretasi untuk skoring gabungan antara beberapa kategori yang dihubungkan dengan skoring gabungan beberapa kategori lainnya. Interpretasi ini meliputi : 


\section{A. Proporsi yang berkaitan dengan Inner Resource dan}

\section{Impuls Life}

* Syaratnya :

- jumlah skor M minimal 3.

$\rightarrow$ Bila skor M kurang dari 3, maka penjelasan di bawah tidak bisa digunakan.

A.1. $\mathrm{M}: \mathrm{FM}$ (dengan $\mathrm{M}>2$ dan $\mathrm{FM}>0$ )

* Bila skor M lebih besar dari 2, \& melebihi skor FM (FM harus $>0)$ :

- Kebutuhan akan pemuasan diri dengan segera dapat ditunda, dan dialihkan pada nilai-nilai individu lainnya. Ini biasanya meru-pakan tanda adanya kematangan, karena individu menunjukkan adanya kemampuan untuk membedakan pemuasan diri tanpa adanya inner-conflict yang luar biasa.

* Bila skor FM lebih besar dari 2 dan sama dengan skor $\mathrm{M}$ :

- Ini menunjukkan seseorang yang menerima dorongan-dorongan-nya dengan siap sebagai individu yang matang.

* Bila skor M lebih besar dari 2 tetapi kurang dari

1,5 skor FM : 
- Individu lebih diperintah / diatur oleh kebutuhan-kebutuhan yang segera (mendesak) akan pemuasan dirinya daripada oleh tujuan jangka panjang. Ini merupakan pertanda belum matang.

* Bila skor M lebih dari 2 dan berada diantara 1 1,5 skor FM

(misal : $\mathrm{M}=4$ dan $\mathrm{FM}=5,6$, atau 7) :

- Perbandingan ini patut mendapat perhatian khusus. Perimbangan ini sering dijumpai di dalam suatu batas normal, dan menunnjukkan bahwa pemuasan diri yang instinctif lebih penting daripada nilai diri.

- Hipotesa-hipotesa mengemukakan bahwa perbandingan skor $\mathrm{M}$ : FM akan mengalami perubahan, terutama bila dihubungkan dengan perbandingan skor FC : CF. Misal :

$\rightarrow$ Impulsivitas (sifat individu yang selalu menuruti kata hati) ditunjukkan bila skor FM lebih besar dari 2M. Tetapi hal ini baru jelas bila skor CF melebihi skor FC. Ini berarti, individu cenderung untuk bertindak di luar dorongannya. 
* Di lain pihak, bila ada skor M sebanyak 2 x FM tetapi respon skor CF tidak dominan :

- Ini tidak dapat dikatakan bahwa individu cenderung untuk bertindak di luar dorongannya. Kombinasi ini dapat menunjukkan : ketidakmatangan dalam membentuk rencana kerja dan tingkah laku sosial yang dapat diterima.

* Bila skor M dan FM keduanya sedikit menunjukkan :

- Individu mungkin tertekan (jika F\% -nya tinggi)

- Kelemahan ego individu (jika FLR-nya sedang atau rendah)

A.2. $\mathrm{M}:(\mathrm{FM}+\mathrm{m})$

* Bila $(\mathrm{FM}+\mathrm{m})$ lebih dari 1 dan 1,5 x nya $\mathrm{M}$ (misal : $\mathrm{FM}+\mathrm{m}=7$ atau lebih dan $\mathrm{M}=4$ ) :

- Ini menunjukkan adanya ketegangan yang sangat kuat, yang membawa individu untuk menggunakan inner-resources nya secara konstruktif. 
(skor m menunjukkan kemungkinan ada konflik atau ketegangan)

* Bila skor M hampir sama atau sedikit lebih besar dari $(\mathrm{FM}+\mathrm{m})$, dan skor $\mathrm{m}$ tidak lebih dari 1 atau 2:

- Implikasinya adalah bahwa individu mempunyai kontrol yang cukup terhadap dorongan hidupnya untuk kestabilan dirinya.

\section{B. Proporsi Yang Berkaitan Dengan Responsivitas Emosional Terhadap Lingkungan \\ B.1. Sum C (jumlah C)}

* Menunjukkan tingkah reaktivitas subyek terhadap stimulus dari luar, baik yang terkontrol ataupun tidak.

a. Reaktivitas yang normal terhadap stimulus emosional membutuhkan sum $\mathrm{C}$ sekurangkurangnya $=3$.

b. Bila sum $\mathrm{C}$ kurang dari 3 :

- Sangat sedikit sekali responnya terhadap pengaruh lingkungan.

B.2. $\mathrm{FC}:(\mathrm{CF}+\mathrm{C})$ 
* Bila FC melebihi $(\mathrm{CF}+\mathrm{C})$, tetapi skor $(\mathrm{CF}+\mathrm{C})$ masih diwakili oleh beberapa respon :

- Individu dapat menggunakan kontrol terhadap dorongan-dorongan dan emosinya.

- Biasanya individu dapat memberikan respon secara murni dengan perasaan dan tindakannya bersama-sama terhadap lingkungan sosialnya.

* Bila $(\mathrm{CF}+\mathrm{C})$ tidak ada, atau sangat sedikit :

- Terdapat suatu kontrol yang sangat besar, sehingga respon sosialnya (FC) menjadi dangkal / hanya permukaan saja.

- Kualitas dari tipe respon warna (C) yang bermacam-macam (yaitu : F $\mathrm{C}$, atau F/C, atau $\mathrm{C} / \mathrm{F}$, dsb) dapat dipakai untuk mengarahkan hipotesa-hipotesa ini.

* Bila $(\mathrm{CF}+\mathrm{C})$ melebihi FC :

- Suatu tanda kontrol yang lemah terhadap dorongan emosionalnya.

B.3. Prosentase Respon-respon Kartu VIII, IX, dan X (sebagai warna murni)

* Banyaknya respon terhadap 3 kartu terakhir ini menunjukkan : 
- Respon umum terhadap rangsangan emosional dari lingkungan.

Ini mungkin diekspresikan dalam tingkah laku yang dapat diobservasi dan mungkin juga tidak.

* Bila jumlah respon diatas $40 \%$ dari jumlah semua respon :

- Diduga bahwa individu mudah terangsang oleh lingkungannya.

* Bila jumlah responnya kurang dari 30\% :

- Individu kurang responsif.

- Individu mungkin dihambat oleh kondisi

lingkungan yang kuat.

B.4. Perbandingan reaction-time Kartu Kromatik Akromatik

* Bila rata-rata reaction-time kartu kromatik lebih besar dari kartu akromatik, lebih dari 10 detik :

- Ini menunjukkan bahwa individu terganggu oleh stimulus emosional yang kuat.

* Apabila individu terganggu oleh kartu-kartu yang mengandung shading (kartu IV, VI, VIII), dan menunjukkan waktu reaksi yang lain, berarti : 
- Gangguan akan terjadi bila rangsanganrangsangan dari luar menyinggung kebutuhan afeksi.

$\Rightarrow$ Hendaknya hati-hati dalam menganalisa reaction-time pada setiap kartu, sebab :

Reaction-time yang lama dapat diakibatkan oleh adanya aspek warna (color) atau bayangan (shading).

\section{Proporsi yang berkaitan dengan Keseimbangan Introversive - Extratensive}

Dalam hubungannya dengan penggunaan Ro, maka orang yang dinamakan :

a. Introversive :

- Seseorang yang memiliki fungsi imaginasi yang berkembang baik, termasuk didalamnya : fungsi fantasinya, tujuan jangka panjangnya, maupun dorongan-dorongan dalam diri yang diakuinya. Sedangkan responsivitas dan keterlibatannya dengan dunia luar sesuai dengan nilai-nilai dan kebutuhan-kebutuhannya sendiri. 
- Orang introversive yang punya penyesuaian diri yang baik biasanya tidak menarik diri dan tidak mudah mundur. Ia orang yang dapat berdiri sendiri.

b. Extratensive:

- Seseorang yang tinggi responsivitasnya terhadap lingkungan, ekspresi emosionalnya berlebihan, punya perasaan / pribadi yang hangat, tidak merubah dunia seperti yang diingininya.

- Orang Extratensive yang punya penyesuaian diri yang baik / well-adjusted, reaksinya tidak pasif. Ia kreatif dalam hubungannya dengan obyek dan manusia di luar dirinya, dan ia berusaha untuk mencapai tujuan yang telah ia rencanakan. (dkl, ada keseimbangan).

\section{C.1. M : Sum C}

* Keseimbangan antara jumlah skor M dan jumlah skor C menun-jukkan :

- Banyaknya seseorang dirangsang dari dalam

dan dari luar.

* Bila skor M lebih besar dari 2, dan melebihi jumlah skor $\mathrm{C}$, dan skor $\mathrm{C}$ tidak $=0$ :

- Individu cenderung lebih yakin kepada innernya daripada kepada lingkungannya. 
* Sebaliknya, adalah sum C melebihi M.

C.2. $(\mathrm{FM}+\mathrm{m}):\left(\mathrm{Fc}+\mathrm{c}+\mathrm{C}^{\prime}\right)$

- Respon (FM+m) menunjukkan : tendensi introversive.

- Respon akromatik menunjukkan : tendensi extratensive.

* Bila perbandingan ini menunjukkan hal yang sama dengan perbandingan $M$ : Sum C :

- Individu masih akan mengalami perubahan dalam perkem-bangannya.

* Banyak hal yang tergantung pada : skor mana dalam perbandingan tersebut, yang mendapat penekanan. Misal :

- Penekanan pada skor m atau skor c akan membawa ke arah hipotesa mengenai : kecemasan yang muncul dari kebutuhan akan rasa ketergantungan (need for dependancy).

- Penekanan pada skor C' : dapat menunjukkan adanya depresi dan kemunduran.

C.3. Prosentase respon kartu VIII, IX, dan X 
* Bila perosentase respon ketiga kartu terakhir ini berlangsung pada arah yang sesuai dengan ciri / tanda dari introversive-extratensive :

- Menunjukkan bahwa arah dari keseimbangan masih seperti biasa-nya.

\section{Proporsi yang berkaitan dengan Pengorganisasian} Kebutuhan- Kebutuhan Afeksi

D.1. $(\mathrm{FK}+\mathrm{Fc}): \mathrm{F}$

* Ratio optimal dari FK + Fc terhadap F akan dapat terjadi bila :

- $(\mathrm{FK}+\mathrm{Fc})$ jumlahnya mendekati $1 / 4$ hingga $3 / 4$ skor F. Misal : bila $2 \mathrm{FK}$ dan $4 \mathrm{Fc}$, dan $\mathrm{F}$ berkisar antara $8-24$. ini menunjukkan :

$\rightarrow$ Individu memiliki respon yang sehat terhadap manusia, tidak terlalu sensitif ataupun terlalu tergantung.

* Bila FK + Fc kurang dari 1/4 F :

- Ada kecenderungan untuk menolak atau merepress atau kurang berkembangnya kebutuhan akan afeksi, yang dapat menjadi gangguan besar didalam adjustment pada umumnya. 
* Bila FK + Fc melebihi 3/ $4 \mathrm{~F}$ :

- Ada kecenderungan bahwa kebutuhan akan afeksi dan respon / umpan balik dari orang lain terlalu besar dan membahayakan bagian kepribadian yang lain.

D.2. Perbandingan Skor Shading Undifferentiated dengan yang Differenti-ated :

* Bila skor-skor shading yang Undifferentiated (yaitu : K,KF,k,kF,c dan $\mathrm{cF}$ ) jumlahnya lebih banyak daripada skor shading yang Differentiated (yaitu : $\mathrm{Fc}, \mathrm{Fk}$ dan $\mathrm{FK}$ ) mengindikasi adanya :

- Kebutuhan afeksinya sulit diintegrasikan di dalam kepribadian.

D.3. Perbandingan Skor Kartu Akromatik dengan Kartu Kromatik :

* Bila respon kartu akromatik $\left(\mathrm{Fc}+\mathrm{C}^{\prime}+\mathrm{c}\right)$ lebih besar daripada respon kartu kromatik $(\mathrm{FC}+\mathrm{CF}+\mathrm{C})$ dengan perbandingan $2: 1$, maka : 
- Tampaknya pengalaman individu dengan stimulus luar telah demikian traumatis sehingga menimbulkan ketakutan.

* Sebaliknya, bila respon kromatik ternyata $2 \mathrm{x}$ respon akromatik :

- Kemampuan untuk mengadakan interaksi dengan lingkungan sosial adalah optimum.

* Bila $(\mathrm{CF}+\mathrm{C})$ lebih besar dari FC, dan keduanya melebihi skor kartu akromatik dengan perbandingan $2: 1$ atau lebih :

- Individu cenderung untuk bertindak di luar emosinya.

\section{E. Proporsi yang berkaitan dengan Minat Intelektual dan}

\section{Ambisi}

E.1. Jumlah Respon (R)

* Jumlah seluruh respon biasanya (tidak selalu) menunjukkan :

- Kemampuan produksi individu. Orang yang lebih intelejen / pandai biasanya lebih produktif. 
- Jumlah respon rata-rata dari orang dewasa yang normal antara $20-45$

* Jumlah respon yang sedikit menunjukkan :

- Tidak adanya produktifitas, karena terbatasnya kemampuan, atau karena gangguan emosional.

* Jumlah respon yang banyak menunjukkan :

- Produktifitas yang kaya dari seseorang.

- Adanya suatu kebutuhan untuk kompulsif yang benar.

\section{E.2. $\mathrm{W}: \mathrm{M}$}

* Perbandingan ini menunjukkan : besarnya ambisi intelektual individu.

* Bila W : M mendekati 2 : 1, dan W-nya baik menunjukkan :

- Adanya potensi kreatif yang cukup untuk memperkuat dorongan nyata ke arah achievement / pencapaian prestasi intelektual.

* Perbandingan 2 : 1 dianggap optimal, dengan syarat : respon $\mathrm{M}$ minimal 3 dan respon $\mathrm{W}$ mendekati 6 .

* Bila W lebih besar dari $2 \mathrm{M}$, menunjukkan :

- Taraf aspirasi individu terlalu tinggi. 
Perubahan hipotesa ini perlu dilihat dari FLR.

* Bila M kurang dari $2 \mathrm{M}$, menunjukkan :

- Individu memiliki potensi kreatif, tetapi tidak mendapatkan jalan untuk penyalurannya / pemuasannya.

E.3. $(\mathrm{H}+\mathrm{A}):(\mathrm{Hd}+\mathrm{Ad})$

* Perbandingan ini menunjukkan tingkat kekritisan individu.

Jumlah skor H dan A diharapkan mendekati 2 x jumlah skor Hd dan Ad.

* Bila $(\mathrm{H}+\mathrm{A})$ kurang dari 1,5 (Hd+Ad) :

- Ada kecenderungan ke arah eksak, kritis dan terlalu teliti. Kecenderungan ini bisa dihubungkan dengan adanya : kecemasan .

E.4. A\% (persentase skor animal)

* A\% Menunjukkan :

- Tingkat stereotip pada cara berpikir individu.

* Makin tinggi A\%, pada umumnya :

- Cara berpikir subyek makin biasa / cara berpikir sehari-hari. Makin sempit minatnya / interesnya.

* Persentase optimal dari A\% adalah $20-35 \%$. 
* A\% di atas 50\% dihubungkan dengan :

- Kapasitas intelektual yang rendah.

- Adanya penyesuaian diri yang terganggu.

E.5. Rata-rata waktu respon (respon time)

* Waktu rata-rata yang diperlukan seseorang untuk setiap respon, menunjukkan :

- Kecepatan persepsi individu.

* Makin cepat reaksi mental individu, maka :

- Ada kecenderungan individu untuk lebih siaga / alert.

* Rata-rata respon time diatas 1 menit :

- Menunjukkan proses mental yang lamban.

Kelambanan didalam bereaksi dapat

disebabkan oleh karena :

$\rightarrow$ Rendahnya kapasitas mental.

$\rightarrow$ Adanya depresi emosional.

* Rata-rata respon time yang kurang dari 30 detik

- Tergolong cepat, dan mungkin dipaksakan.

F. Proporsi yang berkaitan dengan Kontrol dalam keadaan terdesak 


\section{(Constrictive - Control)}

* Dua faktor yang berhubungan dengan kontrol adalah :

- $\mathrm{F} \%$ dan $(\mathrm{FK}+\mathrm{F}+\mathrm{Fc})$

Interpretasi $\mathrm{F} \%$ telah dikemukakan (lihat F\% sebelumnya)

* Setiap skor F menunjukkan bahwa :

- Efektivitas kontrol individu dalam bahaya. Hal ini karena kelemahan dalam reality-testing.

* $(\mathrm{FK}+\mathrm{F}+\mathrm{Fc}) \%$ merupakan indikasi lain dari kontrol individu bila dalam keadaan terdesak.

- Rage normalnya antara 50-75\%.

- Bila persentasenya diatas $75 \%$ :

$\rightarrow$ Diduga adanya neurotic constriction, karena kurangnya spontanitas emosional.

* Bila $\mathrm{F}$ dan mendekati $50 \%$, tetapi $(\mathrm{FK}+\mathrm{F}+\mathrm{Fc}) \%$-nya tidak lebih dari 75\%, menunjukkan bahwa :

- Individu dapat dikontrol dan dikekang, tetapi masih dapat hidup dengan menyenangkan orang lain.

* Faktor kontrol lainnya ; adalah

$\mathrm{M}:(\mathrm{FM}+\mathrm{m})$ dan $(\mathrm{FC}+\mathrm{CF}+\mathrm{C})$.

- Keterangan lihat halaman depan. 


\section{G. Evaluasi terhadap Kontrol, Potensi-Potensi Dalam (Inner Resources), Pendekatan Intelektual Dan Level Intelektual}

Pada bagian ini kita mempelajari hubungan antara skor-skor dalam record secara lebih kompleks. Contoh : ratio $\mathrm{M}$ : Sum $\mathrm{C}$ sudah merupakan sesuatu yang berarti, tetapi interpretasi yang lebih mendalam masih dapat dilakukan bila ratio tersebut dipandang dalam hubungannya dengan $\mathrm{F} \%$.

Sebuah grafik yang berisikan distribusi dari skor-skor determinant (main scores maupun additional scores), yang disebut psikogram, dalam sekali padang dapat menyajikan informasi yang diperlukan untuk mengevaluasi suatu determinant atau membandingkan sekelompok determinant satu sama lainnya.

Hipotesa sebelumnya yang diperoleh dari skor atau ratio skor individu yang menyangkut faktor-faktor penting seperti kontrol dan derajat spon-tanitas dapat diperiksa melalui hubungan-hubungan yang lebih mendalam.

Sebelumnya, suatu skor lokasi, rata-rata FLR atau jumlah dari respon original dipergunakan sebagai dasar untuk membuat hipotesa tentang cara pendekatan 
intelektual individu dan untuk mengevaluasi tingkat inte-lektualnya.

Hipotesa-hipotesa awal ini dapat diperiksa lagi dengan melihat hubungan-hubungan diantara semua skor lokasi dan di antara skor-skor lainnya, baik secara kuantitatif maupun secara kualitatif yang berhubungan dengan fungsi intelektual.

\section{Psikogram}

Penampang terpenting dalam psikogram yang harus diamati adalah bentuk dari skor-skor determinan utama (main scores). Apakah kebanyakan dari responrespon itu cenderung berkumpul di tengah, di sayap kiri atau di sayap kanan, atau apakah keseluruhannya terbagi secara merata di ketiga daerah itu?

$\rightarrow$ Penilaian semacam ini akan menghasilkan pengertian awal tentang ke-seimbangan diantara ketiga cara mempersepsi :

a. Jika persepsi subyek lebih banyak dipengaruhi oleh daya ima-jinasinya, kebutuhan-kebutuhan dan dorongan-dorongannya sendiri responrespon akan terpancang pada sayap kiri dari grafik, 
b. Jika persepsi subyek lebih banyak dipengaruhi oleh stimulus-stimulus dari luar dirinya, respon-responnya akan terpancang pada sisi kanan dari grafik,

c. Jika persepsi subyek cenderung rasional, impersonal, tidak emo-sional respon-responnya cenderung untuk terpusat di tengah-tengah grafik.

Sebagai ilustrasi :

Seorang laki-laki dewasa (HS), sehat, tingkat intelegensi yang rata-rata atau sedikit di atas rata-rata. Dalam tes Rorschach ia memberi 25 respon sebagai berikut : 3M, 4FM, 1 additional m, tidak ada k, 1FK, 9F, 2FC, tidak ada c, tidak ada C', 3FC, 2CF dan tidak ada $\mathrm{C}$.

$\rightarrow$ Record ini memperlihatkan suatu distribusi skor yang seimbang.

- Skor F- nya seperti yang diharapkan $(\mathrm{F} \%=36)$, terdapat beberapa skor $\mathrm{Fc}$ dan $\mathrm{FK}$, dan ratio $(\mathrm{FK}+\mathrm{Fc}): \mathrm{F}=3: 9 \rightarrow$ memperlihatkan kontrol yang baik, tidak kaku.

- Sayap kiri Psikogram hubungan antara M : FM adalah $3: 4, \rightarrow$ memuaskan. Tidak tampak 
adanya perasaan-perasaan yang tidak adekuat terhadap dirinya dan tidak ada ketegangan (additional $\mathrm{m}=1$ ). Terdapat $\mathrm{K}=1$ bisa diabaikan. Untuk menginterpretasikan faktor ini kita harus melihat pada kartu berapa respon K diberikan.

- Sayap kanan Psikogram memperlihatkan juga bahwa orang ini responsif, cukup spontan, tanpa kehilangan kontrol, termasuk orang yang bisa menyesuaikan dirinya dengan baik. Ratio perbandingan antara $M:$ Sum $C=3: 31 \frac{1}{2}$ dan $(\mathrm{FM}+\mathrm{m}):\left(\mathrm{Fc}+\mathrm{c}+\mathrm{C}^{\prime}\right)=4: 2$, menggambarkan seseorang yang secara bersamaan dipengaruhi baik oleh dorongan-dorongan dari dalam diri maupun dari dunia nyata. Tidak ditemukan adanya tanda-tanda "anxiety" (tidak ada skor c, $\mathrm{k}$ dan C'). Tidak ada skor additional bisa diasumsikan bahwa individu dapat menggunakan potensi-pontesi dirinya secara baik.

Perlu diperhatikan juga skor FLR, munculnya respon FC dan $\mathrm{CF}, \mathrm{M}, \mathrm{H},(\mathrm{H})$ atau (A), sehingga bisa digambarkan secara lebih spesifik status intelektual subyek (FLR), perasaannya terhadap manusia lain (M) 
dan kekhasannya dalam menyesuaikan diri dengan lingkungan sosial (FC dan $\mathrm{CF})$.

2. Cara Pendekatan ( Manner Of Approach)

Pemeriksaan terhadap penyebaran skor lokasi memperlihatkan cara khas seseorang dalam mengadakan pendekatan terhadap persoalan hidup sehari-hari. Ada orang yang :

a. memilih mengobservasi sesuatu dengan sangat teliti terhadap detil dengan mengabaikan kesimpulan umum, (mengutamakan $\mathrm{D}$ dan $\mathrm{d}$, tapi kurang memperhatikan W).

b. memulai pendekatan terhadap masalah dengan mengadakan survei secara umum dulu baru kemudian beralih memperhatikan detil (memulai W dulu dilanjutkan $\mathrm{D})$.

c. langsung mengambil kesimpulan, dengan memberi respon yang meng-gunakan lokasi W tetapi tidak tegas.

Sedangkan (HS) di atas, tidak memperlihatkan cara pendekatan khusus :

$\rightarrow$ skor-skor lokasinya terbagi sebagai berikut : $28 \%$ (W), 56\% (D), $12 \%$ (d), dan 4\% (dd), ada 1 additional $\mathrm{W}$. Hal ini menggambarkan bahwa : 
cara pendekatan orang ini tampaknya meperlihatkan kemampuan untuk lebih melihat secara umum tanpa terlalu memperhatikan kenyataan. Juga ada kemampuan untuk memperhatikan hal-hal kecil secara khusus, tetapi tidak dalam tingkat yang mengganggu fungsi intelektualnya.

Analisa terhadap kualitas respon (terutama responrespon $\mathrm{W}$ ) diperlukan untuk menentukan bagaimana kapasitas-kapasitas ini diintegrasikan, apakah kemampuan untuk memperhatikan detil itu dipergunakan untuk membangun keseluruhannya. Sedangkan FLR dari W, D dan d akan memungkinkan interpreter untuk mengamati kualitas pendekatan intelektual individu secara khusus.

3. Perkiraan Level Intelektual

Evaluasi terhadap level intelektual harus menggunakan pertimbangan faktor-faktor : (1) FLR, (2) jumlah dan kualitas respon-respon M, (3) jumlah dan kualitas respon W, (4) jumlah dan kualitas respon O, (5) variasi dari Content, dan (6) Succession (jajaran).

\subsection{FLR}


Untuk mengevaluasi kapasitas dan efisiensi intelektual penting diperhatikan :

1. FLR setiap respon

2. Rata-rata FLR setiap skor lokasi dan determinant

3. penyebaran FLR

4. Average unweigted dan weigted FLR

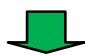

- FLR 4.0 menunjukkan kapasitas intelektual yang very superior, FLR 3.0 kapasitas superior dan FLR 2.0 kapasitas rata-rata atau sedikit di atas rata-rata, FLR 1.0 atau kurang menunjukkan kapasitas di bawah rata-rata atau kapasitas inferior, tetapi jika skor content dari respon memiliki FLR rendah akan memberikan gambaran tentang kesulitan-kesulitan fungsi intelektual.

- Seseorang yang hanya memperlihatkan skor individual dengan penyebaran FLR yang sedikit (nilai FLR rata-rata sama) maka secara intelektual berfungsi lebih tenang, daripada seseorang yang FLR nya memperlihatkan nilai minus dan nilai 
superior sekaligus. Jika terjadi perbedaan dalam rata-rata nilai FLR untuk beberapa jenis kategori skoring, maka kategorikategori skoring yang menujukkan nilai ekstrim perlu diperhatikan.

- Average unweighted FLR dan average weighted FLR lebih penting dari FLR dalam respon individu.

$\rightarrow$ Jika kedua average FLR itu berada dalam "range" yang sama, maka perbedaan antara kapasitas dan efisiensi dapat diperkirakan kecil. Tetapi perbedaan yang cukup jauh diantara kedua nilai tersebut akan menjadikan tanda bahwa ada gangguan efisiensi intelektual.

- Average weighted FLR 1.0 - 1.4 memperlihatkan kapasitas inte-lektual yang rata-rata atau di atas rata-rata. Sedangkan antara 1.5 - 1.9 yang berisikan FLR 2.5 dalam jumlah cukup banyak untuk mengkompensasikan FLR 1.0 atau lebih rendah, menunjukkan kapasitas intelektual 
yang superior. Nilai average yang 2.0 atau lebih menunjukkan kapasitas intelektual very superior, terutama jika terdapat nilai FLR 2.5 setiap nilai FLR yang interior.

Berikut ringkasan estimasi taraf intelektual :

a. Menghitung kapasitas Intelektual dengan cara :

1. Skor FLR tertinggi yang bisa dicapai testee dari seluruh skor FLR di 10 kartu, Average Weighted FLR :

\begin{tabular}{|c|l|}
\hline FLR tertinggi & \multicolumn{1}{|c|}{ Indikasi } \\
\hline$\geq 4,0$ & Very Superior \\
\hline $3,0-3,5$ & Superior \\
\hline $2,0-2,5$ & Sedikit di atas rata-rata \\
\hline 1,5 & Rata-rata \\
\hline$\leq 1,0$ & Di bawah rata-rata \\
\hline
\end{tabular}

2. Skor Average Weighted FLR, kemudian masukkan dalam kategori taraf intelektualnya :

\begin{tabular}{|c|l|}
\hline $\begin{array}{c}\text { Average } \\
\text { Weighted FLR }\end{array}$ & \multicolumn{1}{c|}{ Indikasi } \\
\hline$\geq 2,0$ & $\begin{array}{l}\text { Very Superior, kalau ada } \\
\text { cukup FLR 2,5 atau lebih }\end{array}$ \\
\hline $1,5-1,9$ & $\begin{array}{l}\text { Superior, kalau ada cukup } \\
\text { FLR 2,5 atau lebih }\end{array}$ \\
\hline $1,0-1,4$ & $\begin{array}{l}\text { Rata-rata atau lebih } \\
\text { tinggi dari rata-rata }\end{array}$ \\
\hline$\leq 1,0$ & Inferior \\
\hline
\end{tabular}


b. Menghitung efisiensi intelektual dengan cara :

1. Skor Average Unweighted FLR, kemudian masukkan dalam kategori taraf intelektualnya :

\begin{tabular}{|c|l|}
\hline Average Unweighted FLR & \multicolumn{1}{|c|}{ Indikasi } \\
\hline$\geq 2,0$ & Very Superior \\
\hline $1,5-1,9$ & Superior \\
\hline $1,0-1,4$ & Rata-rata \\
\hline$\leq 1,0$ & Inferior \\
\hline
\end{tabular}

3.2. Jumlah dan kualitas respon $M$

- Semakin banyak respon M dengan semakin baik kualitasnya dibandingkan dengan respon-respon pada umumnya, makin cerdaslah fungsi intelektual subyek.

- Kurangnya respon M dalam rekord yang tergolong superior, yang berisikan $\mathrm{W}$ yang baik dan nilai FLR tinggi tidak mengurangi derajat superioritasnya. Kekurangan responrespon $\mathrm{M}$ memper-lihatkan adanya gangguan yang serius dalam efisiensi intelektual.

3.3. Jumlah dan kualitas respon $\mathrm{W}$

Tingginya tingkat fungsi intelektual diperlihatkan dengan sejumlah respon $\mathrm{W}$ yang 
jelas dan berkualitas baik, sebab hal itu berarti ting-ginya akurasi (kecermatan), spesifikasi dan organisasi dari respon $\mathrm{W}$.

Banyaknya respon-respon $\mathrm{W}$ yang tidak tegas (tidak terdiferen-sisasi) menunjukkan adanya :

(1) kapasitas intelektual yang rendah, atau

(2) gangguan emosional terhadap efisiensi.

Kurangnya respon W dalam rekord yang memiliki respon D yang baik menunjukkan adanya pendekatan yang sangat berhati-hati dan bukan karena kurangnya kapasitas intelektual.

3.4. Jumlah dan kualitas respon $\mathrm{O}$

- Respon O yang berkualitas baik (FLR tinggi) yang diberikan se-bagai respons utama maupun additional respons dalam jumlah banyak menunjukkan efisiensi intelektual dalam tingkat yang tinggi.

- Respon O yang kacau menunjukkan adanya gangguan serius dalam fungsi intelektual, tetapi tidak selalu menunjukkan kapasitas intelektual yang rendah. 
- Perbandingan FLR dengan jumlah responrespon $\mathrm{O}$ memberikan gambaran tentang efisiensi, yaitu bagaimana individu memanfaatkan kapasitas mentalnya.

Sebagai contoh, FLR yang dengan O yang tidak banyak :

$\rightarrow$ dapat menunjukkan bahwa seseorang memiliki intelegensi tinggi namun dia tidak kreatif atau tidak kaya potensi.

\subsection{Variasi Content}

- Subyek dengan kemampuan superior biasanya paling sedikit memberikan $25 \%$ respon diluar kategori $\mathrm{H}, \mathrm{Hd}$, A dan $\mathrm{Ad}$, dan mengeluarkan paling sedikit 3 kategori content yang lain.

$\rightarrow$ Pengeluaran content semacam ini memperlihatkan fleksibilitas minat yang menunjang efisiensi intelektual.

$\rightarrow$ Respon-respon A dalam jumlah banyak (yang merupakan respon termudah) menunjukkan tingkat intelegensi yang sedang atau kurang 
3.6. Succession (jajaran)

Succession ditentukan oleh susunan pemberian skor lokasi.

Berikut indikasi yang bisa diperoleh dari suksesi adalah :

\begin{tabular}{|l|l|}
\hline \multicolumn{1}{|c|}{ suksesi } & \multicolumn{2}{|c|}{ indikasi } \\
\hline 1. Rigid & $\begin{array}{l}\text { Keterbatasan dalam effisiensi } \\
\text { intelektual karena menggunakan } \\
\text { pendekatan yang sama untuk } \\
\text { berbagai situasi, tanpa } \\
\text { mempertimbangkan perlunya } \\
\text { pendekatan baru karena adanya } \\
\text { aspek-aspek baru. }\end{array}$ \\
\hline 2. Orderly & $\begin{array}{l}\text { Fungsi intelektual optimum karena } \\
\text { adanya sistematika dalam mendekati } \\
\text { situasi baru dengan tetap luwes } \\
\text { (fleksibel didalam menggunakan } \\
\text { pendekatan sesuai situasinya., } \\
\text { karena mamp memanfaatkan } \\
\text { pengalama masa lalunya untuk saat } \\
\text { itu. }\end{array}$ \\
\hline 3. Loose & $\begin{array}{l}\text { Kontrol intelektual lemah, karena } \\
\text { cara pendekatan pada satu situasi } \\
\text { sangat berbeda dengan pendekatan } \\
\text { pada situasi lain, dan tidak ada } \\
\text { kesinambungannya. }\end{array}$ \\
\hline 4. & $\begin{array}{l}\text { Indikasi sama dengan suksesi } \\
\text { "Loose", tetapi lebih parah, karena } \\
\text { control intelektual terganggu / kacau }\end{array}$ \\
\hline
\end{tabular}

Untuk memperkirakan tingkat intelektual secara valid, interaksi antara ke 6 aspek yang telah 
dijelaskan seperti tersebut di atas harus dipertimbangkan.

\section{H. Analisa Urutan (Sequence Analysis)}

Sequence analysis terdiri dari pemeriksaan kartu per kartu atau pemeriksaan respon per respon. Disini tidak ada hipotesa interpretasi yang baru. Penggunaan sequence analysis adalah terutama untuk menguatkan, mengubah atau menggugurkan hipotesa interpretasi dasar sebagi aspek dinamis yang dituntut oleh pekerjaannya. Tingkah laku testee, bahasa yang dipergunakan subyek dan kualitas-kualitas khusus dari percikan tinta diperhitungkan di sini.

Pemakaian metoda sequence analysis tidak mudah untuk dijabarkan karena sifat pendekatan ini dinamis dalam menginterpretasikannya. Hanya kerangka umum dari metoda ini akan diuraikan di sini, yaitu :

1. perlu diketahui setiap jenis respon yang ditimbulkan oleh setiap kartu. Pengetahuan tentang kartu dan respon-respon khusus yang ditimbulkannya akan memungkinkan tersedianya standard untuk menilai pekerjan subyek.

2. Skor lokasi harus diperiksa dalam hubungannya dengan succession, organisasi dan hubungannya 
dengan percikan tinta. Seperti juga pemeriksaan terhadap determinat yang harus memperhatikan succession, hubungan dengan materi percikan, lokasi dan content.

Beberapa gambaran tentang kepribadian subyek yang dapat diungkapkan melalui sequence analysis ini dapat dilihat berikut :

a. Setiap respon pertama bagi setiap kartu perlu diperhatikan. Reaksi awal yang diharapkan adalah memberikan respon $\mathrm{W}$ pada setiap kartu. Jika subyek memberikan respon $\mathrm{W}$ sebagai respon pertama untuk sebagian besar kartu tetapi tidak untuk semua kartu, maka arti dari kondisi semacam ini perlu diperhatikan.

b. Determinan yang dipergunakan bagi setiap respon pertama juga bermak-na merefleksikan kesiapan subyek untuk menggunakan potensi-potensi tertentu. Contoh :

$\rightarrow$ Subyek yang cenderung memberikan $\mathrm{F}$ sebagai respon pertama, kemudian diikuti $M$ atau FC atau Fc. Keurutan ini memberikan gambaran sebagai kontrol yang menghambat, tetapi kemudian diikuti 
oleh relaksasi setelah subyek merasa tenang. Pengaruh kartu berwarna atau bernuansa (shading) terhadap keurutan determinan perlu diperhatikan sebagai pertimbangan terakhir.

3. Jumlah respon-respon yang diberikan pada setiap kartu dapat meng-arahkan interpreter pada jenis material yang mendorong atau menghambat bagi subyek.

Penolakan untuk memberikan suatu respon terhadap suatu kartu mem-punyai bermacam-macan makna seperti juga kartu yang ditolak.

- Kartu IX adalah kartu yang paling sering ditolak, bahkan juga oleh orang-orang normal.

- Kartu II, IV dan VI juga sering ditolak.

- Kartu-kartu lain biasanya ditolak oleh orang-orang yang memperlihat-kan pertahanannya pada kualitas kartu secara khusus.

- Penolakan terhadap 4 kartu lebih oleh subyek yang berusia di atas 7 tahun menunjukkan adanya gangguan kepribadian yang serius.

4. Variasi FLR dari kartu ke kartu dan dari respon ke respon perlu diperhatikan 
- FLR yang lebih rendah dari biasanya dapat memberikan tanda pada dinamika gangguan kepribadian, jika gangguan itu muncul.

5. Variasi dalam reaction time dan respon time dari kartu ke kartu harus diperhatikan.

Perhatikan bagaimana faktor waktu ini berhubungan dengan material percikan tinta, dengan lokasi, determinan dan content.

- Waktu istirahat yang lama bisa memberikan tanda adanya kesulitan tertentu.

- Waktu reaksi yang memanjang terhadap kartu-kartu berwarna atau terhadap kartu-kartu ber-shading perlu diamati.

6. Urutan reaksi terhadap warna di kartu-kartu II, III, VIII, IX dan $\mathrm{X}$ serta terhadap semua kartu bershading, terutama kartu IV dan VI sangat penting sekali. Ada 3 pertimbangan yang dapat dipergunakan untuk menganalisa warna dan shading ini :

a. Apakah warna dan shading ini dipergunakan sebagai determinan?

b. Jika warna dan shading tidak dipergunakan atau hanya diper-gunakan sedikit sekali, bagaimana bentuk reaksi terhadap warna dan shading itu? 
Apakah daerah berwarna atau ber-shading diingkari walaupun respon yang diberikan mengarah pada pemakaiannya

c. Apakah terdapat bukti-bukti adanya gangguan sebagai akibat warna dan shading? Gangguan yang dimaksudkan di sini adalah apa yang disebut dengan color shock atau shading shock.

Perhatikan ilustrasi dibawah ini :

Seorang subyek (AN) memberikan respon yang baik, satu F dan satu M pada kartu I. Kemudian dia memilih area hitam pada kartu II (D3) dan kartu III (W), kedua-duanya F setelah menghabiskan waktu lebih dari satu menit untuk setiap kartu. Kemudian dia melanjutkan pemberian $\mathrm{W}$ dan $\mathrm{D}$ yang bagus bagi kartu IV, V, VI dan VII, beberapa diantaranya respon-respon $\mathrm{Fc}$, diikuti dengan respon anatomi untuk kartu VIII, IX dan $\mathrm{X}$ tapi di inquiry dia mengingkari penggunaan warna bagi responrespon anatominya. Subyek ini memperlihatkan penolakan, pengingkaran warna $\rightarrow$ menunjukkan adanya kesulitan dalam situasi-situasi yang merangsang secara emosional, ia seorang individu yang peka dan berjaga-jaga (alert). 
7. Perlu dibandingkan materi-materi yang berkembang selama inquiry atau testing the limit dengan yang dihasilkan di performance proper.

Hipotesa umumnya :

- performance proper menunjukkan potensi-potensi subyek yang sudah siap didayagunakan, sedangkan materi-materi additional yang berkembang dalam inquiry menunjukkan potensi-potensi yang baru didayagunakan setelah subyek semakin mapan dalam situasi tersebut. Penguraian terhadap main respon atau memberikan respon-respon additional yang spontan pada tahap berikutnya, dapat menunjukkan subyek mudah dipengaruhi atau subyek sudah tidak begitu defensif sehingga lebih mudah menggunakan potensi-potensi dirinya, atau subyek sudah merasa lebih rileks dalam menghadapi material dan si pemeriksa.

Ketujuh petunjuk di atas bisa dipertimbangkan hanya sebagai suatu pem-buktian terhadap kemungkinankemungkinan interpretasi yang ditawarkan oleh sequence analysis.

\section{Content Analysis}


Interprestasi Rorschach sampai saat ini masih menyandarkan diri terutama pada elemen-elemen struktural dari test, seperti jumlah $\mathrm{W}, \mathrm{M}, \mathrm{P}$ dan sebagainya. Aspek kualitatif dari respon-respon telah menjadi bagian yang integral dari proses-proses interpretasi sebagai hasil pekerjaan Klopfer dan Beck.

Content dari respon-respon yaitu apa yang subyek lihat dari materi percikan tinta merupakan faktor penting terakhir yang menarik perhatian pemakai-pemakai Rorschach. Analisa terhadap content dari respon-respon menawarkan tanda-tanda yang berhubungan dengan arti simbolik dari pembentukan konsep subyek.

Selain dilihat makna kuantitatifnya, content dari respon bisa dilihat makna kualitatifnya. Beberapa peneliti Rorschach, seperti Wheeler dan Lidner, berpendapat bahwa content dari respon tidak terlepas dari lokasi, misal respon "kepiting" yang populer pada kartu X tidak memiliki nilai signifikansi yang sama dengan "kepiting" pada daerah lain dikartu tersebut ataupun di kartu lain, serta content dipengaruhi oleh individunya dan bukan oleh stimulusnya. Harus berhati-hati memanfaatkan content yang diberikan di sini. 
Hipotesa-hipotesa yang disajikan di bawah ini dibuat berdasarkan teori kepribadian yang dinamis dan juga dari pengalaman-pengalaman klinis. Oleh karena itu, bagi pemula disarankan mempelajari lebih jauh interpretasi tentang content jika berminat memahami lebih akurat. Penyajian ini diberikan bukan sebagai fakta, tetapi sebagai hipotesa kinerja (dugaan) :

\section{Figur Manusia}

- Beberapa hal perlu dicatat dalam menganalisa figur manusia :

$\rightarrow$ Penekanan pada bagian-bagian tertentu pada tubuh dapat menunjukkan adanya beberapa persoalan atau kesulitan.

a. Pengulangan persepsi kepala dan wajah bisa menunjukkan adanya persoalan dalam intelektualitas, atau perasaan bahwa aktivitas biologis itu kurang bermanfaat dibanding aktifitas intelektual. Persepsi semacam ini sering ditemukan pada orang-orang yang menggunakan defens dalam bentuk intelektualisasi atau kompulsi. 
b. Persepsi profil-profil dapat menunjukkan bahwa individu tersebut ku-rang yakin terhadap dirinya maupun orang lain.

c. Orang-orang yang cenderung melihat bagianbagian dari tubuh yang secara langsung maupun tidak langsung berhubungan dengan makna seksual dapat diartikan dengan dua kemungkinan apakah dia ingin memperlihatkan bahwa dia cukup matang untuk memberikan respon semacam itu atau dia sedang berusaha untuk menutupi hubungan-hubungan seksual yang inadekuat.

Misalnya, telah ditunjukkan bahwa orang-orang yang paranoid seringkali melihat pantat dan bahwa orang-orang yang kekurangan dalam pemuasan oral yang infantil akan melihat payudara.

$\rightarrow$ Persoalan dalam identifikasi seksual sering tampak melalui content.

- Jika seorang subyek mengalami kebingungan seksual, dia mungkin akan tidak dapat menentukan apakah figur manusia yang dia lihat itu laki-laki atau perempuan. 
$\rightarrow$ Kegiatan-kegiatan yang dilakukan oleh figur manusia yang terlihat dapat diinterpretasikan.

a. Orang yang terlihat berkelahi, berdebat atau saling menyerang dapat memperlihatkan perasaan-perasaan bermusuhan dalam diri subyek.

b. Orang-orang yang terlihat sedang menundukan kepala, mendengar-kan atau berbicara dapat menjadi tanda dari perasaan-perasaan submissive dari subyek.

c. Orang yang tertawa, berdansa dapat merefleksikan kepuasan subyek pada saat ini atau memperlihatkan keinginan subyek untuk mendapatkan kepuasan.

d. Orang yang dilihat jelek, cantik atau sedang mengancam mungkin merupakan proyeksi dari perasaan subyek tentang orang-orang lain, walaupun perasaan-perasaan ini secara sadar direpres.

e. Jika figur manusia dilihat dalam bentuk tersamar seperti monster, badut atau setan, atau figur-figur mitos dan figur-figur dengan tingkah laku seperti binatang, dapat merupakan 
petunjuk bahwa individu tersebut tidak dapat mengidentifikasikan dirinya secara akrab dengan manusia yang sebenarnya.

f. Wanita sihir, misalnya, mempunyai makna yang signifikan untuk menunjukan kualitas hubungan antara ibu dan anak.

\section{Figur-figur binatang}

- Binatang-binatang dilihat oleh berbagai subyek dari usia-usia yang berbe-da, baik yang normal maupun yang abnormal. Respon-respon ini dapat menunjukan potensi teknik penyesuaian diri subyek.

- Arti dari mengamati berbagai jenis binatang agak spekulatif, tetapi bebe-rapa indikasi melihat :

a. binatang buas seperti seperti harimau dan singa dapat menujukkan adanya kecenderungan agresif tertentu pada individu yang dicobanya untuk diatasi melalui berbagai cara.

b. binatang pasif seperti sapi atau domba, dan binatang domestik seperti anjing / kucing, dapat menunjukkan adanya kepasifan dan sikap-sikap tergantung.

3. Respon-respon seksual 
- Respon seksual dapat terdiri dari 3 jenis :

1) respon-respon dengan simbol-respon seksual yang jelas seperti ular, patung-patung purba atau rumah

2) respon-respon yang diberikan pada area-area yang biasanya di-asosiasikan dengan respon-respon seksual seperti : daerah D bawah di kartu II, area D atas di kartu VI atau area d tengah bawah di kartu VII

3) respon-respon seksual langsung, seperti menunjukkan adanya mens-truasi, hubungan seks dan organ genetik.

- Makna dari respon-respon seksual harus dipelajari berkaitan dengan faktor-faktor lain dalam Rorschach, subyek yang bersangkutan dengan pengeta-huan yang diperoleh dari riwayat hidup subyek. Sebaiknya tidak menguraikan hanya berdasarkan respon seksual subyek saja. Harus dilihat apakah individu menghindari problem-problem seksual dengan cara menyebutkannya, apakah dia menghawatirkan adanya problem-problem seksual ?

4. Content Anatomi, (Konsep Ilmu Pengetahuan)

- Respon-respon anatomi, geografi atau science seringkali diberikan oleh individu-individu yang 
berusaha memperlihatkan intelektualitasnya. Ini merupakan suatu cara untuk menutupi perasaanperasaan mereka yang sebenarnya.

$\rightarrow$ Respon-respon semacam ini dapat menunjukkan perasaan kurang adekuat secara intelektual, terutama bila respon-respon yang diberikan menghindari setiap bentuk penjelasan yang akan menguraikan bentuk atau spesifikasi.

$\rightarrow$ Respon-respon semacam ini mengandung makna interpretasi yang sama walaupun respon-respon tersebut diberikan oleh spesialis-spesialis dalam bidang tersebut.

5. Content-content lainnya :

Topeng : adanya penekanan dalam permainan peran untuk menghindari sorotan terhadap pribadi.

Emblem (lencana) : menunjukkan sikap-sikap terhadap otoritas, terutama sikap-sikap yang submisif.

Laba-laba : dapat mengeluarkan sikap-sikap terhadap figur ibu.

Laba-laba dianggap merupakan lambang dari ibu yang jahat. 
Huruf alfabet / nomor-nomor : merupakan tanda adanya kondisi patologis, jika diberikan oleh orang dewasa.

Darah : respon-respon darah menjadi indikasi dari adanya reaksi-reaksi afeksif yang kuat dan tidak terkontrol.

Makanan : dapat menunjukan adanya kebutuhan untuk tergantung, keinginan untuk diurus oleh orang lain.

Gigi : dapat diinterpretasikan sebagai menggambarkan sikap penuh kekecewaan / agresif akibat adanya frustasi dari kebutuhan untuk tergantung.

Gusi : juga punya konotasi yang sama. Respon gigi lebih banyak diberikan oleh anak-anak dan remaja daripada orang dewasa.

Abstraksi : merefleksikan nada perasaan yang kira-kira hampir sama, suasana hati yang euphoric (gembira) bila memperlihatkan kemeriahan, atau musim semi, dan suasana hati yang dysphoric (muram) bila memperlihatkan kekacauan atau mimpi buruk. 
Respon-respon semacam ini biasanya merefleksikan intelegensi yang superior.

Catatan :

Disarankan membaca literatur tentang Interpretasi Tes Rorschach secara lebih mendalam, seperti pada buku Rorschach Interpretation : Advanced Technique, karangan Phillips, L. \& Joseph G. Smith, 1963. Grune \& Stratton, New York, USA.

\section{Kesimpulan}

Didalam membuat interpretasi sebaiknya digunakan gabungan interpretasi masing-masing kategori skor dengan interpretasi untuk proporsi kuantitatif.

Untuk mengetahui Inner Resource dan Impuls Life bisa menggunakan data : $\mathrm{M}: \mathrm{FM}, \mathrm{M}:(\mathrm{FM}+\mathrm{m})$,

Untuk mengetahui Responsivitas Emosional Terhadap

Lingkungan bisa menggunakan data : Sum C, FC : (CF +

C), Prosentase Respon-respon Kartu VIII, IX, dan X , Perbandingan reaction-time Kartu Kromatik - Akromatik.

Untuk mengetahui Keseimbangan Introversive Extratensive bisa menggunakan data : M : Sum C, $(\mathrm{FM}+$ $\mathrm{m}):\left(\mathrm{Fc}+\mathrm{c}+\mathrm{C}^{\prime}\right)$, Prosentase respon kartu VIII, IX, dan $\mathrm{X}$. 
Untuk mengetahui pengorganisasian kebutuhan afeksi bisa menggunakan data : $(\mathrm{FK}+\mathrm{Fc}): \mathrm{F}$, Perbandingan Skor Shading Undifferentiated dengan yang Differentiated, Perbandingan Skor Kartu Akromatik dengan Kartu Kromatik

Untuk mengetahui Minat Intelektual dan Ambisi bisa menggunakan data : Jumlah Respon (R), W : M , (H+ A) $:(\mathrm{Hd}+\mathrm{Ad}), \mathrm{A} \%$, Rata-rata waktu respon.

Untuk mengetahui kemampuan Kontrol dalam keadaan terdesak (Constrictive - Control) bisa menggunakan data : $\mathrm{F} \%$ dan $(\mathrm{FK}+\mathrm{F}+\mathrm{Fc}), \mathrm{M}:(\mathrm{FM}+\mathrm{m})$ dan $(\mathrm{FC}+\mathrm{CF}+\mathrm{C})$.

\section{Latihan soal :}

Seorang klien dites kepribadian dengan tes Rorschach, dan skor yang didapat :

a. skor lokasi : $\mathrm{W}=5 ; \mathrm{D}=10 ; \mathrm{d}=3 ; \mathrm{dr}=2 ; \mathrm{S}=3$

b. skor determinan : $\mathrm{M}=4 ; \mathrm{F}=12 ; \mathrm{Fc}=2 ; \mathrm{FC}=2 ; \mathrm{FC}=2$; $\mathrm{C}=1$

c. skor content : $\mathrm{H}=6, \mathrm{Hd}=2, \mathrm{~A}=4, \mathrm{Ad}=3, \mathrm{Obj}=4, \mathrm{Arch}=$ $2, \mathrm{~N}=1, \mathrm{At}=1$

d. skor $\mathrm{P}-\mathrm{O}: \mathrm{P}=5, \mathrm{O}=\mathrm{tdk}$ ada 
Dari data di atas buat interpretasi tentang :

1. Pengorganisasian kebutuhan afeksi

2. Kontrol saat dalam keadaan terdesak

\section{Referensi :}

Klopfer, B \& Davidson, H.H, 1962. The Rorschach Technique. An Introduction Manual. Harcourt, Brace, \& World, Inc., New York, USA.

Phillips, L. \& Joseph G. Smith, 1963. Rorschach Interpretation : Advanced Technique. Grune \& Stratton, New York, USA. 
146 |P a g e 